\title{
EXTRACTING RELIABLE PALEO-OCEAN TEMPERATURES AT SOUTHERN MID-LATITUDES DURING THE GREENHOUSE TO ICEHOUSE TRANSITION - A LA-ICP-MS STUDY OF THE TRACE ELEMENT CHEMISTRY OF EOCENE FORAMINIFERA FROM NEW ZEALAND
}

John Benjamin Creech

A thesis submitted to Victoria University of Wellington in partial fulfilment of the requirements for the degree of Master of Science with Honours in Geology

School of Geography, Environment and Earth Sciences Victoria University of Wellington

April 2010 


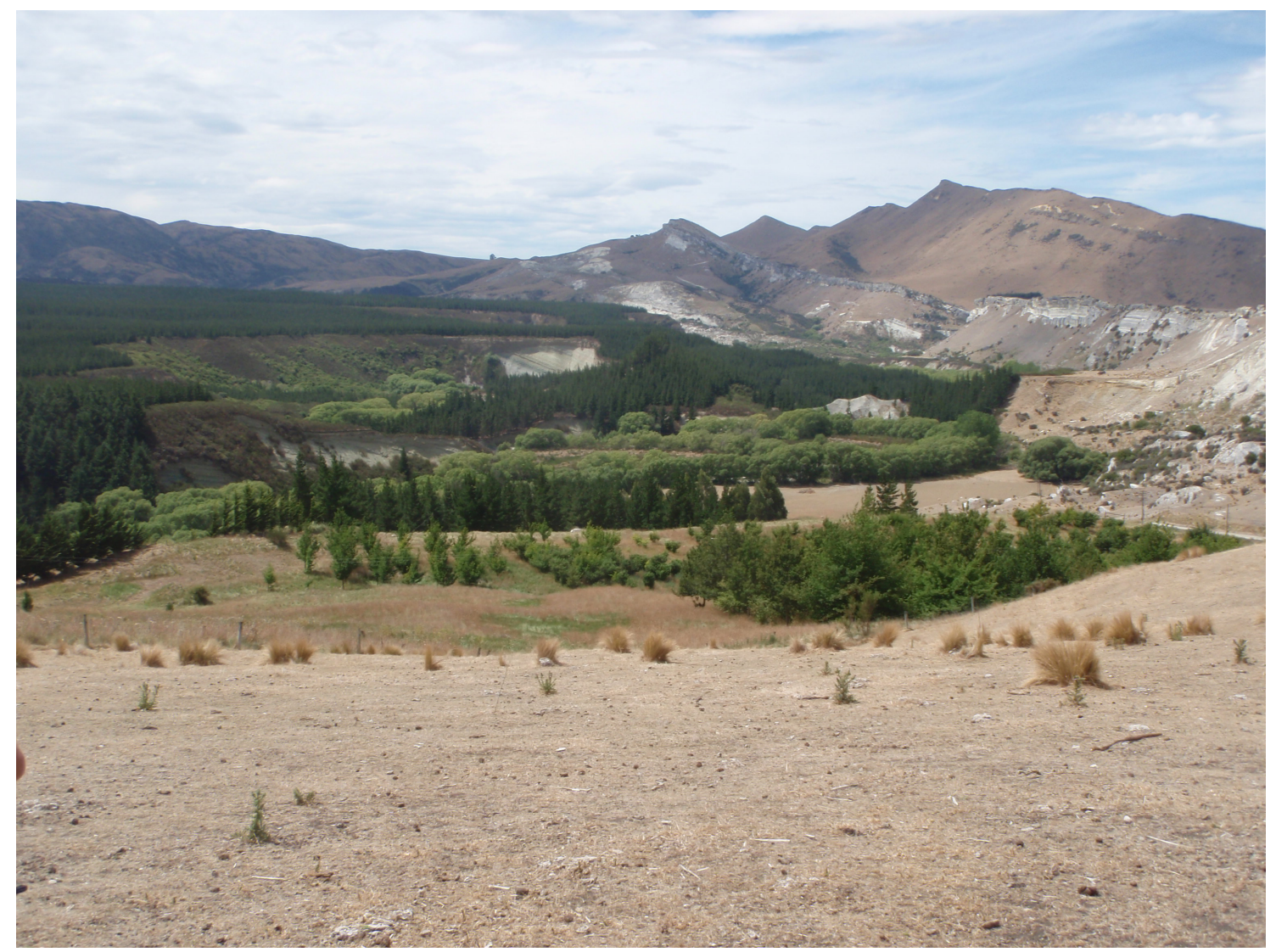

A view over the mid-Waipara River section, north Canterbury. 


\section{$\underline{\text { ABSTRACT }}$}

Laser ablation inductively coupled plasma mass spectrometry (LA-ICP-MS) has been used to measure in situ elemental ( $\mathrm{Mg}, \mathrm{Al}, \mathrm{Mn}, \mathrm{Zn}, \mathrm{Sr}, \mathrm{Ba} / \mathrm{Ca})$ ratios of 13 species of variably preserved early to middle Eocene planktonic and benthic foraminifera from the mid-Waipara River section, north Canterbury, New Zealand. The sediments from Waipara River were deposited at bathyal depths $(c a .1000 \mathrm{~m})$ on the northern margin of the east-facing Canterbury Basin at a paleo-latitude of $c a .55^{\circ} \mathrm{S}$. LA-ICP-MS analysis yields trace element depth profiles through foraminifera test walls that can be used to identify and exclude zones of surficial contamination and infilling material resulting from diagenetic coatings, mineralisation and detrital sediment. Screened $\mathrm{Mg} / \mathrm{Ca}$ ratios are used to calculate sea temperatures from late early to early middle Eocene ( $c a .51$ to 46.5 Ma), a time interval that appears to span the termination of the Early Eocene Climatic Optimum (EECO). During this time, sea surface temperatures (SST) varied from 30 to $24^{\circ} \mathrm{C}$ and bottom water temperatures (BWT) from 21 to $14^{\circ} \mathrm{C}$.

Comparison of $\mathrm{Mg} / \mathrm{Ca}$ sea temperatures with published $\delta^{18} \mathrm{O}$ and $\mathrm{TEX}_{86}$ temperature data from the same samples (Hollis et al., 2009) shows close correspondence, indicating that LA-ICP-MS can provide reliable $\mathrm{Mg} / \mathrm{Ca}$ sea temperatures even where foraminiferal test preservation is less than ideal. Agreement between the three proxies also implies that $\mathrm{Mg} / \mathrm{Ca}$ - temperature calibrations for modern planktonic and benthic foraminifera can generally be applied to Eocene species, although some species (e.g., V. marshalli) show significant calibration differences. The $\mathrm{Mg} / \mathrm{Ca}$ ratio of the Eocene ocean is constrained by our data to be $35-50 \%$ lower than the modern ocean depending on which $\mathrm{TEX}_{86}$ - temperature calibration is used to compare with the $\mathrm{Mg} / \mathrm{Ca}$ sea temperatures (Kim et al., 2008; Liu et al., 2009).

Sea temperatures derived from oxygen isotope analysis of foraminifera from midWaipara show amplified variability relative to the $\mathrm{Mg} / \mathrm{Ca}$ and $\mathrm{TEX}_{86}$ derived temperatures. While this difference might be attributed to the oxygen isotopes being more susceptible to diagenetic effects, the data may be consistent with the growth and collapse of significant global ice sheets during cool periods in the Eocene on timescales of $c a$. 0.5 Myr. The timing of the termination of the EECO in the reconstructed climate record from mid-Waipara is consistent with other published climate records (Tripati et al., 2003, 2005; Zachos et al., 2008). 
A large decrease in foraminiferal $\mathrm{Mn} / \mathrm{Ca}$ ratios up the mid-Waipara section is observed with the youngest samples having $\mathrm{Mn} / \mathrm{Ca}$ ratios similar to modern foraminifera. This does not appear to be a diagenetic fingerprint as foraminiferal preservation is generally poorer up-section. Global cooling following the EECO may have led to enhanced biological productivity and uptake of $\mathrm{Fe}$ and $\mathrm{Mn}$, thereafter producing an ocean with Mn concentrations more similar to the present ocean. This hypothesis is consistent with that proposed to explain changes in the thallium isotope ratios of $\mathrm{Fe}$ and $\mathrm{Mn}$ crusts observed at this time (Nielsen et al., 2009). 


\section{ACKNOWLEDGEMENTS}

Firstly, I would like to thank my supervisors. Joel Baker (VUW), thank for your help with this work and for always maintaining high standards. It's sometimes been a fight for your time, but when you give it the results are always impressive and valuable. I hope you are pleased with the end result. Chris Hollis, Hugh Morgans and Erica Crouch (GNS), thank you for your guidance and input into this work. I really enjoyed the field work/trips to the south island, and the opportunity to get to know you and others on those trips. The CBEP meeting was a great experience - if only I had the chance to talk to those people again at this end of my thesis.

Thank you to my family, who have always supported and encouraged me, and always knew I was capable of this even when I didn't. I hope I've made you proud. Dad, I don't think you'll be able to carry this round and show it to everyone like you did with that radio interview. Mum, I owe you a huge debt to for looking after Jackson so many times so I could work on my thesis. He's lucky to have such a loving granny. To Jackson, thank you for always being so cheery when you said 'bye daddy' when I had to go to work, and always so excited to see me when I picked you up. You're such a good little boy, and so clever that you'll surely understand all of this in a year or two. To my darling Jess, thank you for all your love and support and for putting up with me working all the time and occasionally being a grouch (and everything else). You make me feel so lucky, and I promise to do the same for you when you're working on your thesis.

There are a number of other people I would like to thank that directly or indirectly contributed to this project: Rich Pancost and Matt Huber, who are part of the wider group of collaborators on this project, and both of whom made helpful suggestions and comments at some point or another. Euan Smith who helped me battle with statistics. Julene and Netty who battled bugs alongside me, giving me people to ask questions or just complain to. Peter Barrett for the conversations about Eocene ice sheets. John Patterson and Richard Wysoczanski for helping me with the old microprobe. I would also like to acknowledge the VUW academic staff in general. It was the quality of the people here that made me want to stay and work here in the first place.

I would like to acknowledge my peers, both from my undergraduate and postgraduate years. I have made some great friendships that have made uni life really enjoyable, and I hope will remain in the years to come. I particularly have to mention Kim, Martin, Jules, Rach, Boots, George, Thor, Dan, Hannu and Gretta, Netty, Aidan and Julene and kids, Sam, Keely and Shano, but there are many more great people. I also must mention my oldest buddy Dave, who always lent an interested ear.

Finally, I would like to thank VUW for providing a strategic research grant that funded my travel to the Goldschmidt meeting in Switzerland, and the Stewart Charitable Trust for the J.L. Stewart Postgraduate Scholarship. 


\section{TABLE OF CONTENTS}

1. INTRODUCTION 1

1.1 General Introduction 1

1.2 Thesis Structure and Outline 2

1.3 Climate in the Greenhouse World 3

1.3.1 Paleogene Climate 4

1.3.2 Atmospheric $\mathrm{CO}_{2}$ record 8

1.3.3 Cenozoic Ice Volume 9

1.3.4 Outstanding Problems 10

1.4 Paleoclimate Proxies 11

1.4.1 Mg/Ca Paleothermometer 12

1.4.2 Oxygen Isotopes 23

1.4.3 TEX $86 \quad 26$

1.4.4 Other Proxy Information 28

1.5 Sample Material 29

1.5.1 The Mid-Waipara River Section 31

1.5.2 Foraminifera ecology 40

2. METHODS 41

2.1 Sample Preparation 41

2.1.1 Foraminifera Separation 41

2.1.2 Foraminifera Cleaning and Mounting 41

2.2 LA-ICP-MS Trace Element Analysis 42

2.3 Data Processing 43

2.3.1 Trace Element Depth Profiles 43

2.3.2 Data Screening 46

2.4 Paleotemperature Determinations 48

2.4.1 Mg/Ca Temperature Parameters 48

3. EOCENE SEA TEMPERATURES FOR THE MID-LATITUDE SOUTHWEST PACIFIC FROM MG/CA RATIOS IN PLANKTONIC AND BENTHIC FORAMINIFERA

$\begin{array}{ll}\text { Abstract } & 50\end{array}$

1. Introduction $\quad 51$

2. Samples and Existing Comparative Data 53 
3. Analytical Techniques

3.1 Sample preparation $\quad 57$

3.2 LA-ICP-MS trace element analysis 58

3.3 Data reduction and screening 59

3.4 Calculating Mg/Ca paleotemperatures 61

4. Results 62

4.1 Comparative analyses of 13 species from three samples of the mid-Waipara section 62

4.2 Trace element/Ca analysis of 5 species from throughout the mid-Waipara section 66

4.3 Changes in Mg/Ca paleotemperatures through the mid-Waipara section $\quad 68$

5. Discussion 70

5.1 Do the Mg/Ca temperatures reliably record past sea temperatures? $\quad 70$

5.2 Implications for the seawater Mg/Ca ratio in the Eocene ocean 75

$\begin{array}{ll}5.3 \text { Comparison with oxygen isotope data } & 78\end{array}$

5.4 Cenozoic changes in the redox state of the ocean revealed through foraminiferal Mn/Ca ratios? 80

5.5 Implications for global climate 83

6. Conclusions 85

$\begin{array}{ll}\text { References } & 86\end{array}$

4. SUPPLEMENTARY RESULTS AND DISCUSSION 87

$\begin{array}{lll}4.1 & \text { Introduction } & 87\end{array}$

4.2 $\mathrm{Mg} / \mathrm{Ca}$ Paleothermometry by LA-ICP-MS 87

4.2.1 Comparison of Foraminifera Species for LA-ICP-MS analysis 87

4.2.2 Inter-species Calibrations 89

4.2.3 Interpretation of Additional Trace Element Data 90

4.2.4 LA-ICP-MS Cleaning Procedures 92

$\begin{array}{lll}4.2 .5 & \text { Summary } & 93\end{array}$

4.3 The Role of $\mathrm{CO}_{2}$ in the Greenhouse to Icehouse Transition 93

5. CONCLUSIONS 96

5.1 Conclusions 96

$\begin{array}{lll}5.2 & \text { Suggestions for future work } & 97\end{array}$

$\begin{array}{ll}\text { 6. REFERENCES } & 100\end{array}$

7. APPENDICES 118 


\section{LIST OF FIGURES}

\section{Chapter 1.}

Figure 1.1. New Zealand geological timescale for the Paleogene (after Cooper, 2004).

Figure 1.2. Cenozoic climate $\left(\delta^{18} \mathrm{O}\right)$, carbon isotope $\left(\delta^{13} \mathrm{C}\right)$ and $p \mathrm{CO}_{2}$ data for the period 0 to 65 million years, adapted from Zachos et al. (2001) and Zachos et al. (2008).

Figure 1.3. Cenozoic ice volume reconstruction from Lear et al. (2000). 10

Figure 1.4. $\mathrm{Mg} / \mathrm{Ca}$-temperature calibration curves.

Figure 1.5. Primary reservoirs and paths of $\mathrm{Ca}$ and $\mathrm{Mg}$ transfer at the Earth's surface (from Wilkinson and Algeo, 1989).

Figure 1.6. $\mathrm{Mg} / \mathrm{Ca}$ of seawater over time from various proxy and model data, adapted from Lowenstein et al. (2001) and Dickson et al. (2001)

Figure 1.7. Graphical illustration of the sensitivity of temperature reconstructions (y-axis) to seawater $\mathrm{Mg} / \mathrm{Ca}$ ratios (x-axis) at 48-49 $\mathrm{Ma}$ adapted from Billups and Schrag (2003).....

Figure 1.8. High-performance liquid chromatography base-peak chromatograms showing tetraether lipid composition of surface sediments

Figure 1.9. Paleogeographic reconstruction of New Zealand in Early Eocene time from Hollis et al. (2009). 30

Figure 1.10. Cretaceous and Cenozoic stratigraphy of north Canterbury from Forsyth et al. (2008).

Figure 1.11. The mid-Waipara river section showing the position of the six lithologic columns, 1 to 6 , and the sample suite that was collected during the 2003 GNS survey from Morgans et al. (2005). 33

Figure 1.12. Sample locations, biostratigraphy and age model of the Ashley Mudstone sequence from the mid-Waipara River section from Hollis et al. (2009).

\section{Chapter 2.}

Figure 2.1. Examples of LA-ICP-MS trace element depth profiles showing the different types of profiles through foraminifera test walls and how these are screened to yield reliable $\mathrm{Mg} / \mathrm{Ca}$ data. 
Figure 2.2. Unscreened $\mathrm{Mg} / \mathrm{Ca}-\mathrm{Al} / \mathrm{Ca}$ data for 5 main species, excluding analyses with extreme values for $\mathrm{Al} / \mathrm{Ca}(>50 \mathrm{mmol} / \mathrm{mol})$, which is used to approximately determine the contaminant composition.

\section{Chapter 3.}

Figure 1. Paleogeographic map of New Zealand during the Early Eocene at ca. 55 Ma (after Hollis et al., 2009).

Figure 2. Scanning electron microscope images illustrating the variable preservation of mid-Waipara planktonic and benthic foraminifer tests.

Figure 3. Examples of LA-ICP-MS trace element depth profiles showing the different types of profiles through foraminifera test walls and how these are screened to yield reliable $\mathrm{Mg} / \mathrm{Ca}$ data.

Figure 4. Paleo-sea temperature data from the mid-Waipara section. 70

Figure 5. Mid-Waipara proxy data showing the agreement between the different temperature records available for this locality in the Eocene.

Figure 6. Graphical illustration of the sensitivity of temperature reconstructions to seawater $\mathrm{Mg} / \mathrm{Ca}$ ratios.

Figure 7. $\mathrm{Mn} / \mathrm{Ca}$ data from mid-Waipara (red squares; this study). The range of $\mathrm{Mn} / \mathrm{Ca}$ ratios found in modern foraminifera analysed by LA-ICP-MS (black rectangle; Marr, 2009) is also shown, and these are superimposed on thallium isotope data (blue diamonds) from Nielsen et al. (2009)

\section{Chapter 4.}

Figure 4.1. $\mathrm{Zn} / \mathrm{Ca}(\mathrm{a})$ and $\mathrm{Ba} / \mathrm{Ca}(\mathrm{b})$ data from 5 species of foraminifera from midWaipara. Boxes with diagonal bars indicate 'typical' values from modern foraminifera of $\mathrm{Zn} / \mathrm{Ca}$ (Lea, 2003b) and $\mathrm{Ba} / \mathrm{Ca}$ (Rosenthal et al., 1999; Lea, 2003b; Marchitto et al., 2000, 2002).

Figure 4.2. The configuration of the Northern Hemisphere continents in the early Eocene, showing the geographic restriction of the Arctic basin (from Brinkhuis et al., 2006). Numbers and stars indicate site localities in the Arctic basin and Nordic seas where "Azolla pulses" have been identified. 


\section{LIST OF TABLES}

\section{Chapter 1.}

Table 1.1. Key benthic foraminifera used in paleobathymetric interpretation

\section{Chapter 2.}

Table 2.1. Silicate contamination screening limits on $\mathrm{Al} / \mathrm{Ca}$ for the 5 species used in the temperature-time record.

\section{Chapter 3.}

Table 1. Trace element data for up to 13 species from three mid-Waipara samples - MW106, MW112 and MW118 - used in a preliminary study to establish the most reliable species to analyse in this study

Table 2. Trace element/Ca ratios for the 5 selected species analysed throughout the mid-Waipara section showing variations in trace element chemistry over the period ca. $51-46.5 \mathrm{Ma}$.

Table 3. Reconstructed $\mathrm{Mg} / \mathrm{Ca}$ sea temperatures for the full suite of mid-Waipara samples, including model SST and BWT generated from $\mathrm{Mg} / \mathrm{Ca}$ data, and comparative $\delta^{18} \mathrm{O}$ and $\mathrm{TEX}_{86}$ temperatures from the same samples (Hollis et al., 2009).

\section{Chapter 4.}

Table 4.1. $\mathrm{Mg} / \mathrm{Ca}$ temperatures from Eocene planktonic and benthic foraminifera in the three samples MW106, MW112 and MW118, and mean offsets from the normalizing species $M$. crater (planktonic), and $C$. kurinuia (benthic)

\section{LIST OF PLATES}

\section{Chapter 1.}

Plate 1.1. SEM images of the 13 species of foraminifera studied from midWaipara . 


\section{Chapter 2.}

Plate 2.1. Specimens of V. marshalli prepared for LA-ICP-MS analysis, having been cleaned and mounted onto double sided tape attached to a wafer of NIST610 silicate glass standard.

\section{LIST OF APPENDICES}

Note: Appendices are included in electronic form on a CD, rear cover.

Appendix 1. Samples

Appendix 2. Trace Element Depth Profiles and SEM Images 


\section{INTRODUCTION}

\subsection{General Introduction}

The Earth's climate system is extremely complex, with multiple forcing and feedback mechanisms. While a wealth of modern observational climate data exists, with instrumental data spanning back to the mid-19th century, climate cannot be directly measured for the past. As such, scientists rely on a variety of proxies - things that have changed chemically or physically in response to changes in climate in a measurable and predictable way - to determine the past state of Earth's climate system. For example, these changes are frequently observed in terms of the fossil fauna, sedimentology and chemistry of marine sediments. Over the last half-century, a number of geochemical proxies have been added to the toolkit of paleoclimate research, providing quantitative information about past environmental conditions. Advances in technology and analytical instrumentation (e.g. mass spectrometry) have continued to occur, offering more tools, more applications, and ever improving precision. Applying these proxies to the geological record has produced quantitative ocean temperature estimates back through geological time, and support existing qualitative evidence for dramatic changes in global climate over the last 100 million years, often occurring on very rapid timescales. For example, a $7^{\circ} \mathrm{C}$ warming in just $50 \mathrm{yr}$ at ca. $10.7 \mathrm{kyr}$ ago has been inferred from stable oxygen isotope analysis of ice core records from Greenland (Dansgaard et al., 1989).

Intervals of extreme global warmth, known as greenhouse periods, have been inferred during the Cretaceous and the Early Cenozoic based on the geographical distributions of temperature-sensitive marine and terrestrial organisms, leaf and tree ring characteristics, sedimentary facies distributions, and the absence of high-latitude glacial deposits (Poulsen et al., 1999). A picture has emerged of the greenhouse world, with poles that were free of continental ice, without freezing winters (Greenwood and Wing, 1995), where crocodilians and turtles thrived in the high latitudes (Markwick, 1998), and palm trees grew as far north as Siberia (Greenwood and Wing, 1995). A range of temperature proxies from marine sediments and deep-sea cores provide quantitative temperature estimates that support this view (Shackleton and Kennett, 1975; Shackleton and Boersma, 1981; Miller et al., 1987, 2005a; Zachos et al., 1994, 2001, 2008; Hollis et al., 2009; Bijl et al., 2009). The greenhouse world of the early Cenozoic was followed 
by a long term cooling trend through to the Oligocene, and the build up of large, permanent ice sheets on Antarctica, and the so-called 'icehouse world'. The tipping point between these two contrasting states of the Earth came about in the Early Eocene, around 50 Myr ago (Zachos et al., 2001). The extreme warmth of the Early Eocene greenhouse, and the beginning of the greenhouse to icehouse transition are the focus of this study.

This study uses a proxy based on the thermodynamic incorporation of magnesium into foraminiferal calcite to reconstruct past ocean temperatures (Clarke and Wheeler, 1922; Nürnberg et al., 1996; Lea et al., 1999; Mashiotta et al., 1999). Foraminifera were sampled and analysed from sediments of the Canterbury Basin, New Zealand, to estimate sea temperatures for the mid-latitude southwest Pacific at the greenhouse to icehouse transition. New micro-analytical techniques were used, employing laser ablation ICP-MS for in situ trace element analysis of foraminifera, yielding depth profiles that allow for the identification and exclusion of contaminant phases. This method can overcome some of the problems that have previously limited confidence in $\mathrm{Mg} / \mathrm{Ca}$ based climate reconstructions, such as diagenetic overprinting, in older foraminifera.

\subsection{Thesis Structure and Outline}

This thesis aims to use foraminifera from mid-Waipara, north Canterbury, New Zealand, to reconstruct sea temperatures from the southern mid-latitudes from the early to middle Eocene using the $\mathrm{Mg} / \mathrm{Ca}$ paleothermometer. The work addresses the question of whether reliable sea temperature estimates can be extracted from these variably preserved Eocene foraminifera using in situ laser ablation techniques and the $\mathrm{Mg} / \mathrm{Ca}$ paleothermometer by comparing $\mathrm{Mg} / \mathrm{Ca}$ temperature data with two independent temperature proxies. The temperature reconstruction contributes to a multiproxy study from mid-Waipara, providing a detailed record of climate across this time period, which is used to make inferences about the degree of warmth, oceanographic conditions, and whether or not the climate was stable during this greenhouse period.

This thesis begins in Chapter 1 by introducing the paleoclimate setting of the Paleogene and, in particular, the greenhouse world of the Early Eocene. The paleoclimate proxies that are used to reconstruct the climate record, and details of the 
samples and their localities are then presented. Chapter 2 then describes the methods for trace element analysis and data reduction procedures that were used to produce the laser ablation ICP-MS Mg/Ca paleotemperature record. Chapter 3 presents the trace element data and the reconstructed multiproxy paleotemperature record for mid-Waipara in a format prepared for publication in the journal Earth and Planetary Science Letters (EPSL). Chapter 4 expands on some aspects of the mid-Waipara data that were omitted from Chapter 3 due to length requirements. Chapter 5 presents the conclusions of this study and suggestions for future work. A list of all of the samples used and related information, including comparative data from Hollis et al. (2009), is included in Appendix 1. Appendix 2 contains the complete set of trace element depth profiles used from analyses of foraminifera in this study, and includes scanning electron microscope (SEM) images of foraminifera in which the corresponding laser ablation pits can be seen.

\subsection{Climate in the Greenhouse World}

The global climate of the Early Paleogene (see Figure 1.1) was dominated by a warming trend, culminating with a period of stable warm climate called the Early Eocene Climatic Optimum, followed by a 17 Myr long cooling trend that represents the transition from greenhouse to icehouse conditions (Figure 1.2). There are lingering questions about whether the greenhouse climate was stable or unstable, and whether the transition was gradual or stepwise. A review of the literature regarding Paleogene climate is presented below, providing a context for this thesis. 


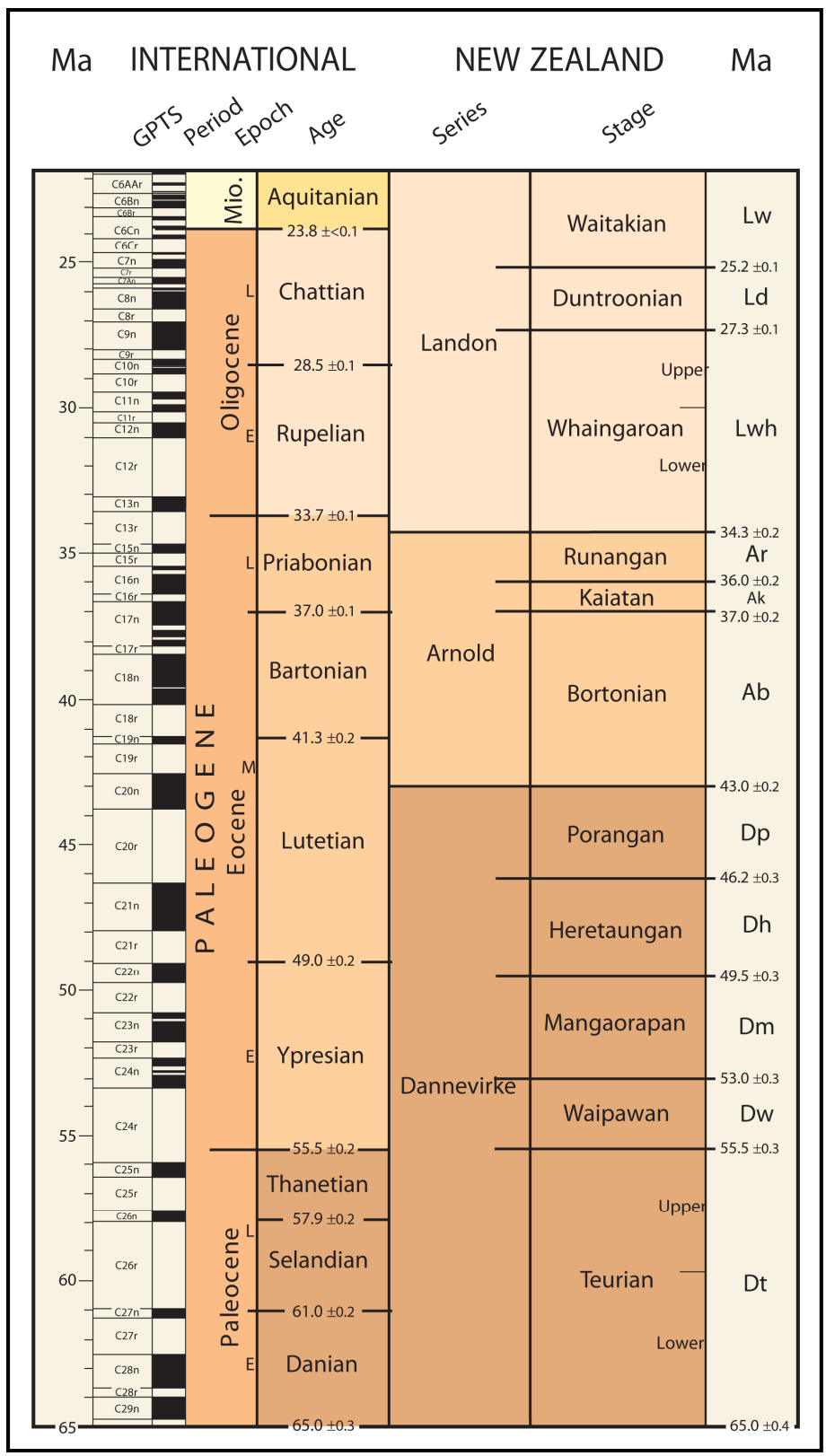

Figure 1.1. New Zealand geological timescale for the Paleogene (after Cooper, 2004).

\subsubsection{Paleogene Climate}

Pre 65 Ma - Cretaceous: super-greenhouse

In order to establish the context for the Early Eocene greenhouse world it is necessary to briefly review the even warmer Cretaceous period, the archetypal greenhouse setting. Extreme warmth in the Cretaceous has been inferred for a long time from qualitative evidence, such as geographical distributions of temperature-sensitive organisms, leaf and tree ring characteristics, sedimentary facies distributions, and the absence of high-latitude glacial deposits (Poulsen et al., 1999). Geochemical proxy data from marine sediments have provided quantitative evidence for this global warmth, with 
estimated peak sea surface temperatures in the middle Cretaceous of $32-33^{\circ} \mathrm{C}$ in the proto-North Atlantic (e.g. Kolodny and Raab, 1988; Wilson and Norris, 2001; Norris et al., 2002; Schouten et al., 2003; Bice et al., 2006), $27-32^{\circ} \mathrm{C}$ for the equatorial Pacific (Schouten et al., 2003), and up to $33^{\circ} \mathrm{C}$ in the southern high latitudes (Huber et al., 1995). Temperatures in the Arctic may have reached as high as $20^{\circ} \mathrm{C}$ (Jenkyns et al., 2004).

Over the remainder of the Cretaceous a cooling trend is observed, with temperatures falling to $10-12^{\circ} \mathrm{C}$ in the southern high-latitudes by the uppermost Maastrichtian (Pirrie and Marshall, 1990; Huber et al., 1995). This was followed by the bolide impact and mass extinction at the Cretaceous-Paleogene (K-T) boundary (Alvarez et al., 1980; Schulte et al., 2010).

65 - 55 Ma - Paleocene: cooler climate, transient warming events

The cooling trend of the Late Cretaceous continued into the Paleocene, reaching a minimum around 59 - $58 \mathrm{Ma}$ (Zachos et al., 2001; Tripati et al., 2003; Bijl et al., 2009). The cooling affected the high latitudes more than the low latitudes, with sea surface temperatures reaching $c a .20^{\circ} \mathrm{C}$ at the East Tasman Rise (Bijl et al., 2009), while maintaining temperatures of $c a .31^{\circ} \mathrm{C}$ in the tropical Pacific (Tripati et al., 2003). The size of fossil snake vertebrae has been used to infer mean annual temperatures of $30-34^{\circ} \mathrm{C}$ in Colombia (paleolatitude $5.5^{\circ} \mathrm{N}$, Head et al., 2009). The global deep-sea benthic $\delta^{18} \mathrm{O}$ record yields temperatures of $c a .8^{\circ} \mathrm{C}$, indicating that deep water was still relatively cool (Zachos et al., 2001, 2008; Figure 1.2). After ca. 58 Ma, temperatures began to rise again and the trend of warming continued through to the Early Eocene.

At the latest Paleocene ( $c a .55 \mathrm{Ma}$ ), the warming trend was punctuated by an abrupt and extreme transient warming event, known as the Paleocene-Eocene Thermal Maximum (PETM, Zachos et al., 2001; also known as the Late Paleocene Thermal Maximum (LPTM) or Eocene Thermal Maximum 1 (ETM1)). The PETM was accompanied by a large negative shift in carbon isotopes recorded in marine carbonates (Figure 1.2), indicating rapid injection of isotopically light carbon into the ocean and atmosphere, which has been attributed to the degassing of unstable methane clathrates from ocean bottom sediments (Dickens et al., 1995). The release of methane from clathrates was probably triggered by changes in ocean circulation (Bice and Marotzke, 
2002; Lourens et al., 2005; Tripati and Elderfield, 2005). This produced high atmospheric concentrations of methane and (as methane is oxidized) carbon dioxide, resulting in an extreme greenhouse effect and causing the climate to warm rapidly and radically. A suite of proxy evidence show that global sea surface temperatures increased by at least $4-8^{\circ} \mathrm{C}$ during the PETM (Röhl et al., 2000; Zachos et al., 2003, 2006; Tripati and Elderfield, 2004, 2005), with evidence for temperatures in the Arctic Ocean in excess of $23^{\circ} \mathrm{C}$ (Sluijs et al., 2006). The release of these gases was geologically instant, taking place in $<20 \mathrm{kyr}$ (Röhl et al,. 2000), and the entire warming interval lasted ca. 170 kyr before returning to background temperatures and the warming trend that preceded it (Röhl et al., 2007). The negative carbon isotope excursion at the PETM now defines the Paleocene-Eocene boundary (Figure 1.1, Figure 1.2).

\section{5 - 33 Ma - Eocene: greenhouse, followed by cooling to icehouse}

Following the PETM, the warming trend of the Late Paleocene continued. Several additional transient warming events, superimposed on this trend, have been identified during the Early Eocene. While much smaller, they are similar in nature to the PETM in that they were also accompanied by negative excursions in $\delta^{13} \mathrm{C}$, suggesting they involved a similar trigger to the PETM. These smaller 'hyperthermal' events were first recognized in the tropical Atlantic (ETM2/ELMO - Lourens et al., 2005; ETM3/"X" Röhl et al., 2005), and have since been observed elsewhere, including New Zealand (Nicolo et al., 2007).

The warming of the Early Eocene peaked with an extended period of stable warm climate called the Early Eocene Climatic Optimum (EECO) that is defined by a broad minimum in global $\delta^{18} \mathrm{O}$ that ranges from ca. 53 - $50 \mathrm{Ma}$ (Zachos et al., 2001; Figure 1.2). The EECO is broadly equivalent to the New Zealand Mangaorapan stage (53 - 49.5 Ma; Cooper, 2004). This $\delta^{18} \mathrm{O}$ minimum represents a $1.5 \%$ decrease in benthic $\delta^{18} \mathrm{O}$ since the mid-Paleocene - equivalent to an increase in deep ocean bottom water temperatures of $c a .6^{\circ} \mathrm{C}$ (Zachos et al., 1994, 2001). Deep-sea (>1000 m) benthic $\delta^{18} \mathrm{O}$ records yield bottom water temperatures of $10-13^{\circ} \mathrm{C}$ (Shackleton and Boersma, 1981; Zachos et al., 2001). Sea surface temperature proxies yield peak temperatures of $29-34^{\circ} \mathrm{C}$ in the equatorial Pacific (Tripati et al., 2003), Atlantic (Andreasson and Schmitz, 1998) and Indian (Pearson et al., 2001, 2007) Oceans. Temperatures in excess 
of $30^{\circ} \mathrm{C}$ have been recorded in the southwest Pacific (Hollis et al., 2009; Bijl et al., 2009).

Following the termination of the EECO, a 17 Myr long trend towards cooler conditions emerged. This trend was not entirely constant, being interrupted at around 41 Ma by a transient warming event of $c a .2-4^{\circ} \mathrm{C}$ named the Middle Eocene Climatic Optimum (MECO; Bohaty and Zachos, 2003). This transient event is different to those of the Early Eocene as it occurs during a period of general cooling, and is not accompanied by a shift in $\delta^{13} \mathrm{C}$, which suggests that it involved a different mechanism as compared to the older transient warming events (Bohaty and Zachos, 2003). The cooling trend of the Mid- and Late-Eocene continued until the Eocene-Oligocene boundary at $c a .33 \mathrm{Ma}$.

\section{Ma - Oligocene: icehouse}

Over the interval $50-33 \mathrm{Ma}$, a net global cooling of $c a \cdot 10^{\circ} \mathrm{C}$ in sea surface temperatures is observed (Miller et al., 1987; Lear et al., 2000; Zachos et al., 2001; Pearson et al., 2007; Bijl et al., 2009). By the Eocene-Oligocene boundary, sea-surface temperatures at the East Tasman rise had decreased to ca. $19-21^{\circ} \mathrm{C}$ (Bijl et al., 2009).

Small ephemeral ice sheets may have been present on Antarctica since the middle Eocene (Ehrmann and Mackensen, 1992). Oxygen isotope records show a large positive shift occurring at ca. 33 Ma (Oi-1 event) signifying a large scale cooling and the establishment of large permanent ice sheets on Antarctica (Zachos et al., 1996). The Oi-1 event represents the final step in the global climatic shift from the greenhouse world of the Early Eocene to the icehouse world of the Oligocene. 


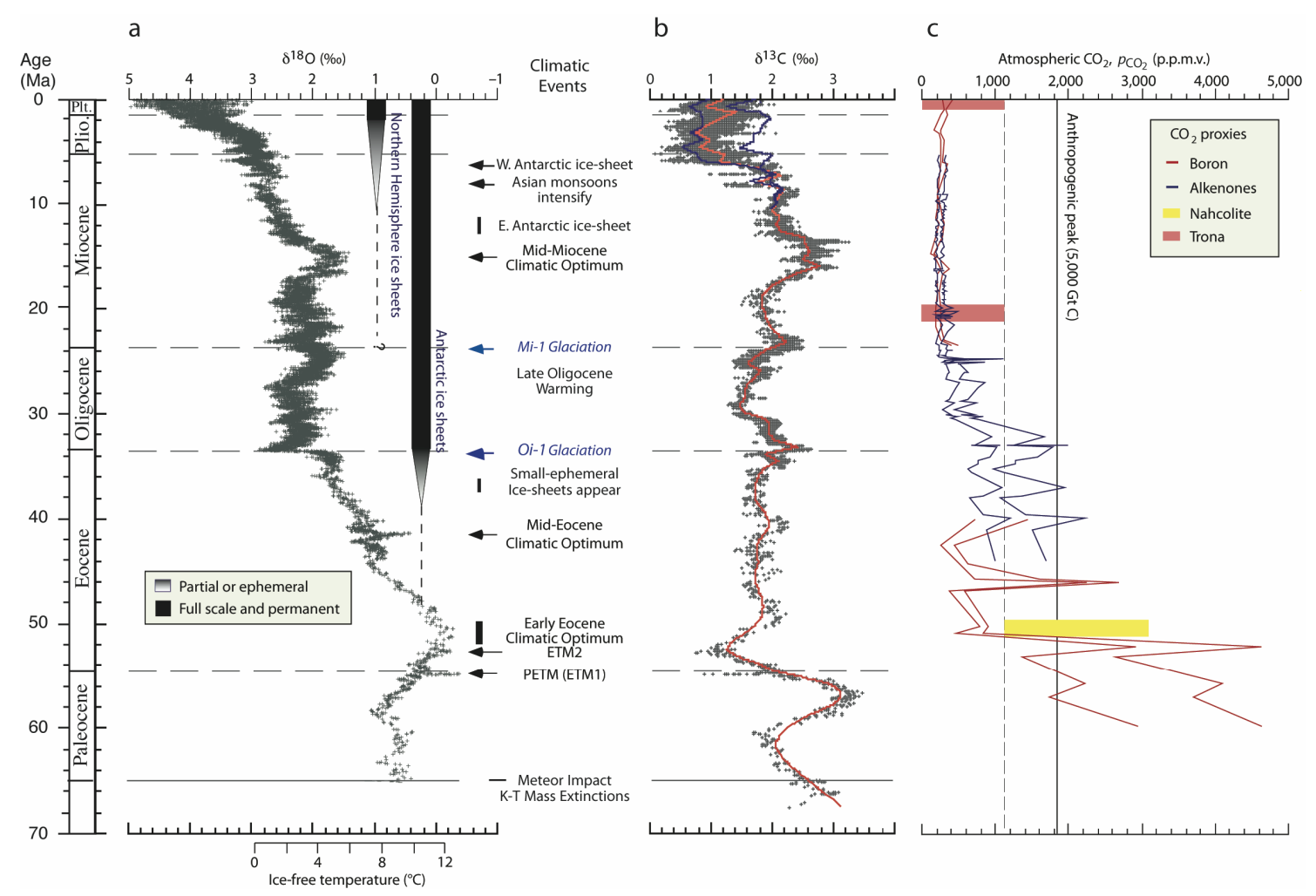

Figure 1.2. Cenozoic climate $\left(\delta^{18} \mathrm{O}\right)$, carbon isotope $\left(\delta^{13} \mathrm{C}\right)$ and $p \mathrm{CO}_{2}$ data for the period 0 to 65 million years, adapted from Zachos et al. (2001) and Zachos et al. (2008). (a) The climate curve is a global composite stack of deep-sea benthic $\delta^{18} O$ (Zachos et al., 2001). The $\delta^{18} \mathrm{O}$ temperature scale, on the bottom axis, was computed on the assumption of an ice-free ocean; it therefore applies only to the time preceding the onset of large-scale glaciation on Antarctica (about 35 Myr ago). The figure shows the 2-million-year-long EECO and the more transient MECO, and the very short-lived early Eocene hyperthermals such as the PETM and ETM2. (b) Global deep-sea carbon isotope record based on data compiled from more than 40 ODP and DSDP sites. The large excursions associated with transient hyperthermal events in the Late Paleocene/Early Eocene can be clearly seen in the $\delta^{13} \mathrm{C}$ record. (c) Atmospheric $\mathrm{CO}_{2}$ data are a compilation of proxy records (Royer, 2006; Lowenstein and Demicco, 2006). The dashed vertical line represents the maximum $p \mathrm{CO}_{2}$ for the Neogene (Miocene to present) and the minimum $p \mathrm{CO}_{2}$ for the early Eocene (1,125 ppm).

\subsubsection{Atmospheric $\mathrm{CO}_{2}$ record}

The link between atmospheric carbon dioxide and global surface temperatures has been recognized for over a century (Arrhenius, 1896; Chamberlin, 1899). It is generally accepted that there is a causal link between the increase in atmospheric $\mathrm{CO}_{2}$ since the industrial revolution and the concomitant increase in global surface temperatures. Trapped gases in ice cores - the only direct measurement of atmospheric composition over geological time - show a strong correlation between greenhouse gas $\left(\mathrm{CO}_{2}, \mathrm{CH}_{4}\right.$, $\mathrm{N}_{2} \mathrm{O}$ ) concentrations and temperature for at least the last 650,000 years (Petit et al., 1999; Siegenthaler et al., 2005; Spahni et al., 2005). 
Beyond the temporal range of ice cores, a variety of proxies have been developed to reconstruct $\mathrm{pCO}_{2}$ from the geological record. These include plant stomatal indices (Van Der Burgh et al., 1993; Royer et al., 2001; Retallack, 2001), carbon isotopes in terrestrial plant fossils (Fletcher et al., 2008) and marine sediments (Pagani et al., 2005), carbonates in fossil soils (Cerling, 1991; Breecker et al., 2010), boron isotopic composition $\left(\delta^{11} \mathrm{~B}\right)$ of foraminiferal calcite (Hemming and Hanson, 1992; Pearson and Palmer, 1999, 2000; Pearson et al., 2009), and the mineralogy of primary ocean and lacustrine carbonates (Demicco et al., 2003; Lowenstein and Demicco, 2006). These studies have produced a range of estimates of $\mathrm{pCO}_{2}$ for the Early Eocene ranging from ca. 300 to 3500 ppmv, but they generally indicate high concentrations of $\mathrm{CO}_{2}$ in the Late Cretaceous and earliest Cenozoic, gradually declining through to the Oligocene.

Estimates of $\mathrm{pCO}_{2}$ from the Paleogene show a strong coupling with the climate trends outline in Section 1.3.1 (Figure 1.2). The Early Eocene has become a focus of paleoclimate research because it was the most recent time in Earth's history when atmospheric greenhouse gas concentrations were drastically higher than they are today.

\subsubsection{Cenozoic Ice Volume}

The Early Eocene greenhouse world is generally considered to have been free of continental ice (Lear et al., 2000; Zachos et al., 2001). Recent studies have combined the use of the $\mathrm{Mg} / \mathrm{Ca}$ paleothermometer and $\delta^{18} \mathrm{O}$ to decouple the effects of temperature and ice volume from $\delta^{18} \mathrm{O}$ records, producing a record of global ice volume during the Cenozoic (Figure 1.3) (Lear et al., 2000; Billups and Schrag, 2003). These studies indicate that changes in $\delta^{18} \mathrm{O}$ observed in the Early Eocene result primarily from changes in temperature, and that there was no significant continental ice, although some studies have suggested that Antarctica was intermittently glaciated during the Early Cenozoic (Miller et al., 1991, 2005a). The presence of ice rafted material in Arctic (Moran et al., 2006) and Antarctic (Ehrmann and Mackensen, 1992) sediments suggests small ephemeral ice sheets may have developed in middle Eocene time (ca. 45.5 Ma,). However, permanent large-scale ice sheets did not develop until around the EoceneOligocene boundary (ca. $33 \mathrm{Ma}$; Zachos et al., 1996). The opening of ocean gateways at the South Tasman Rise and Drake Passage bringing about the thermal isolation of Antarctica has long been recognized as a possible cause of the abrupt change at the 
Eocene-Oligocene boundary (Kennett, 1977; Diester-Haass and Zahn, 1996; Barker, 2001; Lawver and Gahagan, 1998, 2003; Livermore et al., 2005). Climate modelling studies (Crowley and North, 1991; Barrera and Huber, 1993; Crowley, 1998; DeConto and Pollard, 2003; Huber et al., 2004; Lear et al., 2008), modelling of biogeochemical and carbon cycle processes (Zachos and Kump, 2005; Merico et al., 2008) and variations in carbonate compensation depth (Coxall et al., 2005) suggest that ice sheet formation was triggered when declining atmospheric $\mathrm{CO}_{2}$ levels dropped below a critical threshold. This $\mathrm{pCO}_{2}$ threshold has been estimated at $750 \mathrm{ppm}$ (DeConto and Pollard, 2003; DeConto et al., 2008), and estimates of $\mathrm{pCO}_{2}$ from the boron isotope proxy suggest that this threshold was in fact crossed during the Eocene-Oligocene climate transition (Pearson et al., 2009), suggesting declining $\mathrm{CO}_{2}$ had a central role in the development of the Antarctic ice sheets.
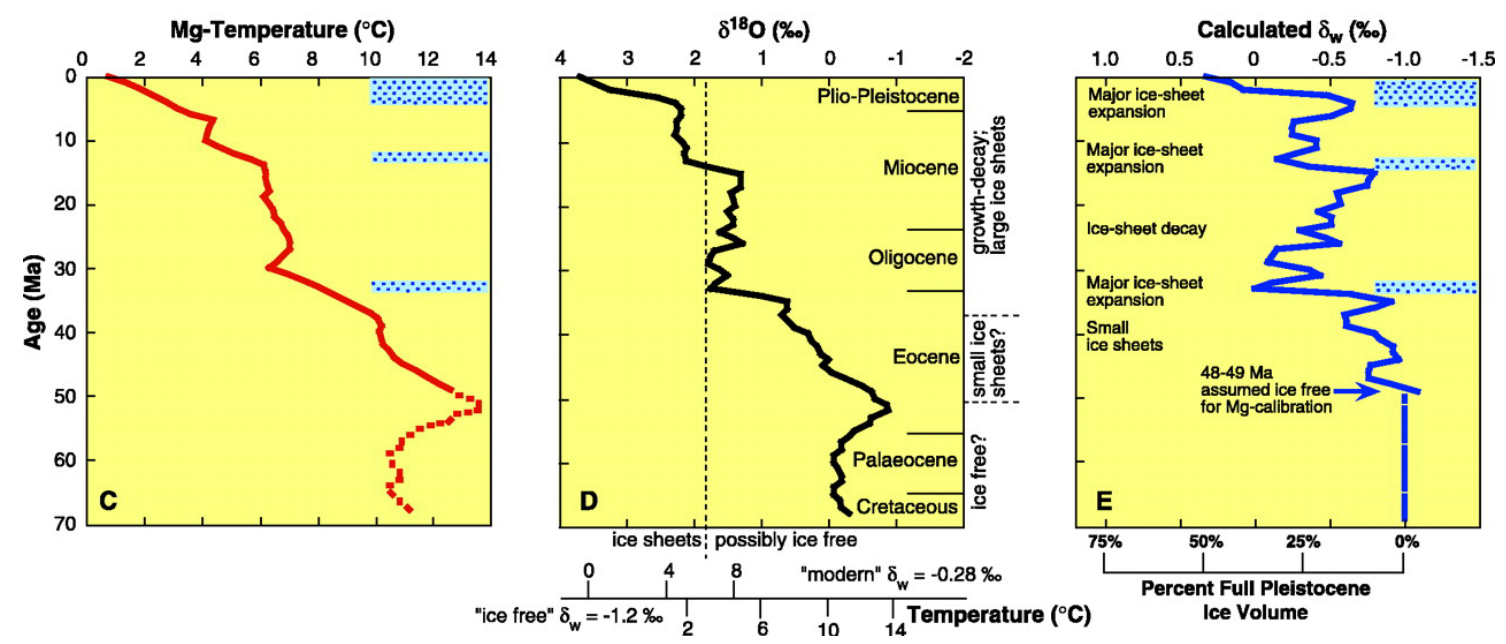

Figure 1.3. Cenozoic ice volume reconstruction from Lear et al. (2000). By removing the effect of temperature on the $\delta^{18} \mathrm{O}$ signal, the oxygen isotope composition of seawater can be reconstructed. Benthic seawater $\delta^{18} \mathrm{O}$ is dominantly controlled by global ice volume, and thus the combination of the $\mathrm{Mg} / \mathrm{Ca}$ and $\delta^{18} \mathrm{O}$ proxies can be used to reconstruct ice volume through the Cenozoic.

\subsubsection{Outstanding Problems}

Multiproxy studies have reported hypertropical SSTs in excess of $30^{\circ} \mathrm{C}$ during the Eocene in the coastal North Atlantic (Zachos et al., 2006) and western central Indian oceans (Pearson et al., 2007). Similarly, SSTs in excess $30^{\circ} \mathrm{C}$ have been derived for the low-latitude Pacific from $\mathrm{Mg} / \mathrm{Ca}$ ratios (Tripati et al., 2003; Sexton et al., 2006), and for the East Tasman rise from $\mathrm{TEX}_{86}$ (Bijl et al., 2009). These high temperatures are consistent with estimates of high $\mathrm{pCO}_{2}$ for the Early Eocene (Pearson and Palmer, 
2000). $\mathrm{Mg} / \mathrm{Ca}$ based SST (Tripati et al., 2003) and BWT (Lear et al., 2000) records from low-latitude sites extend back over most of the Cenozoic, as do a number of global composite $\delta^{18} \mathrm{O}$ records (Miller et al., 1987, 1991, 2005a; Zachos et al., 2001, 2008; Cramer et al., 2009). Previous $\mathrm{Mg} / \mathrm{Ca}$ and $\delta^{18} \mathrm{O}$ based work has been based largely on measurements of bulk carbonates, with sampling at relatively low temporal resolution. Higher resolution records are required in order to resolve questions about abrupt changes in climate and to determine whether the climate in the greenhouse world was stable or unstable (Bohaty and Zachos, 2003). Additionally, as the Pacific may have been responsible for $\sim 90 \%$ of global ocean heat transport during the Paleogene (Huber and Sloan, 2001), robust constraints on ocean temperatures in the Eocene Pacific Ocean are essential for our understanding of early Cenozoic climate drivers. However, to date multiproxy data sets or robust high latitude data for the Pacific have been lacking (Hollis et al., 2009).

In order to address these questions, it is necessary to develop methods to extract more information from the sedimentary record. The approach of this thesis is to develop methods to extract reliable sea temperature information from less than ideally preserved foraminifera specimens, which would mean that many more samples could be utilized in the reconstruction of paleotemperatures.

\subsection{Paleoclimate Proxies}

This section introduces the geochemical proxies that are used to produce quantitative paleoclimate records back through geological time. These paleothermometers are complementary and can be used in parallel in multi-proxy studies to provide confidence in climate reconstructions. Oxygen isotopes are the most established of these proxies, whereas $\mathrm{Mg} / \mathrm{Ca}$ and $\mathrm{TEX}_{86}$ are still relatively novel, having largely been developed over the last one or two decades. This section provides a background to each proxy. As the $\mathrm{Mg} / \mathrm{Ca}$ paleothermometer is the basis of this thesis, it is covered first and in the greatest detail. 


\subsubsection{Mg/Ca Paleothermometer}

\section{Background}

The first suggestion that $\mathrm{Mg}$ in calcite may have potential as a thermometer came in 1922, with the observation that marine carbonates precipitated in warm waters had more $\mathrm{Mg}$ than those precipitated in cooler waters (Clarke and Wheeler, 1922). In the 1970s it was discovered that dissolution on the seafloor or in sediments could significantly alter the $\mathrm{Mg} / \mathrm{Ca}$ ratio of foraminifera tests (Bender et al., 1975; Hecht et al., 1975; Lorens et al., 1977), following which little hope was held for the usefulness of the proxy. In the 1990s, studies of planktonic foraminifera from oceanic depth transects showed that foraminiferal $\mathrm{Mg} / \mathrm{Ca}$ decreased with water depth (Rosenthal and Boyle, 1993; Russell et al., 1994; Brown and Elderfield, 1996), and that dissolution had a greater effect on high-Mg calcite (Brown and Elderfield, 1996). The interest of the paleoclimate community returned to the $\mathrm{Mg} / \mathrm{Ca}$ proxy after convincing $\mathrm{Mg} / \mathrm{Ca}-$ temperature relationships in cultured, core-top and down core planktonic foraminifera were published (Nürnberg, 1995; Nürnberg et al., 1996), and the thermodynamic relationship between $\mathrm{Mg} / \mathrm{Ca}$ and temperature began to be understood (Nürnberg et al., 1996; Rosenthal et al., 1997). These developments combined with advances in analytical instruments and methods have seen the $\mathrm{Mg} / \mathrm{Ca}$ proxy become amongst the fastest developing areas of paleoclimate research over the last decade. During that time, a number of $\mathrm{Mg} / \mathrm{Ca}$-temperature calibrations have been developed for different species, secondary effects have been identified and quantified, and temperature reconstructions have been produced throughout the Cenozoic (e.g. Lear et al., 2000; Billups and Schrag, 2003).

\section{Temperature control on $\mathrm{Mg}$ incorporation in calcite}

The substitution of $\mathrm{Mg}$ for $\mathrm{Ca}$ in foraminiferal calcite is endothermic, and is thus favoured at higher temperatures. Thermodynamic equations predict an exponential increase in $\mathrm{Mg} / \mathrm{Ca}$ of $3 \%$ per ${ }^{\circ} \mathrm{C}$ (Lea et al., 1999). Inorganic precipitation experiments generally follow this thermodynamic prediction (e.g. Oomori et al., 1987), however, foraminiferal calcite contains 5-10 times less magnesium than predicted from thermodynamic calculations (Bender et al., 1975), and shows a $\sim 3$ times greater $\mathrm{Mg}$ sensitivity to temperature of $9 \pm 1 \%$ per ${ }^{\circ} \mathrm{C}$ (Lea et al., 1999). As temperature 
uncertainties depend on the relative magnitude of the temperature response versus sources of error, the increased temperature sensitivity of the $\mathrm{Mg} / \mathrm{Ca}$ thermometer in foraminiferal calcite presents a significant advantage (Lea, 2003a).

The ratio of magnesium to calcium in the calcite tests of many species of foraminifera has been shown to vary exponentially as a function of calcification temperature (Figure 1.4a) (Nürnberg et al., 1996; Lea et al., 1999; Mashiotta et al., 1999; Elderfield and Ganssen, 2000; Lear et al., 2000). The $\mathrm{Mg} / \mathrm{Ca}$ ratio is related to calcification temperature by the equation:

$$
\mathrm{Mg} / \mathrm{Ca}(\mathrm{mmol} / \mathrm{mol})=\left(\frac{\mathrm{Mg} / \mathrm{Ca}_{\mathrm{sw}-\mathrm{t}}}{\mathrm{Mg} / \mathrm{Ca}_{\mathrm{sw}-0}}\right) A \exp ^{B T}
$$

equation 1.1

where $\mathrm{Mg} / \mathrm{Ca} a_{\text {sw }}$ is seawater $\mathrm{Mg} / \mathrm{Ca}$ at time $\mathrm{t}$ and at the present day (subscript $\mathrm{t}$ and 0 , respectively) (omitted for modern samples), $A$ is the pre-exponential constant, $B$ is the exponential constant, and $T$ is temperature (Lear et al., 2002). The constants $A$ and $B$ relate to the characteristics of a particular species incorporation of $\mathrm{Mg}$ into its calcite shell. On a log-linear scale, this exponential function becomes a straight line, where the intercept is the pre-exponential constant, $A$, and the slope is the exponential constant, $B$ (Figure 1.4b). Thus, the exponential constant, $B$, determines the magnitude of temperature change from down core variations in $\mathrm{Mg} / \mathrm{Ca}$, and the pre-exponential constant, $A$, determines the absolute temperature (Lea, 2003a). The value of $B$ in the $\mathrm{Mg} / \mathrm{Ca}$-temperature calibration can be read as the $\mathrm{Mg} / \mathrm{Ca}$-temperature sensitivity of that species: for example, the generalised planktonic calibration $\mathrm{Mg} / \mathrm{Ca}=0.38 \exp (0.09 \times \mathrm{T})$ (Anand et al., 2003) indicates a $\mathrm{Mg} / \mathrm{Ca}$ increase of $9 \%$ per ${ }^{\circ} \mathrm{C}$ increase in sea surface temperature.

Lear et al. (2000) identified a set of four parameters that must be addressed in order to produce a temperature record from foraminiferal $\mathrm{Mg} / \mathrm{Ca}$ data:

1- $\mathrm{A} \mathrm{Mg} / \mathrm{Ca}$-temperature calibration is required for the species being studied.

2- $\mathrm{The} \mathrm{Mg} / \mathrm{Ca}$ of seawater at the time of interest must be estimated.

3- The preservation of primary $\mathrm{Mg} / \mathrm{Ca}$ values needs to be verified.

4- Any interspecific differences in $\mathrm{Mg} / \mathrm{Ca}$-temperature calibrations must be understood.

These factors are addressed sequentially in the following sections. 


\section{Mg/Ca-temperature calibrations}

The incorporation of $\mathrm{Mg}$ into foraminiferal calcite varies between species, with large differences between planktonic and benthic taxa, and thus a unique calibration is required for each species being considered. For modern species, these values are calibrated by fitting a function to empirical data from core-top (foraminifera separated from soft sediments from the top of deep sea cores), sediment trap (foraminifera from sediments collected over time by a trap on the sea floor), plankton tow (live foraminifera sampled from the surface of the ocean) and culturing studies (foraminifera grown in controlled conditions in a laboratory) (e.g. Mashiotta et al., 1999; Dekens et al., 2002; Lear et al., 2002; Anand et al., 2003). Measured $\mathrm{Mg} / \mathrm{Ca}$ ratios are plotted against measured temperatures or $\delta^{18} \mathrm{O}$ derived calcification temperatures, revealing an exponential relationship between these factors (Figure 1.4a). An exponential curve is fitted to the data, and the best-fitting curve is taken as the calibration for that species. Many calibrations now exist for individual species and multi-species calibrations have also been developed for planktonic foraminifera that accurately represent the $\mathrm{Mg} / \mathrm{Ca}-$ temperature relationship for a variety of species (e.g. Anand et al., 2003). In the case of the Eocene foraminifera used in this study, there are no extant specimens upon which such calibrations can be performed and, as such, calibrations from similar modern species are utilized (Lear et al., 2000, 2002; Tripati et al., 2003). 

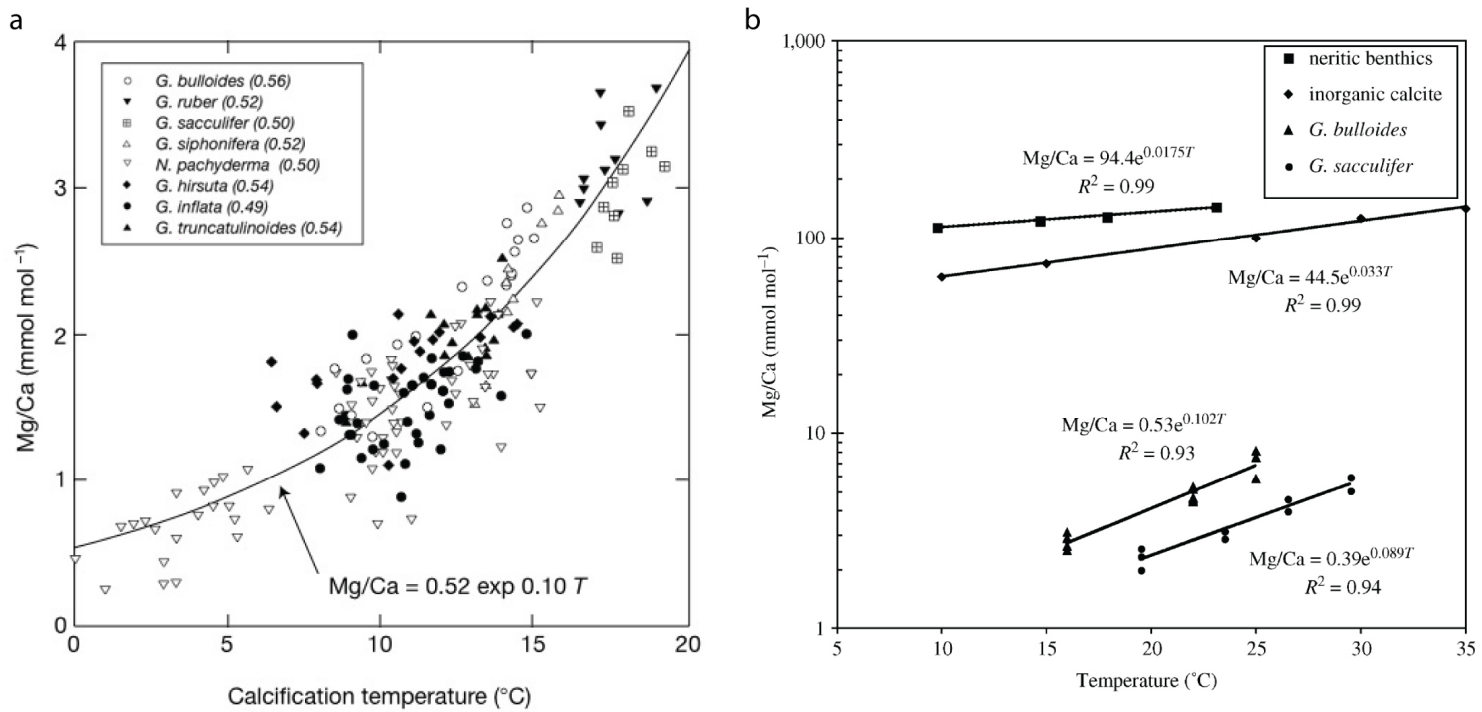

Figure 1.4. $\mathrm{Mg} / \mathrm{Ca}$-temperature calibration curves. (a) $\mathrm{Mg} / \mathrm{Ca}$ versus calcification temperature for eight planktonic species of foraminifera from a core-top sample (from Elderfield and Ganssen, 2000). A calibration curve has been fitted, showing the exponential relationship between $\mathrm{Mg} / \mathrm{Ca}$ and calcification temperature. (b) Comparison of $\mathrm{Mg} / \mathrm{Ca}$ - temperature relationships from Lea (2003) for inorganic calcite precipitation (Oomori et al., 1987), neritic benthic foraminifera (Toyofuku et al., 2000), a tropical spinose symbiont bearing planktonic foraminifera, G. sacculifer (Nürnberg et al., 1996), and a subpolar spinose symbiont barren planktonic foraminifera, G. bulloides (Lea et al., 1999). This demonstrates the large difference in temperature sensitivity between planktonic and benthic taxa. Note that on a log-linear scale, the exponential relationship is decomposed to a straight line, the slope and intercept of which give the constants $A$ and $B$ respectively.

\section{Interspecies differences}

Systematic differences in $\mathrm{Mg} / \mathrm{Ca}$ are observed between species of foraminifera (when using a common calibration), as has been previously observed in $\delta^{18} \mathrm{O}$ studies (Shackleton and Kennett, 1975). These differences arise from vital effects that differ between species, and result in artificial temperature offsets between foraminifera that shared the same habitat. To correct for these differences, $\mathrm{Mg} / \mathrm{Ca}$ ratios or temperatures from different taxa are normalized or cross-calibrated to a chosen species from a similar habitat (e.g. Lear et al., 2000).

\section{$\mathrm{Mg} /$ Ca ratio of seawater}

$\mathrm{Mg}$ and $\mathrm{Ca}$ have relatively long residence times in the ocean (10 and $1 \mathrm{Myr}$, respectively) and thus the $\mathrm{Mg} / \mathrm{Ca}$ ratio of seawater may be considered to be constant over short (e.g. glacial/interglacial) timescales (Lear et al., 2002; Barker et al., 2005). However, the $\mathrm{Mg} / \mathrm{Ca}$ of seawater has changed over timescales of tens of millions of 
years, and in order to derive temperatures from $\mathrm{Mg} / \mathrm{Ca}$ ratios of Eocene foraminifera, temporal changes in the $\mathrm{Mg} / \mathrm{Ca}$ of seawater $\left(\mathrm{Mg} / \mathrm{Ca}_{\mathrm{sw}}\right)$ must be taken into account.

Secular changes in the major ion chemistry $\left(\mathrm{Na}^{+}, \mathrm{K}^{+}, \mathrm{Ca}^{2+}, \mathrm{Mg}^{2+}, \mathrm{Cl}^{-}, \mathrm{SO}_{4}{ }^{2-}\right.$, $\mathrm{HCO}_{3}{ }^{-}$) of seawater are driven by geochemical processes, particularly changes in the rate of production and hydrothermal alteration of the oceanic crust, the rate of continental weathering, and deposition of marine carbonates. The reservoirs and paths of surface $\mathrm{Mg}$ and $\mathrm{Ca}$ transfer are shown in Figure 1.5. Weathering of continental rocks is the source of $\mathrm{Mg}$ to the ocean, which is removed both by deposition of dolomite, and by hydrothermal alteration at mid-ocean ridges. Continental weathering also delivers $\mathrm{Ca}$ to the ocean, which is removed by precipitation of marine limestones.

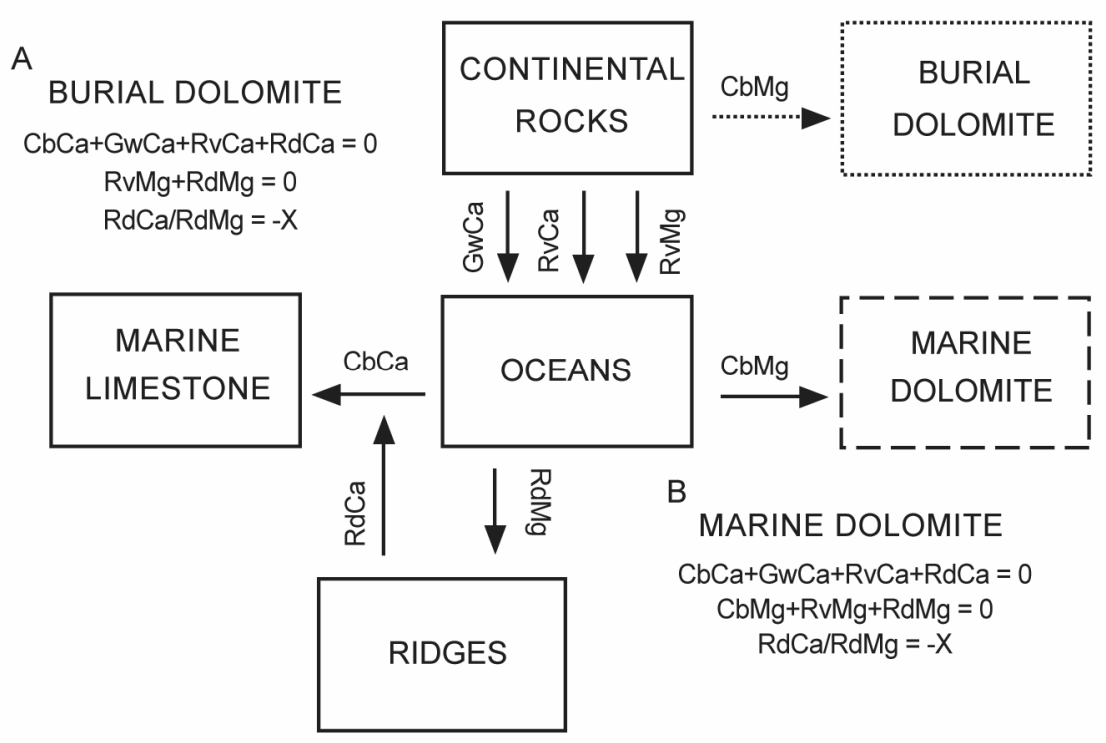

Figure 1.5. Primary reservoirs and paths of $\mathrm{Ca}$ and $\mathrm{Mg}$ transfer at the Earth's surface (from Wilkinson and Algeo, 1989). RvCa and RvMg are river fluxes; $\mathrm{CbCa}$ and $\mathrm{CbCa}$ are fluxes to carbonate reservoirs; $\mathrm{RdCa}$ and $\mathrm{RdMg}$ are fluxes through oceanic ridges; GwCa is a groundwater seepage and/or carbonate dissolution flux.

Various proxies and models have been used to estimate $\mathrm{Mg} / \mathrm{Ca} \mathrm{sw}_{\mathrm{sw}}$ through time (Figure 1.6). Early indications that the major ion chemistry of the ocean had changed significantly over time came from studies of the primary mineralogy of nonskeletal limestone, which showed that the ocean has oscillated between two modes of carbonate deposition twice over the Phanerozoic (last $540 \mathrm{Myr}$ ): 1- deposition of low Mg calcite; 2- deposition of aragonite + high Mg calcite (Sandberg, 1983). Over the same interval, salts in marine evaporite deposits fluctuated between $\mathrm{KCl}$ and $\mathrm{MgSO}_{4}$, in step with the 
calcite-aragonite oscillations (Hardie, 1996), and in phase with oscillations in seafloor spreading rates, volcanism and global sea level (Lowenstein et al., 2001). Further constraints on the chemistry of paleo-seawater have been provided by other proxy evidence, such as fluid inclusions in marine halites (Zimmermann, 2000; Lowenstein et al., 2001; Horita et al., 2002), fossil echinoderms formed in equilibrium with seawater (Dickson, 2002), strontium concentrations in biological calcites (Steuber and Veizer, 2002), and $\mathrm{CaCl}_{2}$ basinal brines (Lowenstein et al., 2003). Lear et al. (2002) took a different approach, whereby $\mathrm{Mg} / \mathrm{Ca}$ temperatures were calculated from Eocene benthic foraminifera using a range of values for $\mathrm{Mg} / \mathrm{Ca}$ sw , and the resulting temperatures were compared with $\delta^{18} \mathrm{O}$ temperatures (assumed to be entirely temperature dependent in an ice-free Eocene world). The value of $\mathrm{Mg} / \mathrm{Ca}_{\mathrm{sw}}$ that yielded the closest agreement between $\mathrm{Mg} / \mathrm{Ca}$ and $\delta^{18} \mathrm{O}$ derived temperatures was taken to be the $\mathrm{Mg} / \mathrm{Ca}$ ratio of seawater.

Several computer models, which predict the $\mathrm{Mg} / \mathrm{Ca}$ of seawater from approximated balances between the geochemical fluxes in Figure 1.5, have also been used to model seawater chemistry over the Phanerozoic (Figure 1.6) (Wilkinson and Algeo, 1989; Hardie, 1996; Stanley and Hardie, 1998). 


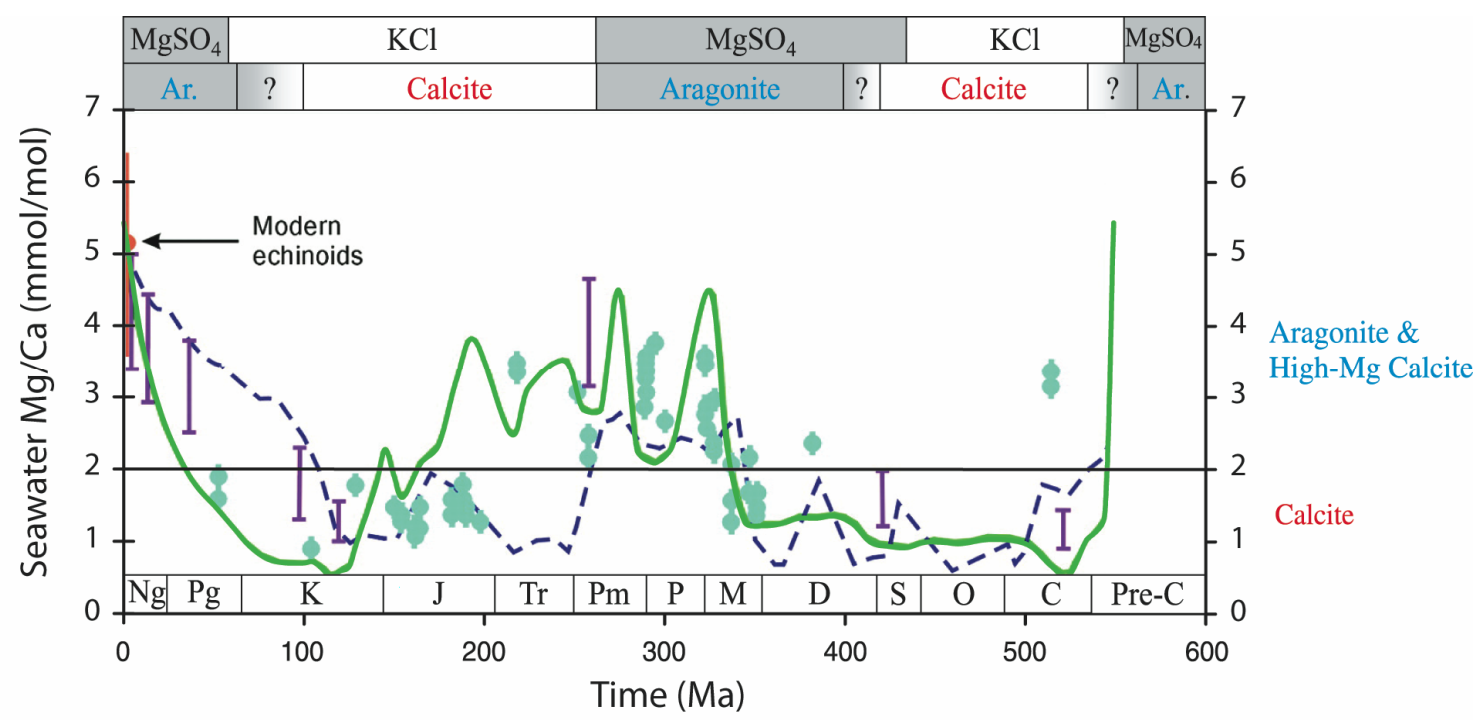

Figure 1.6. $\mathrm{Mg} / \mathrm{Ca}$ of seawater over time from various proxy and model data, adapted from Lowenstein et al. (2001) and Dickson et al. (2001). Green dots are from fossil echinoderms, with vertical lines representing possible temperature error. The dashed blue line is a model from Wilkinson and Algeo (1989); the solid green line is a model from Hardie (1996). The vertical purple lines are from fluid inclusion estimates (Lowenstein et al., 2001). Also plotted (top bar) are the temporal distributions in the primary mineralogies of Phanerozoic non-skeletal carbonates (Sandberg, 1983) and KCl and $\mathrm{MgSO}_{4}$ evaporites (Hardie, 1996). Geological periods are indicated in the bottom bar.

The general agreement between seawater $\mathrm{Mg} / \mathrm{Ca}$ from models and proxy data is reasonably good, however, the $\mathrm{Mg} / \mathrm{Ca}$ of seawater for the Early Eocene is still relatively poorly constrained. Proxies and models produce a range of estimates of the $\mathrm{Mg} / \mathrm{Ca}$ of Eocene seawater, ranging from ca. $1.5-3.5 \mathrm{mmol} / \mathrm{mol}$. The sensitivity of $\mathrm{Mg} / \mathrm{Ca}$ temperature reconstructions to the seawater $\mathrm{Mg} / \mathrm{Ca}$ ratio is shown in Figure 1.7. Thus, this range of estimates of Eocene seawater $\mathrm{Mg} / \mathrm{Ca}$ imposes temperature uncertainties of ca. $\pm 4^{\circ} \mathrm{C}$ during the Eocene. However, for reasonable choices of seawater $\mathrm{Mg} / \mathrm{Ca}$, there is good temperature agreement between $\delta^{18} \mathrm{O}$ and $\mathrm{Mg} / \mathrm{Ca}$ in well-preserved foraminifera (Sexton et al., 2006).

It is important to note that the $\mathrm{Mg} / \mathrm{Ca}$ of seawater and the pre-exponential constant of the $\mathrm{Mg} / \mathrm{Ca}$ temperature equation are not required to calculate the magnitude of relatively short-term changes in temperature using the $\mathrm{Mg} / \mathrm{Ca}$ paleothermometer (Lear et al, 2002). Thus, even if absolute temperatures are inaccurate, the variations observed in the Eocene record are still reliable. 


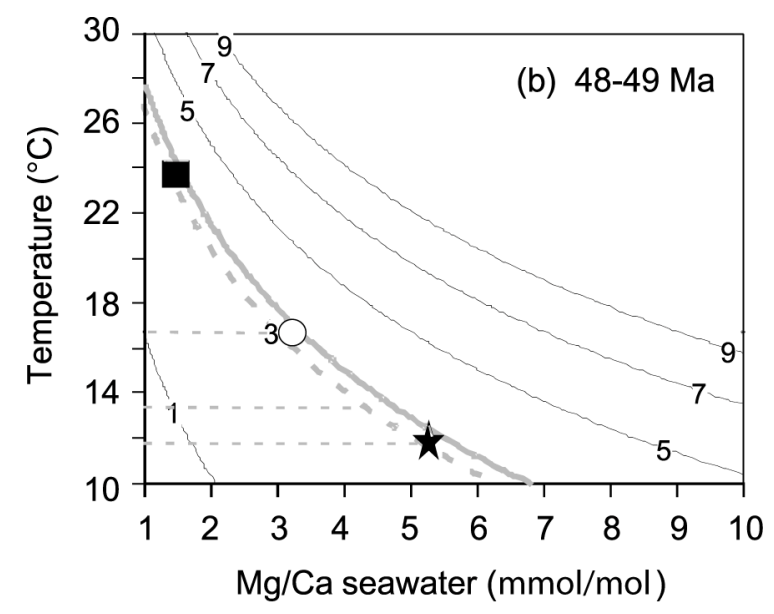

Figure 1.7. Graphical illustration of the sensitivity of temperature reconstructions ( $y$-axis) to seawater $\mathrm{Mg} / \mathrm{Ca}$ ratios (x-axis) at 48-49 Ma adapted from Billups and Schrag (2003).

The contours (benthic foraminiferal $\mathrm{Mg} / \mathrm{Ca}$ ratios in $\mathrm{mmol} / \mathrm{mol}$ ) were derived using the temperature calibration of Lear et al. (2002). The solid square denotes the intersection between observed foraminiferal $\mathrm{Mg} / \mathrm{Ca}$ ratios and seawater $\mathrm{Mg} / \mathrm{Ca}$ ratios of Stanley and Hardie (1998), the open circle marks the intersection between observed foraminiferal $\mathrm{Mg} / \mathrm{Ca}$ ratios and seawater $\mathrm{Mg} / \mathrm{Ca}$ ratios of Wilkinson and Algeo (1989), and the star indicates the intersection between observed foraminiferal $\mathrm{Mg} / \mathrm{Ca}$ ratios and modern seawater Mg/Ca ratios (Elderfield and Schultz, 1996).

\section{Preservation of primary foraminiferal Mg/Ca signal}

There are a number of post-depositional processes that can alter primary $\mathrm{Mg} / \mathrm{Ca}$ ratios of foraminiferal calcite. It has been known since the 1970s that dissolution on the seafloor or in sediments could significantly alter the $\mathrm{Mg} / \mathrm{Ca}$ ratio of foraminifera tests (Bender et al., 1975; Hecht et al., 1975; Lorens et al., 1977). In modern foraminifera, $\mathrm{Mg} / \mathrm{Ca}$ decreases as a function of deposition depth, as demonstrated by measuring $\mathrm{Mg} / \mathrm{Ca}$ ratios of planktonic foraminifera from oceanic depth transects (Brown and Elderfield, 1996). Seafloor dissolution has been shown to selectively remove the more soluble high $\mathrm{Mg} / \mathrm{Ca}$ (and low $\delta^{18} \mathrm{O}$ ) portions of foraminifera tests (Rosenthal et al., 2000; Rosenthal and Lohmann, 2002), although seafloor dissolution is likely to be less significant at continental shelf depths than at the depths considered by these studies (1600 - 4400 m; Brown and Elderfield, 1996).

Diagenetic processes can also alter the $\mathrm{Mg} / \mathrm{Ca}$ ratio of foraminifera tests, and these processes may or may not be easily recognizable. For example, the precipitation of overgrowths of inorganic calcite on the inner and outer surfaces of the shells can usually be identified under the optical microscope. However, diagenetic recrystallization affects 
foraminifera on a micrometre scale, and a shell may become thoroughly recrystallized without obliterating structures such as wall pores, internal shell layering features and surface ornament, making it difficult to recognize (Pearson et al., 2001). These types of alteration are enhanced by increased rates of pore-water flow and increased burial pressure (Schrag, 1999), and thus the best preservation is expected from relatively impermeable sediments that have not been buried deeply or exposed to high temperatures.

Efforts to overcome these issues include monitoring of trace elements that are sensitive to these processes, careful selection of foraminiferal samples, and combining records from multiple proxies. Excellently preserved specimens have been recovered from such sediments that appear 'glassy' under a light microscope like modern samples, as opposed to the 'frosty' appearance of typical foraminifera used in most previous studies (Pearson et al., 2001). However, such well-preserved specimens are rare, particularly in Paleogene sediments, and thus another analytical approach is taken to avoiding these problems in this thesis (section 2.2).

\section{Other secondary controls on the trace element composition of foraminifera}

There are additional factors besides temperature, dissolution and diagenesis that influence the chemistry of foraminifera. The most important of these is differences in the uptake of trace elements between species, requiring species-specific calibrations (which are not always available). Other environmental and ocean parameters, such as salinity (Nürnberg et al., 1996; Lea et al., 1999; Sadekov et al., 2009), carbonate ion speciation (Elderfield, 2002), pH (Elderfield, 2002; Lea, 2003a) and pressure (Elderfield et al., 1996) have been shown to have effects on biomineralisation and trace element incorporation in foraminifera. These effects, while generally presumed to be small, are difficult to quantify, and can complicate the interpretation of trace element data.

Additionally, many species of foraminifera migrate vertically in the water column and/or add gametogenic calcite at depths significantly deeper than their primary habitat depth, resulting in natural heterogeneity in shell chemistry where different chambers of an individual have different $\mathrm{Mg} / \mathrm{Ca}$ ratios that may not reflect real changes in ocean temperature (Bé, 1980; Eggins et al., 2003; Marr, 2009). Variability in Mg/Ca resulting 
from both primary and secondary controls is compounded by the fact that, as sediments accumulate slowly, sediment samples may contain a mixture of individuals from hundreds or thousands of years that will have lived at different times of the year or may been moved by currents, which is a natural source of scatter in trace element data.

\section{Additional trace element data}

Calcium in the calcite skeletons of marine organisms can be substituted by a variety of cations. This study focuses on the incorporation of $\mathrm{Mg}$ into foraminiferal calcite. However, the metals $\mathrm{Sr}, \mathrm{Mn}, \mathrm{Zn}$ and $\mathrm{Ba}$ (as well as $\mathrm{Fe}, \mathrm{Nd}$ and $\mathrm{Cd}$ ) are also known to form solid solutions isomorphous with calcite (Speer, 1983), and the ratios $\mathrm{Mn} / \mathrm{Ca}, \mathrm{Zn} / \mathrm{Ca}, \mathrm{Sr} / \mathrm{Ca}$ and $\mathrm{Ba} / \mathrm{Ca}$ were also measured as part of this study. As these elements are characterized by unique geochemical cycles, each element can provide different insights into changes in the ocean, and a brief summary of the behaviour of each element is given here. In order to derive any paleoceanographic information from the chemistry of foraminifera, one must first be assured the measured concentrations of these elements reflect that of primary foraminiferal calcite, and are not overprinted by extraneous contaminant phases or diagenetic effects. The rationale employed in this study for extracting reliable $\mathrm{Mg} / \mathrm{Ca}$ data from screened trace element depth profiles also applies to the other trace elements discussed here.

The manganese content of foraminifera is generally thought to reflect secondary diagenetic processes occurring on the seafloor, and the precipitation of $\mathrm{Mn}$ carbonate and oxyhydroxide phases at the sediment-water interface (Boyle, 1983; Pingitore et al., 1988; Lea et al., 1999) or in the sediment column (Wei et al., 2009). These phases are important in redox reactions in suboxic environments (Pingitore et al., 1988), and $\mathrm{Mn} / \mathrm{Ca}$ ratios are significantly higher in reducing sediments, where remobilised $\mathrm{Mn}$ and Fe are precipitated as oxides or oxyhydroxides (Boyle, 1983). The deposition of authigenic Fe-Mn oxyhydroxide phases in the ocean is largely controlled by redox conditions, which in turn depend on the amount of organic carbon deposition. The incorporation of Mn-rich carbonate and oxyhydroxide phases can have implications for $\mathrm{Mg} / \mathrm{Ca}$ paleo-ocean temperature reconstructions, as Mn-rich phases may also have relatively high $\mathrm{Mg}$ concentrations, and thus researchers often attempt to remove these 
phases by the inclusion of a reductive cleaning step in the sample preparation (Boyle, 1983; Pena et al., 2005; Weldeab et al., 2006).

Zinc is a micronutrient in the ocean and is preferentially concentrated in the deep ocean due to its efficient removal from surface waters and export to the deep ocean by biological organisms (Chan, 1977). In the deep ocean, $\mathrm{Zn}$ is remobilised by dissolution, and $\mathrm{Zn} / \mathrm{Ca}$ ratios of benthic foraminifera reflect bottom water dissolved $\mathrm{Zn}$ concentrations and the bottom water saturation state with respect to calcite (Marchitto et al., 2000). Bottom water dissolved $\mathrm{Zn}$ concentrations are in turn controlled by deep circulation and the global Zn inventory (Boyle, 1981; Marchitto et al., 2000). Thus, $\mathrm{Zn} / \mathrm{Ca}$ ratios have potential as recorders of the past distribution and circulation of deep water masses (Marchitto et al., 2000, 2002), and carbonate ion concentrations (Marchitto et al., 2002; Elderfield et al., 2006).

Strontium/calcium ratios have been used as a paleothermometer in corals (e.g. Gagan et al., 2000) However, studies of $\mathrm{Sr} / \mathrm{Ca}$ ratios of foraminifera have not conclusively shown any relationship between $\mathrm{Sr} / \mathrm{Ca}$ and temperature, and have indicated other potential controls on $\mathrm{Sr} / \mathrm{Ca}$ such as pressure (Rosenthal et al., 1997), salinity and $\mathrm{pH}$ (Lea et al., 1999). $\mathrm{Sr} / \mathrm{Ca}$ in foraminifera tests has been shown to be much more uniform than $\mathrm{Mg} / \mathrm{Ca}$ (Bender et al., 1975; Delaney et al., 1985). Records of foraminifera $\mathrm{Sr} / \mathrm{Ca}$ over the past $80 \mathrm{Myr}$ from planktonic (Graham et al., 1982; Delaney and Boyle, 1986) and benthic foraminifera (Lear et al., 2003) suggest that the Sr concentration of seawater has changed significantly. Foraminiferal $\mathrm{Sr} / \mathrm{Ca}$ has varied between 1.2 to 2.0 $\mathrm{mmol} / \mathrm{mol}$, with a minimum in $\mathrm{Sr} / \mathrm{Ca}$ observed during the Eocene ( $\mathrm{Sr} / \mathrm{Ca} \sim 1.2 \mathrm{mmol} / \mathrm{mol}$ ) (Graham et al., 1982; Lear et al., 2003). As $\mathrm{Sr} / \mathrm{Ca}$ is typically very constant within each test and uniform between samples (e.g. Eggins et al., 2003), $\mathrm{Sr} / \mathrm{Ca}$ ratios are useful indicators of disturbance of trace element ratios by severe alteration diagenesis.

Barium behaves similarly to refractory nutrients in the ocean. It is removed from the surface ocean by the uptake of $\mathrm{Ba}$ in the production of carbonates and the precipitation of barite (Bishop, 1988), and incorporated into sinking particles. These sinking particles later dissolve and release $\mathrm{Ba}$ in the deep ocean, which is reflected by deep-water maxima throughout the ocean (Lea and Boyle, 1991). Free Ba in the deep ocean can then be incorporated into sediments (Lea and Boyle, 1989). The $\mathrm{Ba} / \mathrm{Ca}$ ratio of foraminifera can be used to reconstruct the Ba composition of ocean bottom (benthic) 
and surface (planktonic) waters (Lea and Boyle, 1989, 1991, respectively). Various studies have demonstrated some potential for the use of $\mathrm{Ba} / \mathrm{Ca}$ ratios of foraminifera as a proxy for the biological productivity and nutrient content of the ocean (Lea and Boyle, 1989, 1991; Hall and Chan, 2004), changes in abyssal ocean circulation (Lea, 1993, 1995; Martin and Lea, 1998; Hall and Chan, 2004), and as an indicator of alkalinity (Lea, 1993, 1995). There is significant potential for contamination of $\mathrm{Ba} / \mathrm{Ca}$ ratios from the presence of barite, and studies of $\mathrm{Ba} / \mathrm{Ca}$ ratios of foraminifera usually include considerable cleaning steps (Lea and Boyle, 1991, 1993).

$\mathrm{Al} / \mathrm{Ca}$ ratios were also measured as part of this study. Although aluminium does not substitute into calcite like the metals mentioned above, $\mathrm{Al}$ is taken to represent the presence of detrital clay-like sediments (which have high concentrations of $\mathrm{Al}$ ), and $\mathrm{Al} / \mathrm{Ca}$ ratios were routinely used to monitor contamination from adhering or infilling sediments, as described in detail in Section 2.3.2.

\subsubsection{Oxygen Isotopes}

Oxygen isotopes are the most established and well understood of the various climate proxy records and provided the first quantitative records of global climate change during the Cenozoic (Shackleton and Kennett, 1975; Miller et al., 1987).

Oxygen isotope compositions are usually expressed in delta notation in per mil (\%o) units, relative to a standard (usually PeeDee Belemnite (PDB) for carbonates), where

$$
\delta^{18} \mathrm{O}=\frac{\left(\frac{{ }^{18} \mathrm{O}}{{ }^{16} \mathrm{O}}\right)_{\text {sample }}-\left(\frac{{ }^{18} \mathrm{O}}{{ }^{16} \mathrm{O}}\right)_{\text {standard }}}{\left(\frac{{ }^{18} \mathrm{O}}{{ }^{16} \mathrm{O}}\right)_{\text {standard }}} \times 1000
$$

equation 1.2

\section{Background}

The use of oxygen isotopes as a paleoclimate tool was first proposed by Harold Urey (1947). Urey and his students developed both the analytical instruments and methods to make the required isotope ratio measurements, and quantified the fractionation of oxygen isotopes between carbonates and seawater as a function of temperature enabling its use as a paleothermometer (Epstein et al., 1951). The original paleotemperature equation of Epstein et al. (1951) was based on molluscs, and showed sensitivity of $\sim-0.2 \%$ o change in $\delta^{18} \mathrm{O}$ per ${ }^{\circ} \mathrm{C}$. Emiliani (1955) applied the technique to 
planktonic foraminifera in deep sea cores, establishing their use as a paleothermometer, and found regular cyclical variations in $\delta^{18} \mathrm{O}$ interpreted to be cold intervals in the past. Emiliani's temperature record used the temperature calibration of Epstein et al. (1951), however Erez and Luz (1983) revised the equation of Epstein et al. to refer to planktonic foraminifera. Since then the proxy has been further refined with calibrations being produced for individual species, although the equation of Erez and Luz is still commonly used:

$$
T=17.0-4.52\left(\delta^{18} \mathrm{O}_{\mathrm{c}}-\delta^{18} \mathrm{O}_{\mathrm{w}}\right)+0.03\left(\delta^{18} \mathrm{O}_{\mathrm{c}}-\delta^{18} \mathrm{O}_{\mathrm{w}}\right)^{2} \quad \text { equation } 1.3
$$

where the subscripts $\mathrm{c}$ and sw refer to the carbonate and seawater, respectively. As equation 1.3 shows, the oxygen isotope composition of marine carbonates is controlled not only by the water temperature, but also the isotopic composition of the seawater $\left(\delta^{18} \mathrm{O}_{\mathrm{sw}}\right)$ from which the carbonate crystallised.

The two major controls on the oxygen isotope composition of seawater are global ice volume and salinity, although other factors such as $\mathrm{pH}$ and alkalinity may have a small effect (Spero et al., 1997). Salinity varies regionally with changes in the balance between evaporation and precipitation, and the mixing history of the local water masses. With some knowledge of the paleoceanography of a particular site, paleosalinity can be estimated.

Continental ice is a storage reservoir for ${ }^{16} \mathrm{O}$, which is preferentially (not exclusively) taken up during evaporation, leaving the ocean enriched in the heavier isotope of oxygen $\left({ }^{18} \mathrm{O}\right)$. Changes in the volume of global continental ice have a significant effect on the $\delta^{18} \mathrm{O}$ value of the ocean. These factors lead to some ambiguity in $\delta^{18} \mathrm{O}$-based paleo-ocean temperature reconstructions, except for periods during which the world is thought to have been free of continental ice, such as during the Cretaceous and the Early Eocene. Values taken for the $\delta^{18} \mathrm{O}_{\mathrm{sw}}$ for the ice-free world are usually either -1 \%o (Zachos et al., 1994) or -1.2\%o (Shackleton and Boersma, 1981).

As noted by Lear et al. (2000), the coupled effects of temperature and ice volume complexity in carbonate $\delta^{18} \mathrm{O}$ can actually be advantageous. If an independent record of ocean temperature is available, then equation 1.3 can be rearranged to calculate $\delta^{18} \mathrm{O}_{\mathrm{sw}}$, decoupling the temperature and ice volume effects. The deep ocean is insulated from large seasonal, latitudinal, and geographical variations in temperature and salinity, thus 
the $\delta^{18} \mathrm{O}$ of seawater in the deep oceans primarily records global continental ice volume. Therefore, when combined with an independent temperature proxy like $\mathrm{Mg} / \mathrm{Ca}$ ratios, benthic $\delta^{18} \mathrm{O}$ data can be used to reconstruct ice volume in the past. Reconstructions done in this manner extend back to the Early Eocene (Figure 1.3; Lear et al., 2000; Billups and Schrag, 2003).

Early studies of foraminifera separated from deep-sea cores extending back to the Early Eocene found reconstructed $\delta^{18} \mathrm{O}$ sea surface temperatures from tropical sites were surprisingly cool (e.g. Shackleton and Boersma, 1981), while at the same time yielding warm sea surface temperatures from the high latitudes, and warm bottom water temperatures from benthic foraminifera (Pearson et al., 2001). This came to be known as the cool tropics paradox (D'Hondt and Arthur, 1996), and required researchers to invoke difficult to prove modes of heat transport to explain the relatively low equator to pole temperature gradients (Crowley and Zachos, 2000; Huber and Sloan, 2001). However, Pearson et al. (2001) found that exceptionally well preserved, 'glassy' foraminifera from Tanzania yielded $\delta^{18} \mathrm{O}$ temperature estimates that are warmer by 5$10^{\circ} \mathrm{C}$ than those previously documented for equatorial regions. This led Pearson et al. to postulate that previous studies had been biased to lower temperatures by fine-scale diagenetic recrystallization of planktonic foraminifer shells, which occurs at shallow burial depths. This has been supported by $\mathrm{Mg} / \mathrm{Ca}$ ratios of foraminifera from the same sites (Tripati et al., 2003) and oxygen isotopes in molluscs (Kobashi et al., 2001), which give evidence for high SSTs at low latitudes in the Eocene.

\section{Mid-Waipara $\delta^{18} \mathrm{O}$ data}

Oxygen isotope data have been measured and published (Hollis et al., 2009) from the same mid-Waipara samples used for the $\mathrm{Mg} / \mathrm{Ca}$ study presented here. Planktonic foraminifera of the genus Morozovella were used as an indicator of SST, and the benthic genus Cibicides was used as an indicator of BWT, which is thought to represent intermediate water in this upper bathyal setting (Hollis et al., 2009). Temperature estimates from $\delta^{18} \mathrm{O}$ were based on analyses of single specimens of foraminifera, and were calculated using the equation of Erez and Luz (1983), assuming an ice-free $\delta^{18} \mathrm{O}_{\text {sw }}$ value of $-1 \%$ (Zachos et al., 1994). No corrections were made for surface-water salinity or other isotopic fractionation effects. 


\subsubsection{TEX $X_{86}$}

\section{Background}

$\mathrm{TEX}_{86}$ (TetraEther indeX of tetraethers consisting of 86 carbon atoms) is a recently developed organic geochemistry proxy for sea surface temperature based on the marine picoplankton Crenarchaeota (Schouten et al., 2002, 2007). These ubiquitous microorganisms make up $20-30 \%$ of the picoplankton in present-day oceans (Schouten et al., 2000; Sinninghe Damsté et al., 2002). Whilst alive, these organisms adjust the chemistry of lipids in their cell walls ( $0-4$ cyclopentane rings and, in one case, a cyclohexane ring; Figure 1.8) in response to changes in temperature in order to regulate their membrane fluidity. When the organisms die these lipid cells are incorporated into sediments. The lipids can be separated from sediments using solvents, and the proportions of the different types of lipids can be measured using liquid chromatography chemical ionisation mass spectrometry. A study of sediments from around the globe showed that the distribution of these tetraether lipids varies with SST (Schouten et al., 2002). This distribution is thought to be independent of surface water parameters such as salinity or nutrient availability (Wuchter et al., 2004).

The $\mathrm{TEX}_{86}$ index is computed by the equation:

$$
\mathrm{TEX}_{86}=\frac{([\mathrm{IV}]+[\mathrm{V}]+[\mathrm{VI}])}{([\mathrm{III}]+[\mathrm{IV}]+[\mathrm{V}]+[\mathrm{VI}])}
$$

from Schouten et al., (2002), where the roman numerals refer to the different types of glycerol dialkyl glycerol tetraethers (GDGTs) shown in Figure 1.8. 

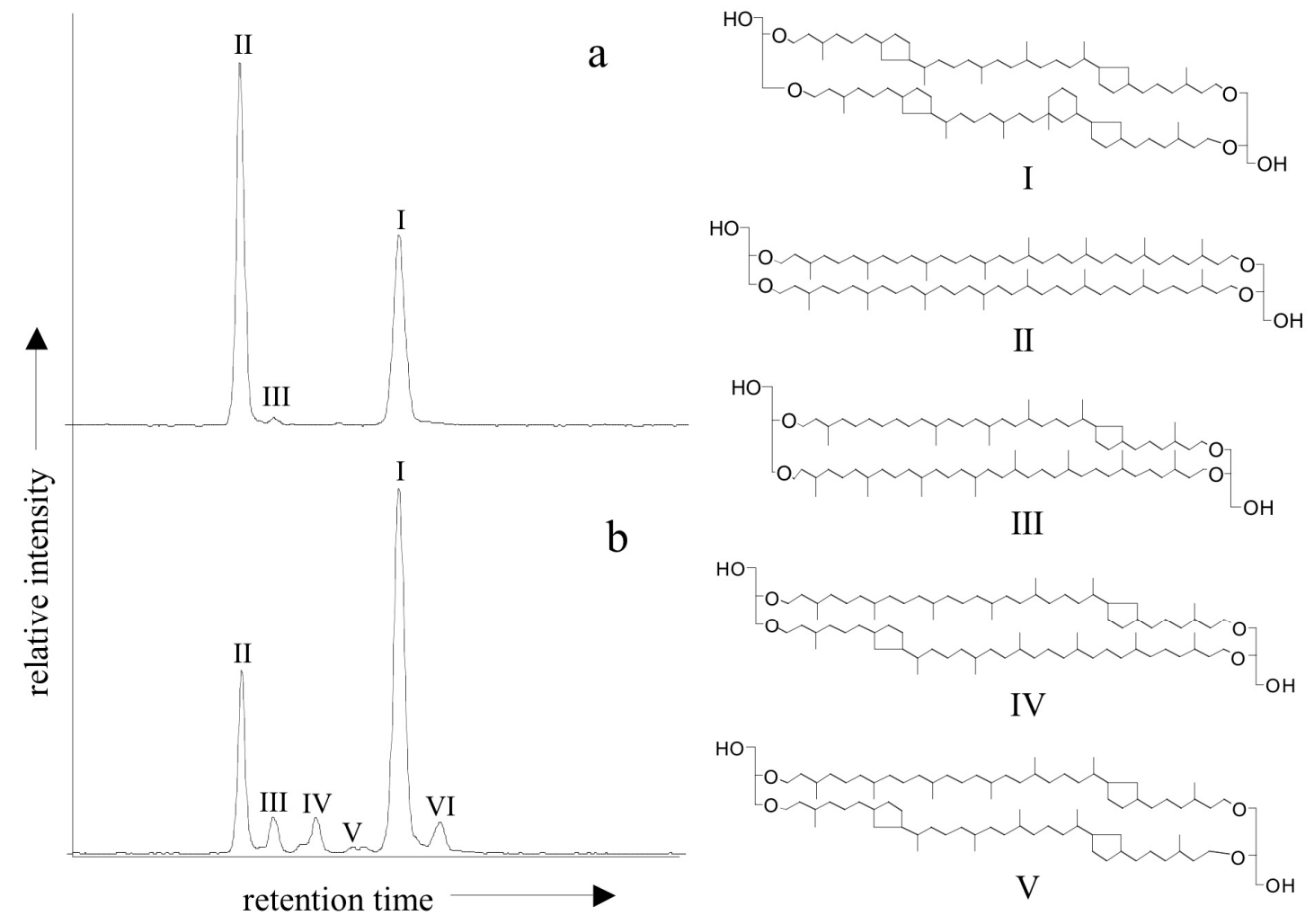

Figure 1.8. High-performance liquid chromatography base-peak chromatograms showing tetraether lipid composition of surface sediments from (A) Halley Bay station (Antarctica) and $(B)$ the Arabian Sea. The difference in relative proportions of various tetraether lipid structures (indicated by roman numerals) can be seen in the chromatograms. The relative proportions are quantified by integrating peak areas in the respective traces of tetraether lipids, and the $\mathrm{TEX}_{86}$ index is calculated from equation 1.4. The $\mathrm{TEX}_{86}$ index can then be converted to temperature using a calibration such as in equation 1.5.

In order to convert $\mathrm{TEX}_{86}$ to temperature, a calibration is produced using empirical data from sites in the modern ocean with known temperatures, which can then be applied to samples from the geological record. Over recent years, calibrations for $\mathrm{TEX}_{86}$ continue to be refined. Kim et al. (2008) published a widely used calibration based on global core-top data, which assumes a linear relationship between water temperature and $\mathrm{TEX}_{86}$ values:

$$
S S T=-10.78+56.24 \times \mathrm{TEX}_{86}
$$

equation 1.5

However, this calibration is not yet universally accepted. Liu et al. (2009) argued that the exclusion by Kim et al. (2008) of some core-top locations and outliers from the linear calibration narrows its geological application, and they produced a non-linear calibration from the same core-top sample set that fits all of the available data: 


$$
S S T=50.47+16.33 \times\left(1 / \mathrm{TEX}_{86}\right) \quad \text { equation } 1.6
$$

Where $\left(1 / \mathrm{TEX}_{86}\right)$ is the reciprocal of equation 1.4:

$$
\frac{1}{\mathrm{TEX}_{86}}=\frac{[\mathrm{III}]}{[\mathrm{IV}]+[\mathrm{V}]+[\mathrm{VI}]}+1
$$

equation 1.7

Bijl et al. (2009) have since responded, arguing that the exclusion of some data is appropriate due to the different behaviour of Crenarchaeota in some special settings, and have continued to use the Kim et al. (2008) calibration. Thus, the issue is not yet resolved, and these two recent and contrasting calibrations result in a discordance in the $\mathrm{TEX}_{86}$ estimates of tropical sea surface temperatures. The Kim et al. calibration yields higher temperatures than the Liu et al. calibration, and the disparity between the two increases with temperature.

\section{Mid-Waipara $\mathrm{TEX}_{86}$ data}

In addition to $\mathrm{Mg} / \mathrm{Ca}$ and $\delta^{18} \mathrm{O}$ data, Hollis et al. (2009) also published a suite of $\mathrm{TEX}_{86}$ data from the mid-Waipara samples. Conversion of TEX 86 values into SST were completed using methods outlined by Schouten et al. (2002, 2003, 2007), and using the revised calibration of $\mathrm{Kim}$ et al. (2008). Here the same data are converted to temperature using both the linear calibration of Kim et al. (2008) and the non-linear calibration of Liu et al. (2009).

\subsubsection{Other Proxy Information}

In addition to the climate proxies above, Hollis et al. (2009) published two other geochemical proxy records from mid-Waipara, providing information on other aspects of the Eocene ocean at that locality. As information from these additional proxies is relevant to some of the climate interpretations made later in this thesis, they are briefly introduced here. The data from these proxies is included in Appendix 1.

Stable isotopes of carbon

Carbon isotopes are also commonly measured in tandem with oxygen isotopes in marine carbonates. Carbon has two stable isotopes, ${ }^{13} \mathrm{C}$ and ${ }^{12} \mathrm{C}$, and exists in a range of 
oxidation states, making it a fundamental element of the biosphere and hydrosphere (Sharp, 2007). Stable isotope ratios of carbon are also expressed in delta notation, relative to a standard (usually $\mathrm{PDB}$, as for $\delta^{18} \mathrm{O}$ ), in per mil (\%o) units. The fractionation of these isotopes between the oceans, the atmosphere and the biosphere is controlled by the global carbon cycle and various biogeochemical processes. The heavier isotope $\left({ }^{13} \mathrm{C}\right)$ is concentrated in the more oxidized forms (e.g. $\mathrm{CO}_{2}$, carbonates), and the lighter isotope $\left({ }^{12} \mathrm{C}\right)$ is concentrated in the more reduced forms (e.g. methane, organic matter). When marine organisms die, they preferentially remove the lighter isotope $\left({ }^{12} \mathrm{C}\right)$ from the surface ocean, resulting in the shallow ocean having slightly more positive $\delta^{13} \mathrm{C}$ values than the overall ocean. Changes in the $\delta^{13} \mathrm{C}$ of the ocean primarily reflect changes in the size of the terrestrial biosphere, and/or a perturbation in the carbon cycle due to a geological sink/source, such as gas hydrates, volcanic outgassing, organic matter accumulation and sedimentation.

\section{Branched versus Isoprenoid Tetraether (BIT) index}

In concert with the $\mathrm{TEX}_{86}$ measurements described above, the concentration of branched and isoprenoid tetraether lipids were measured in mid-Waipara samples. The branched versus isoprenoid tetraether (BIT) index is based on the ratio of nonisoprenoidal ether lipids, derived from soil, to archaeal ether lipids that are derived from Crenarchaeota (Hopmans et al., 2004). The BIT index is used as a proxy for the relative input of terrestrial and marine organic matter.

\subsection{Sample Material}

The northern Canterbury basin extends from the Ashley River in the south, inland to the Southern Alps, and to the Hope Fault in the north (Browne and Field, 1985). Through the Late Cretaceous and Early Cenozoic, a westerly landmass existed which approximated the present day Southern Alps (Wilson, 1956). At that time, the New Zealand landmass was further to the south than it is today. Paleogeographic reconstructions of New Zealand for the Early Eocene suggest that the New Zealand landmass was situated between $c a .50^{\circ}$ to $60^{\circ}$ south, approximately $10^{\circ}$ further south than the present day (Figure 1.9). 


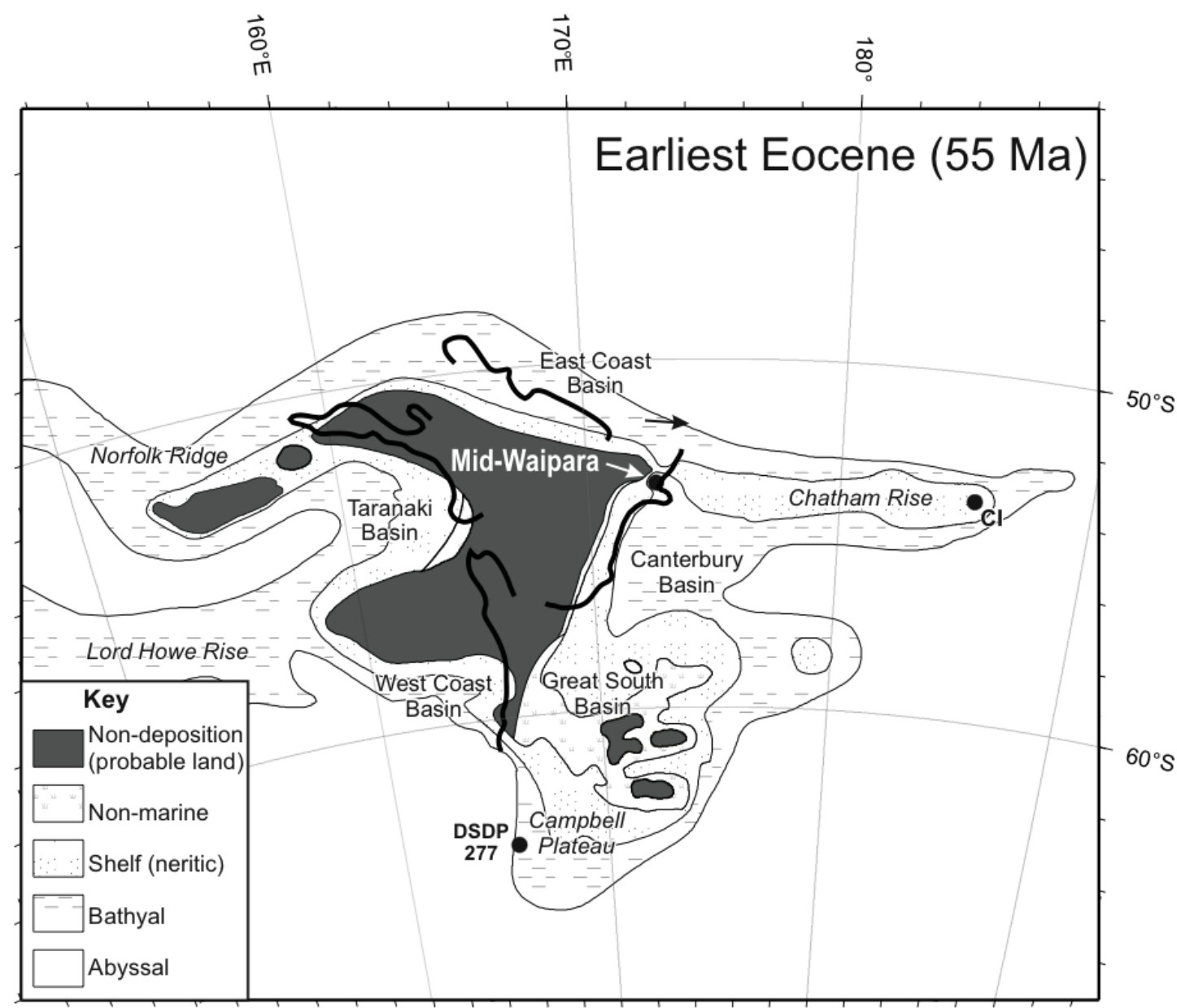

Figure 1.9. Paleogeographic reconstruction of New Zealand in Early Eocene time from Hollis et al. (2009). The mid-Waipara section (indicated) comprises upper bathyal siliciclastic sediments from the northern Canterbury basin.

The basement rocks in the north Canterbury region are of the Torlesse composite terrane, which are unconformably overlain by rocks of the Eyre Group (Figure 1.10) (Browne and Field, 1985; Forsyth et al., 2008). Many stratigraphic sections (>125), scattered throughout northern Canterbury, have been studied spanning the Late Cretaceous to the Early Quaternary. The mid-Waipara River section (Figure 1.9) is amongst the most highly sampled and best exposed of these, comprising a Late Cretaceous to Oligocene sedimentary succession (Figure 1.10). The nature and distribution of sediments from north Canterbury indicates a transgressive shelf setting, with the basin progressively deepening over the Late Cretaceous through to the Early Oligocene from non-marine to shoreface to an outer shelf environment (Wilson, 1963; Browne and Field, 1985; Forsyth et al., 2008). 


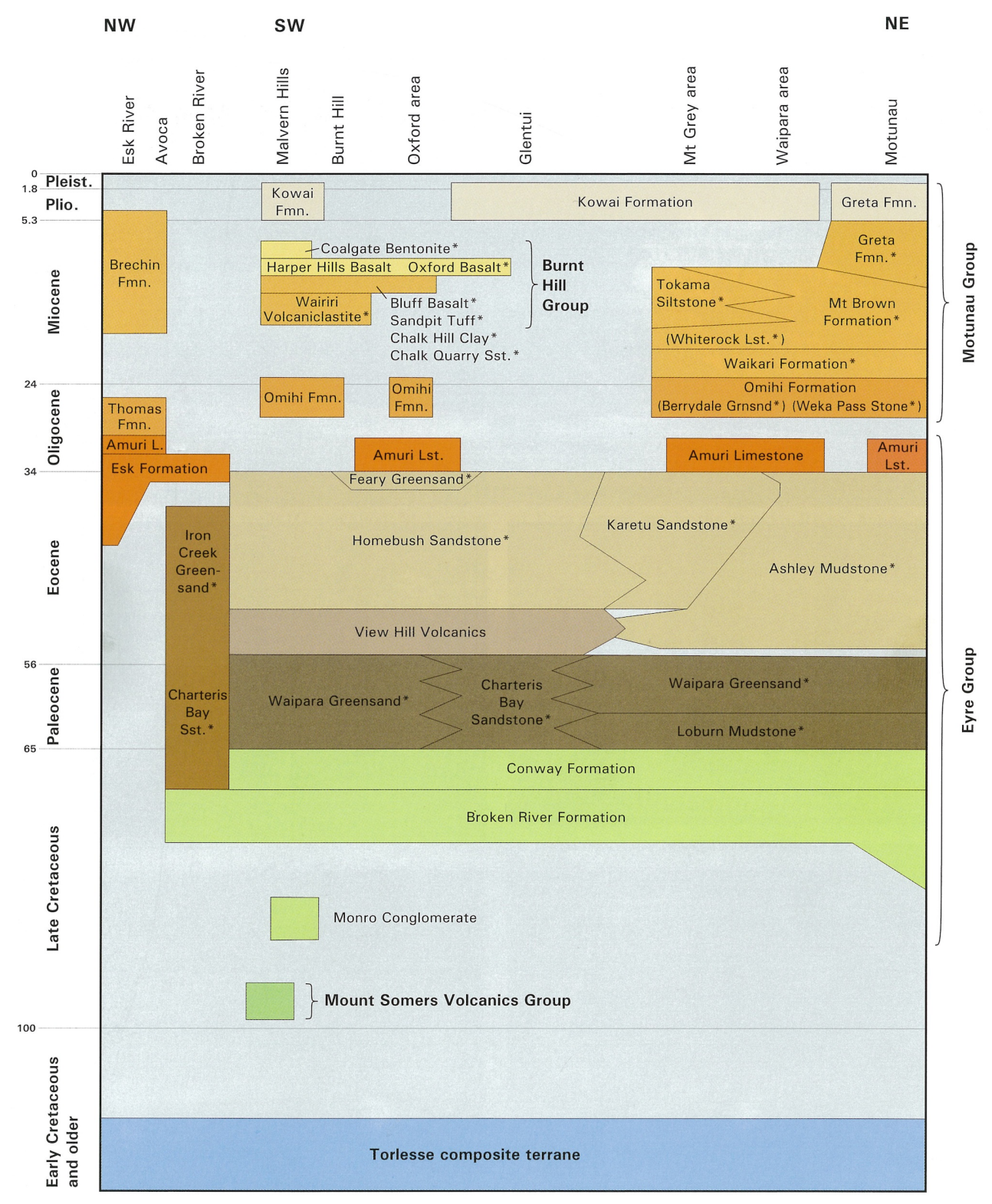

Figure 1.10. Cretaceous and Cenozoic stratigraphy of north Canterbury from Forsyth et al. (2008). The diagram highlights periods of deposition (coloured) and non-deposition or erosion (grey background). The mid-Waipara section is towards the right of the figure.

\subsubsection{The Mid-Waipara River Section}

The Waipara River, north Canterbury, New Zealand, trends northwest-southeast through a Mesozoic-Cenozoic sedimentary succession. The mid-Waipara section (Figure 1.11) is the middle portion of the river downstream from Doctor's Gorge (grid reference M34/7530 9470 on the 1:50,000 New Zealand topographic map series 260; Morgans et al., 2005), and comprises Late Cretaceous (Broken River Formation, Conway Formation), Paleocene (uppermost Conway Formation, Loburn Formation, 
Waipara Greensand), Eocene (?Uppermost Waipara Greensand, Ashley Mudstone, Amuri Limestone) and Oligocene (Amuri Limestone) Eyre Group sediments.

The mid-Waipara sedimentary section has a long history of geological observations and collections dating back to the 1860s, and including some from prominent early New Zealand geologists (Cotton, Haast, Hector, Hutton, McKay and others). In recent years there has been a focus on microfossils, incorporating examinations of foraminifera, calcareous nannoplankton, radiolaria, spore/pollen and dinoflagellate cyst assemblages, that have led to important advances in Late Cretaceous dinoflagellate cyst and spore/pollen biostratigraphy, high-resolution biostratigraphy and geochemistry across the Cretaceous-Paleogene boundary, and Paleogene foraminiferal biostratigraphy (Morgans et al., 2005). Morgans et al. (2005) published a detailed report on the midWaipara section, outlining the stratigraphic succession, previous paleontological and biostratigraphic collections, and the sample collection from 2003 that is used in this thesis. While relevant background is provided here, for more in-depth detail the reader is directed to that work. 


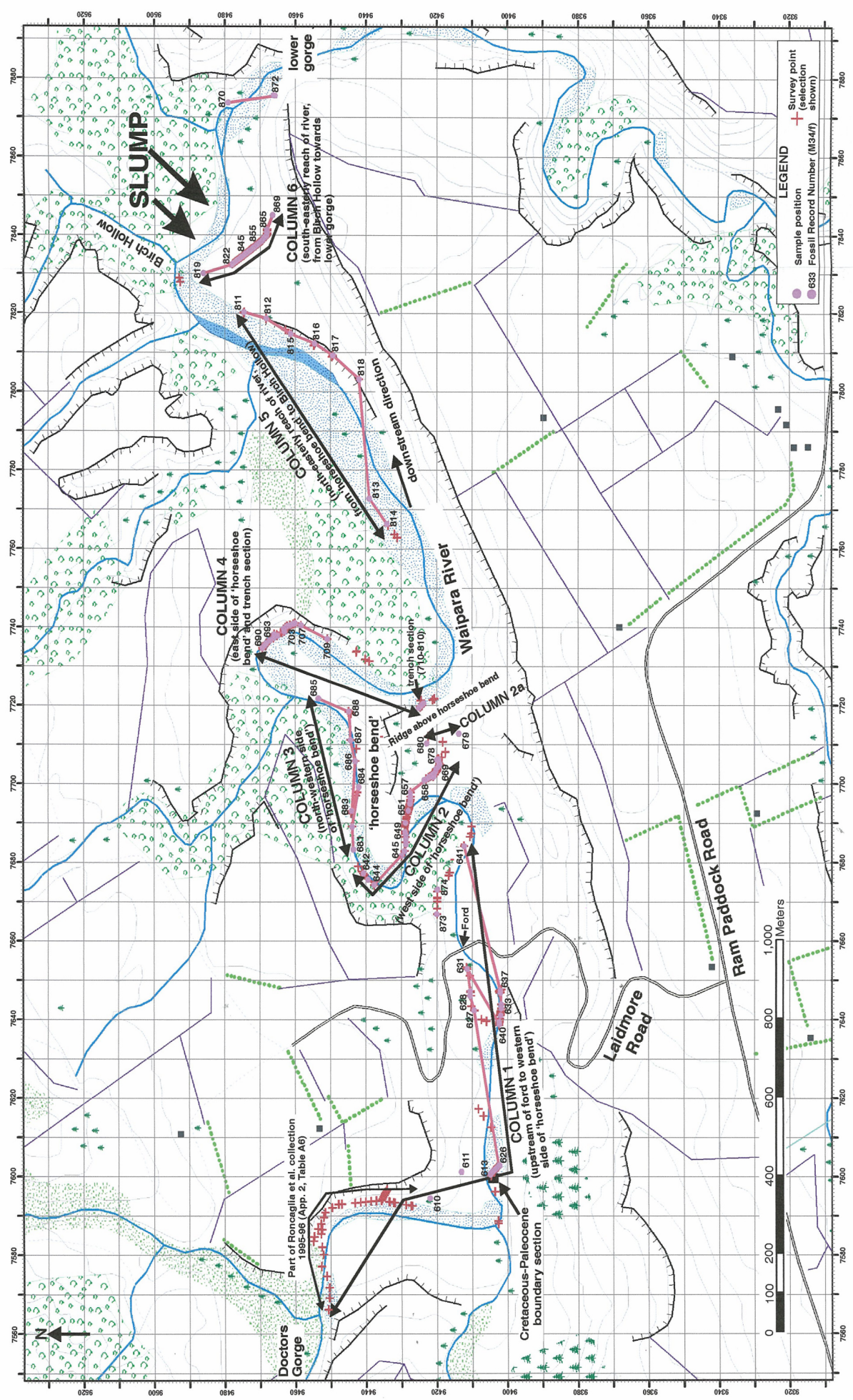

Figure 1.11. The mid-Waipara river section showing the position of the six lithologic columns, 1 to 6 , and the sample suite that was collected during the 2003 GNS survey from Morgans et al. (2005). Column 6 (indicated) is located between the confluence of the Waipara River with Birch Hollow and the 'lower gorge'. The stratigraphic thickness of the column is estimated to be $\sim \mathbf{1 2 3} \mathrm{m}$, consisting of $\sim \mathbf{3 0} \mathrm{m}$ of Waipara Greensand (part) and $\sim 88 \mathrm{~m}$ of Ashley Mudstone. Forty-seven samples of Ashley Mudstone were collected from a good exposure that outcrops on the southwest side of the river bed. 


\section{Sample material}

Note: a complete list of samples from mid-Waipara is given in Appendix 1.

The focus of this study was the Eocene Ashley Mudstone, which outcrops in the mid-Waipara River section. The Ashley Mudstone is a blue-grey to medium green-grey, moderately indurated, calcareous, glauconitic and smectitic mudstone (Browne and Field, 1985). It overlies Waipara Greensand either conformably or disconformably at a burrowed contact, and is conformably overlain by Amuri Limestone (Brown and Field, 1985).

Sampling of the mid-Waipara section was undertaken in February 2003 by scientists from the Institute of Geological and Nuclear Sciences (now GNS Science). The section was divided into six lithologic columns (Figure 1.11), numbered 1 to 6 , representing a stratigraphic progression from westernmost (oldest, Column 1) to easternmost (youngest, Column 6). A well exposed, $60 \mathrm{~m}$ thick section of Ashley Mudstone occurs at Column 6, on the southwest bank of the riverbed, from which 47 samples, MW97 to MW144 (M34/f822 to M34/f869) were collected. Continuous exposure extended no higher than sample MW143 (M34/f868). However, the spot sample MW144 (M34/f869) was collected $10 \mathrm{~m}$ above to determine the age range of the missing interval.

Examination for calcareous nannofossils and radiolaria, and spore/pollen and dinoflagellate cyst assemblages was conducted on approximately half of these samples, and foraminifera were processed from all samples. Paleontological data were used to construct a detailed biostratigraphy of the mid-Waipara section (Morgans et al., 2005; Hollis et al., 2009). Additionally, some material was used for geochemical analysis. Organic biomarker analyses for $\mathrm{TEX}_{86}$ were carried out on 20 mid-Waipara samples, and individual shells of the foraminiferal species Morozovella crater and Cibicides cf. novozelandicus obtained from 13 samples were analysed for oxygen and carbon isotopes (Hollis et al., 2009). These published $\delta^{18} \mathrm{O}$ and $\mathrm{TEX}_{86}$ data appear later in this thesis and are compared and contrasted with the $\mathrm{Mg} / \mathrm{Ca}$ data of the present study.

Bulk samples, sediment residues, microfossil slides and palynology slides are stored at GNS Science, Lower Hutt, New Zealand. 


\section{Biostratigraphy}

Calcareous nannofossils and foraminifera provide the primary age control for the section, and are supplemented with dinocyst and radiolarian bioevents. Detailed biostratigraphy for the mid-Waipara section can be found in Hollis et al. (2009, supplementary information), however the key biostratigraphic markers from that study are listed below.

The base of calcareous nannofossil zone NP13 (50.6 Ma) is identified near the base of the section in sample MW98 (M34/f823) (Hollis et al., 2009). The last occurrence of Discoaster kuepperi, which is dated at $48.6 \mathrm{Ma}$ (Wei, 2004) is well constrained in this section, occurring in sample MW118 (M34/f843) $(87.17 \mathrm{~m})$. The first occurrence of benthic foraminifera Elphidium hampdenense at sample MW113 (M34/f838) marks the base of the Heretaungan Stage, which is dated at 49.5 Ma (Cooper, 2004). Foraminifera indicate that the interval up to MW143 (M34/f868) (113.07 m) is Heretaungan, i.e. older than 46.2 Ma. Dinocyst assemblages also indicate that the upper part of the section lies within the Heretaungan. The spot sample MW144 (M34/f869) collected at 123.1 $\mathrm{m}$ has been assigned to the New Zealand Bortonian Stage (43-37 Ma) (Morgans et al., 2004), based on the first occurrence of the planktonic foraminifer Globigerapsis index. As in many other New Zealand sections (King et al., 1999), there appears to be a significant hiatus in this section, which corresponds to the entire Porangan stage (46.2$43 \mathrm{Ma})$.

For the 49 m-thick section between samples MW97 (M34/f822) (63.69 m) and MW143 (M34/f868) (113.06 m) an age range of 4.5 million years, from 50.7 to 46.2 Ma, with average sedimentation rate of $\sim 12 \mathrm{~cm} / \mathrm{kyr}$ is inferred (Hollis et al., 2009; Figure 1.12). 


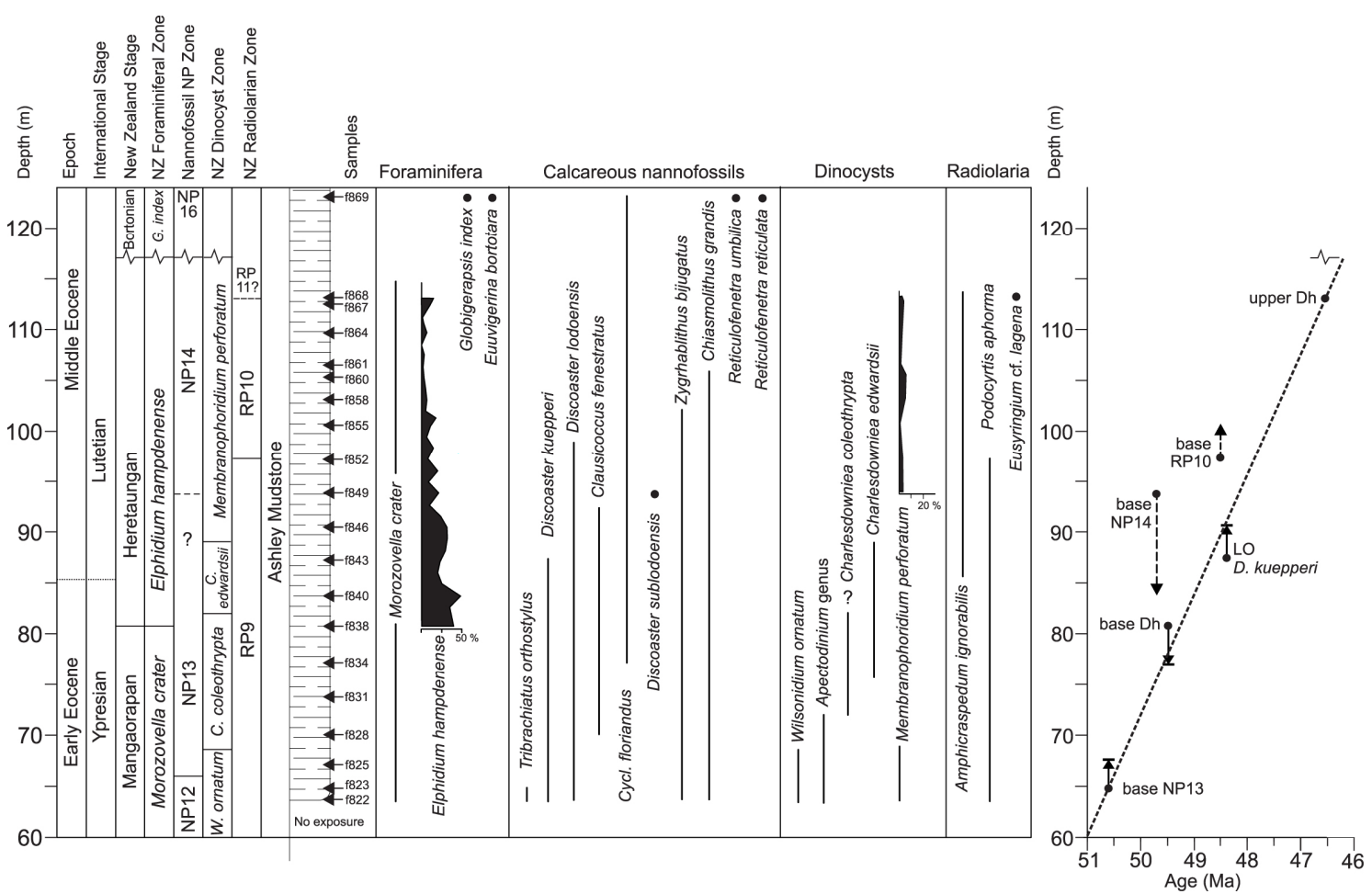

Figure 1.12. Sample locations, biostratigraphy and age model of the Ashley Mudstone sequence from the mid-Waipara River section from Hollis et al. (2009). Correlation with International and New Zealand stages and microfossil zones are based on the stratigraphic ranges of key taxa of foraminifera, calcareous nannofossil, dinocysts and radiolaria. Key biostratigraphic datums are shown in relation to depth $(\mathrm{m})$ and age $(\mathrm{Ma})$ to estimate the duration of the interval studied and average sedimentation rates. Sample names here refer to fossil record file numbers. A complete list of samples is located in Appendix 1.

\section{Paleodepth}

Paleobathymetry at the site has been estimated from the benthic foraminiferal assemblage. A number of key benthic foraminiferal indicators of paleodepth are listed in Table 2.1, which place the site within the lower bathyal zone $(\geq 1000 \mathrm{~m}$; van Morkhoven et al., 1986). It is possible that the paleodepth may be closer to $1500 \mathrm{~m}$ with Tritaxilina zealandica found in 16 of 47 samples, but the Paleogene paleodepth indices in New Zealand are not well calibrated. Other taxa considered to be bathyal dwellers include Cibicidoides truncanus (Cibicides "pre-parki”), Buliminella browni, Allomorphina conica, Chilostomella ovoidea, Kalamopsis grzybowskii, Tritaxia instar, Karreriella chilostoma, Oridorsalis spp., Osangularia spp. and Matanzia sp. The increasing siliceous component through the upper part of the section changes the faunal character, but there is no good evidence for changing paleobathymetry with Tritaxilina zealandica still sporadically present throughout the section. 


\begin{tabular}{|l|c|l|}
\hline Taxa & $\begin{array}{c}\text { Upper } \\
\text { paleodepth (m) }\end{array}$ & Reference \\
\hline Vulvulina zespinosa & 400 & Hayward (1986) \\
\hline Vulvulina spp. & 1000 & Tjalsma \& Lohmann (1983) \\
\hline $\begin{array}{l}\text { Anomalinoides semicribratus } \\
\text { (Anomalina aotea) }\end{array}$ & 200 & Hayward (1986) \\
\hline Anomalinoides semicribratus & 600 & van Morkhoven et al. (1986) \\
\hline Anomalinoides semicribratus & 1000 & Tjalma \& Lohmann (1983) \\
\hline Nuttallides carinotruempyi & 400 & Hayward (1986) \\
\hline Nuttallides truempyi & 500 & van Morkhoven et al. (1996) \\
\hline Nuttallides truempyi & 1000 & Tjalma \& Lohmann (1983) \\
\hline $\begin{array}{l}\text { Anomalinoides capitatus } \\
\text { (Anomalina visenda) }\end{array}$ & Bathyal-abyssal & van Morkhoven et al. (1986) \\
\hline Anomalinoides capitatus & 1000 & Tjalma \& Lohmann (1983) \\
\hline $\begin{array}{l}\text { Cibicidoides eocenica } \\
\text { (Cibicides collinsi) }\end{array}$ & 1000 & Tjalma \& Lohmann (1983) \\
\hline Pleurostomella spp. & 1000 & Hayward \& Buzas (1979) \\
\hline Stilostomella spp. & 1000 & Tjalma \& Lohmann (1983) \\
\hline Tritaxilina zealandica & 1500 & Hayward (1986) \\
\hline
\end{tabular}

Table 1.1. Key benthic foraminifera used in paleobathymetric interpretation with uppermost paleodepth and main reference. Taxa in brackets are local synonyms.

\section{Oceanicity}

In shelf sediments, foraminiferal assemblages are comprised of an indigenous benthic component and an allochthonous planktonic component sedimented from the water column above, which may be transported from an oceanic source. The relative abundance of planktonic to benthic foraminifera (planktonic / planktonic + benthic as a percentage) can be used to determine the proximity of marginal seas to an ocean (Murray, 1976). In the mid-Waipara samples, the lower part of the section (MW97 MW105) had an average planktonic abundance of $75 \%$, indicating a sub-oceanic to fully oceanic watermass existed above the site of deposition. For most of the remaining section (MW106 - MW131) the planktonic abundance is halved, averaging 38\%, which suggests an outer neritic watermass during that time. The upper part of the section (MW132 - MW143) has a considerably reduced planktonic component, averaging just $10 \%$, representing an inner neritic watermass. These figures indicate that the oceanic connection to the site of deposition was significantly reduced through the middle Eocene. 


\section{Foraminifera preservation}

The degree of preservation of foraminifera from mid-Waipara degrades markedly upward through the section, as documented by scanning electron microscope (SEM) images (Appendix 2, Chapter 3). In the lower part of the section, pores and ornamentation are preserved on surfaces, and microgranular layering appears to be preserved in walls. In the upper part of the section, recrystallisation has resulted in the loss of some surface features and wall structures. In general, benthic taxa are better preserved than planktonic taxa, although at the top of the section, even robust benthic tests appear to have been affected. Such severely disturbed specimens would generally hold little value for use in geochemical analysis. However, in situ LA-ICP-MS analysis is explored here as a tool that might usefully recover reliable $\mathrm{Mg} / \mathrm{Ca}$ sea temperatures from these variably preserved Eocene foraminifera.

\section{This study}

Selected foraminifera taxa were picked from 20 of the 47 faunal slides from the Ashley Mudstone for use in this study. A total of 13 species of foraminifera separated from mid-Waipara sediments have been analysed in this study comprising 5 planktonic species (Morozovella crater, M. lensiformis, Acarinina primitiva, A. collactea and Globanomalina wilcoxensis) and 8 benthic species (Elphidium hampdenense, Anomalina visenda, Nuttallides carinotruempyi, C. pre-parki, C. kurinuia, C. collinsi, Vaginulinopsis marshalli and Bulimina subbortonica). C. kurinuia is an informal manuscript name, and thus kurinuia is deliberately not italicised.

Plate 1.1. SEM images of the $\mathbf{1 3}$ species of foraminifera studied from mid-Waipara, scale bar $50 \mu \mathrm{m}$. (a - e) are planktonic taxa, and (f - m) are benthic taxa. (a) Morozovella crater. (b) M. lensiformis. (c) Acarinina primitiva. (d) A. collactea. (e) Globanomalina wilcoxensis. (f) Elphidium hampdenense. (g) Anomalina visenda. (h) Nuttallides carinotruempyi. (i) Cibicides pre-parki. (j) C. kurinuia. (k) C. collinsi. (l) Vaginulinopsis marshalli. (m) Bulimina subbortonica. Note these specimens are from the lower part of the stratigraphic column where the foraminifera preservation is generally better than in the upper part. 


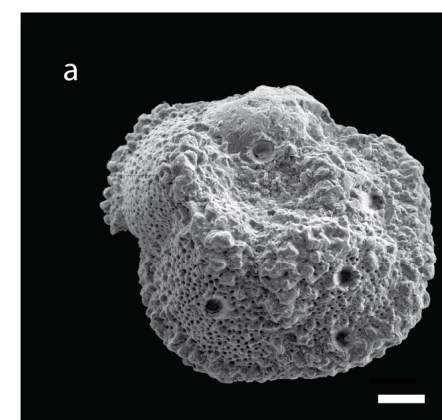

b
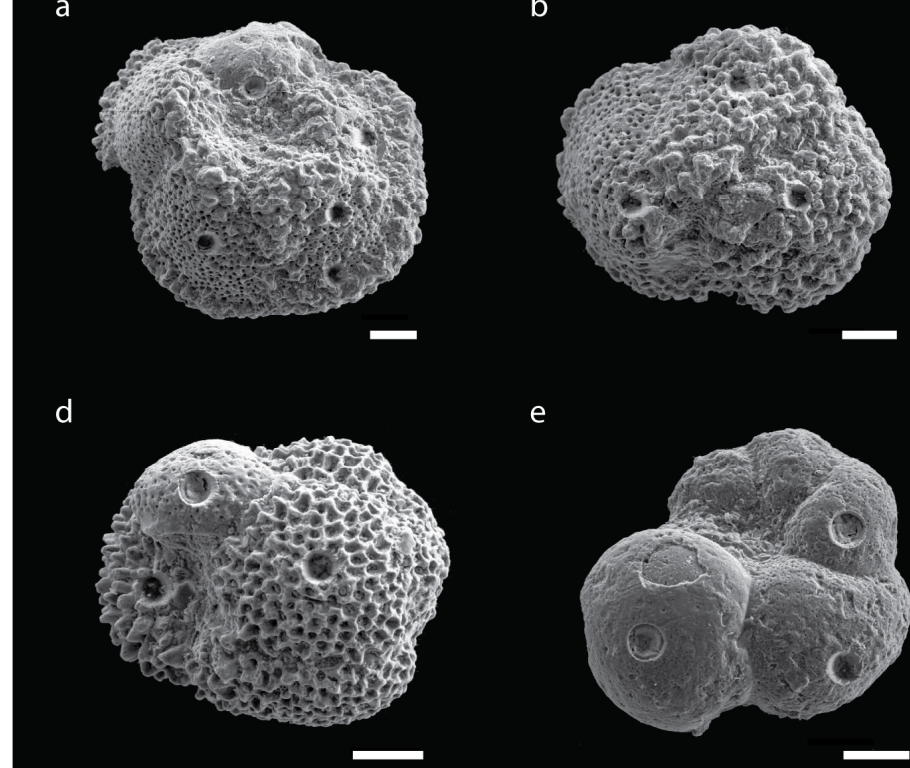

e

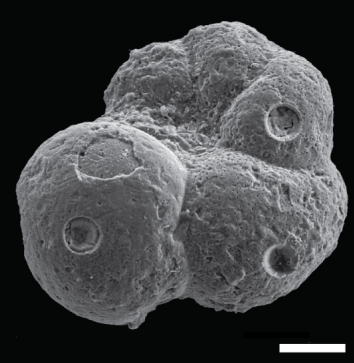

C

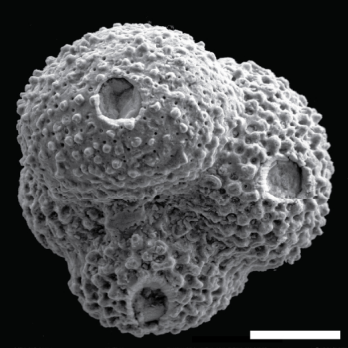

g

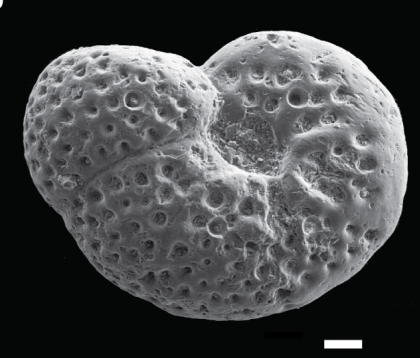

h

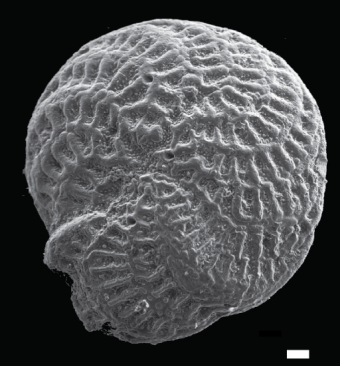

ש
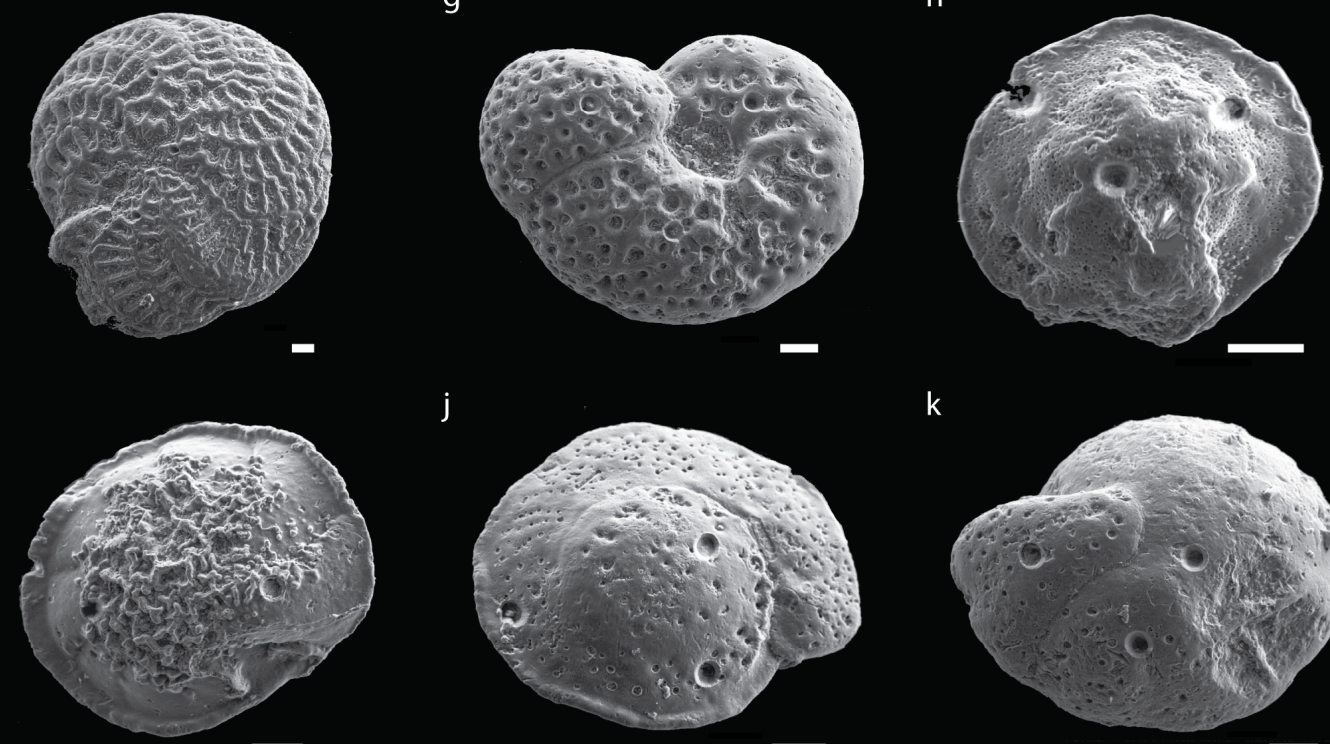

j

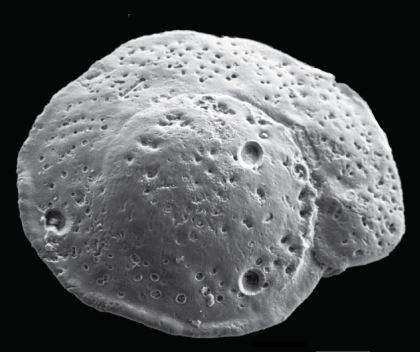

k

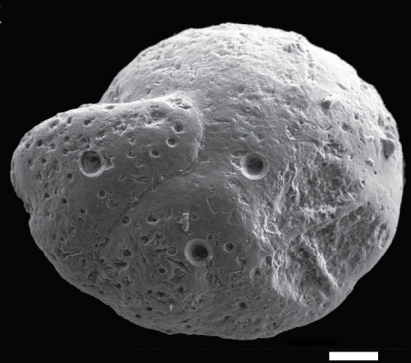

I

$m$
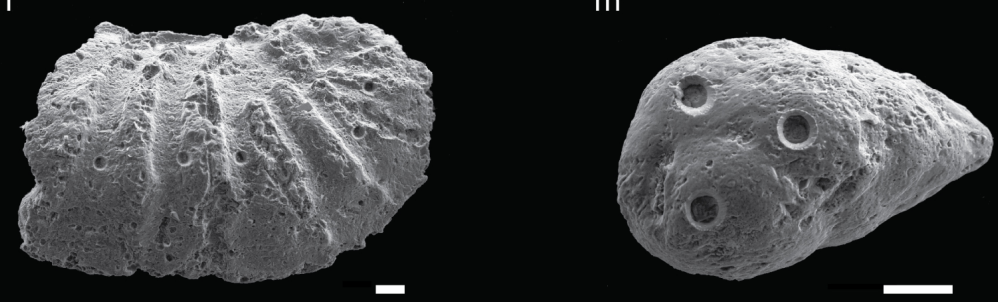


\subsubsection{Foraminifera ecology}

The foraminifera used in this study lived in a variety of habitats, which has implications for paleotemperature interpretation. Knowledge of the ecology of Eocene foraminifera is limited, and largely based on stable isotope data and inferences from morphology and antecedent taxa.

Morozovellids are generally accepted as warmer water indicators and are common in (sub)tropical areas. Oxygen and carbon isotopes indicate a surface mixed layer habitat for the Morozovellids (Berggren and Pearson, 2006; Boersma et al., 1987; Quilléveré et al., 2001). Acarinina collactea is a cosmopolitan taxa, recorded in excess of $50^{\circ}$ in both hemispheres, while Acarinina primitiva is essentially a temperate, high latitude taxa with an austral-subantarctic distribution (Berggren et al., 2006), and most Acarininid taxa are considered to be mixed-layer dwellers with carbon isotopes suggesting a photosymbiotic life habitat (Quilléveré et al., 2001; Berggren et al., 2006). Pseudohastigerina wilcoxensis has a global distribution in the mid- to high-latitudes. Studies on Pseudohastigerina taxa suggest a shallow surface water habitat (Poore and Matthews, 1984). Subbotinids are thermocline dwellers, and are taken to represent temperatures at a depth of $\sim 400 \mathrm{~m}$ (Pearson et al., 2006).

Hayward et al. (1997) consider Elphidium to have been mostly free-living in sediments, but sometimes adopted a clinging lifestyle, and were predominantly herbivores (pinnate diatoms) although they were sometimes detrivorous. Bulimina is considered to have been an infaunal taxa, and Vaginulinopsis (elongate nodosariid) is expected to have had a similar habitat. Rotaline specimens such as Cibicides and Nuttallides with flattened sides or with some sculpture may have had some attaching epifaunal habitat either above or on the sediment water interface. Note that in this upper bathyal setting, seafloor temperatures are though to represent intermediate water (Hollis et al., 2009) 


\section{METHODS}

To-date, most applications of the $\mathrm{Mg} / \mathrm{Ca}$ paleothermometer have utilized bulk analytical methods where multiple foraminifera are crushed, chemically cleaned with oxidizing and/or reducing agents, dissolved in acid and then analysed in solution. These methods involve careful cleaning procedures to remove potential contaminant phases and detritus that may affect the measured test chemistry and potentially result in calculation of erroneous paleo-sea temperatures. Bulk analysis of multiple foraminifera yields a single temperature for a sample. In this study, we have used a relatively new technique called laser ablation inductively coupled plasma mass spectrometry (LA-ICPMS) to ablate material from foraminifera at a spatial resolution of a few tens of microns, which has the potential to yield more information than bulk methods, as well as overcome some of the issues described above (Section 1.4.1).

\subsection{Sample Preparation}

\subsubsection{Foraminifera Separation}

Forty-seven mid-Waipara samples were processed for foraminifera. Bulk rock was dried at $40^{\circ} \mathrm{C}$, and $500 \mathrm{~g}$ was washed over a $75 \mu \mathrm{m}$ screen, dried at $40^{\circ} \mathrm{C}$, and the residue weighed. Residues were split repeatedly with a Carpco microsplitter to get census counts on sediment ( $>50-100$ grains) $>150 \mu \mathrm{m}$ in size. Foraminiferal abundance was determined and splits reconstituted to get a foraminiferal count of $>100$ specimens in the $>150 \mu \mathrm{m}$ fraction, which gives a planktonic/benthic ratio and foraminiferal productivity. For each sample, half the remaining residue was exhaustively picked onto a faunal slide, which yield biostratigraphic and paleodepth data (Section 1.5.1). Selected taxa were then picked from faunal slides and prepared for LA-ICP-MS trace element analysis.

\subsubsection{Foraminifera Cleaning and Mounting}

Prior to LA-ICP-MS analysis, foraminifera tests were cleaned to remove loosely adhering clay and other detrital material, as well tragacanth gum used to glue specimens to faunal slides, by repeated rinsing in ultra-pure $(>18 \mathrm{M} \Omega)$ water and analytical reagent 
(AR) grade methanol. The cleaning procedure did not include an ultrasonication step, as these Eocene specimens were found to easily disintegrate, and given the small number of specimens available, the risk of sample loss outweighed the potential benefit of removing small amounts of adhered/infilling material. After cleaning, individual foraminifera were mounted on double-sided tape attached to the surface of a wafer of National Institute of Standards and Technology standard NIST610, a silicate glass reference material which has been spiked with up to 61 trace elements at nominal concentrations of $500 \mu^{g_{~ g}}{ }^{-1}$ (Plate 2.1; Pearce et al., 1997; Jochum and Stoll, 2008).

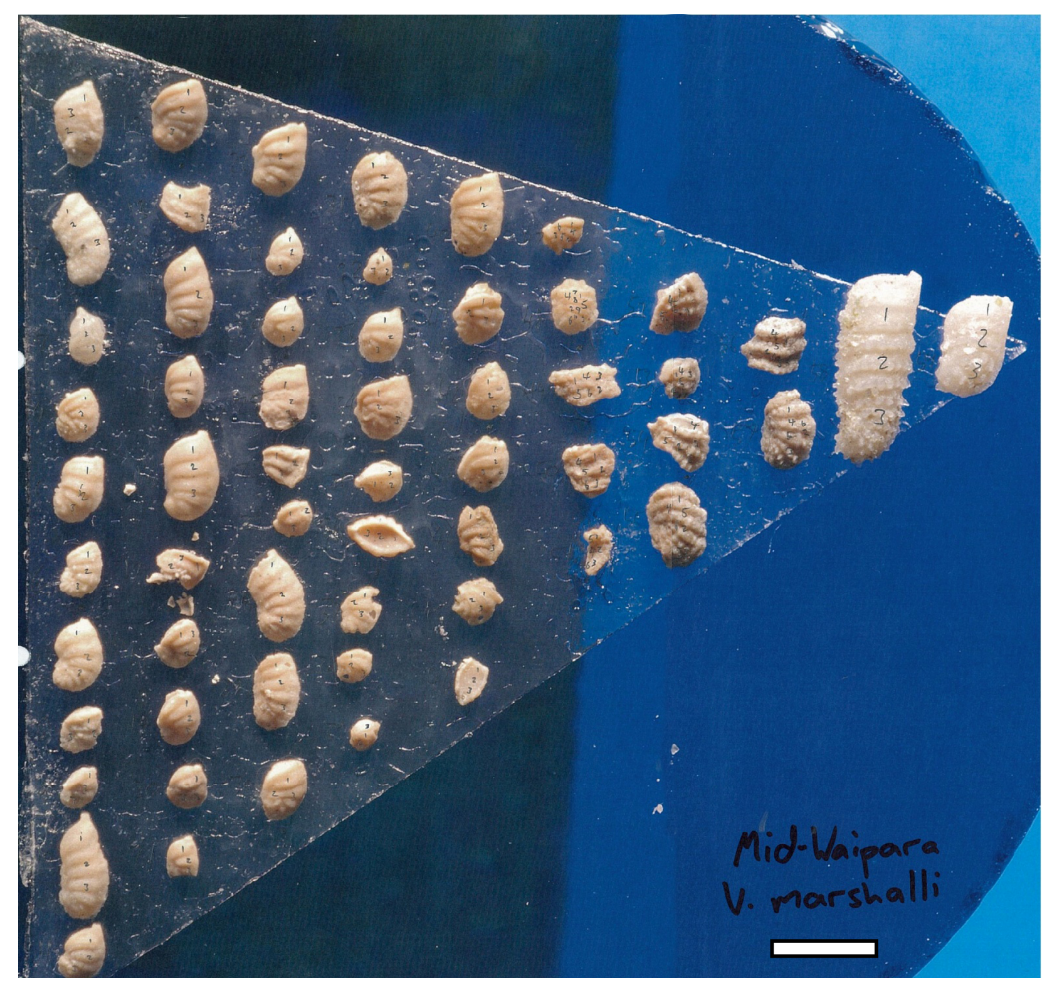

Plate 2.1. Specimens of $V$. marshalli prepared for LA-ICP-MS analysis, having been cleaned and mounted onto double sided tape attached to a wafer of NIST610 silicate glass standard. Each specimen was ablated at least 3 times, and in some cases as many as 10 times. Scale bar $=1 \mathrm{~mm}$.

\subsection{LA-ICP-MS Trace Element Analysis}

Foraminifera were ablated with a New Wave $193 \mathrm{~nm}$ laser ablation system with a spot size of $25 \mu \mathrm{m}$, laser repetition rate of 2 or $3 \mathrm{~Hz}$ and laser power of $\sim 50 \%$. Under these conditions, a laser ablation pit is gradually ablated at a rate of $\sim 0.2$ to $0.3 \mu \mathrm{m} \mathrm{s}^{-1}$, yielding a trace element depth profile through the test. Ablation was completed in a helium atmosphere and ablated material carried to the ICP-MS in a helium-argon gas mixture. Laser ablation sites were identified by examining foraminifera under a video 
camera attached to the laser ablation system, and recorded on a photograph of the prepared slide.

An Agilent 7500CS ICP-MS was used to measure trace element abundances relative to Ca during ablation. The isotopes ${ }^{24} \mathrm{Mg},{ }^{27} \mathrm{Al},{ }^{43} \mathrm{Ca},{ }^{55} \mathrm{Mn},{ }^{66} \mathrm{Zn},{ }^{88} \mathrm{Sr}$ and ${ }^{138} \mathrm{Ba}$ were sequentially and repeatedly monitored during ablation with dwell times of $10 \mathrm{~ms}$. Instrumental backgrounds of $60 \mathrm{~s}$ were determined prior to each analysis, which was typically $120 \mathrm{~s}$ long. Analyses of the NIST610 glass were interspersed between every 5 - 10 analyses of foraminifera to correct for trace element fractionation induced by the laser ablation and mass spectrometry procedures. Typical foraminifera (foram) and background (bg) rates (cps) were: ${ }^{24} \mathrm{Mg}_{\text {foram }}=60000,{ }^{24} \mathrm{Mg}_{\mathrm{bg}}=300 ;{ }^{27} \mathrm{Al}_{\text {foram }}=160000$ ,${ }^{27} \mathrm{Al}_{\mathrm{bg}}=5000 ;{ }^{43} \mathrm{Ca}_{\text {foram }}=42000,{ }^{43} \mathrm{Ca}_{\mathrm{bg}}=300 ;{ }^{55} \mathrm{Mn}_{\text {foram }}=14000,{ }^{55} \mathrm{Mn}_{\mathrm{bg}}=5000$; ${ }^{66} \mathrm{Zn}_{\text {foram }}=700,{ }^{66} \mathrm{Zn}_{\text {bg }}=40 ;{ }^{88} \mathrm{Sr}_{\text {foram }}=85000,{ }^{88} \mathrm{Sr}_{\mathrm{bg}}=20 ;{ }^{138} \mathrm{Ba}_{\text {foram }}=8000,{ }^{138} \mathrm{Ba}_{\mathrm{bg}}=$ 20 .

After trace element analysis, the double sided tape was transferred to an aluminium stub and carbon coated, and foraminifera were imaged by scanning electron microscopy (SEM). Images of foraminifera with laser pits were compared to their respective trace element depth profiles for the interpretation of spectra, as well assessment of test preservation.

\subsection{Data Processing}

\subsubsection{Trace Element Depth Profiles}

Trace element data were processed offline, whereby element/Ca ratios were plotted versus ablation time, producing a depth profile of foraminifera test chemistry from its exterior through to the interior (Figure 2.2). Trace element profiles were screened for the effects of diagenesis and contamination. Most profiles show an enriched zone of high $\mathrm{Mg} / \mathrm{Ca}$ and other trace elements at the start of each analysis (outer test wall), followed by an interval of relatively constant and lower $\mathrm{Mg} / \mathrm{Ca}$, consistent with observations reported in previous in situ geochemical investigations of foraminifera (e.g. Eggins et al., 2003; Reichart et al., 2003; Pena et al., 2005; Sadekov et al., 2008). Zones of high $\mathrm{Mg} / \mathrm{Ca}$ are typically also marked by high $\mathrm{Mn} / \mathrm{Ca}, \mathrm{Al} / \mathrm{Ca}$ and $\mathrm{Ba} / \mathrm{Ca}$. Ablating further into the interior resulted in a return to high $\mathrm{Mg} / \mathrm{Ca}$ values, indicating that the laser has penetrated the inner wall of the test and is ablating some other phase 
such as diagenetic calcite, infilling detrital material or secondary minerals. Alternatively, if the test was hollow counts would drop and the depth profile would be mostly noise.

The power of spatially resolved analytical methods like LA-ICP-MS is in the fact that enriched zones or other phases can be excluded, and just the part of the profile that represents the primary calcite is averaged. Thus, element/Ca ratios (i.e. the $\mathrm{Mg} / \mathrm{Ca}$ that is used for temperature calculations) are integrated only from the zone of constant, regular element/Ca ratios in the depth profiles (Figure 2.2). Depth profiles were checked manually, and the integrated portion was selected from each profile. Analyses were identified as good, fair, short, bad, high $\mathrm{Al} / \mathrm{Ca}$, etc. Several examples of different types of trace element depth profiles are given in Figure 2.2, and trace element profiles for every analysis included in this thesis are present in Appendix 2.

Screening of analyses was very conservative, and typically only those with good or fair profiles, or relatively regular short profiles, were used for temperature determinations. Summary trace element data was also scrutinized, and analyses with unusual values in any trace element/Ca ratio were also discarded. Sample averages and standard deviations for each trace element were calculated from the data that passed all of the screening tests. 

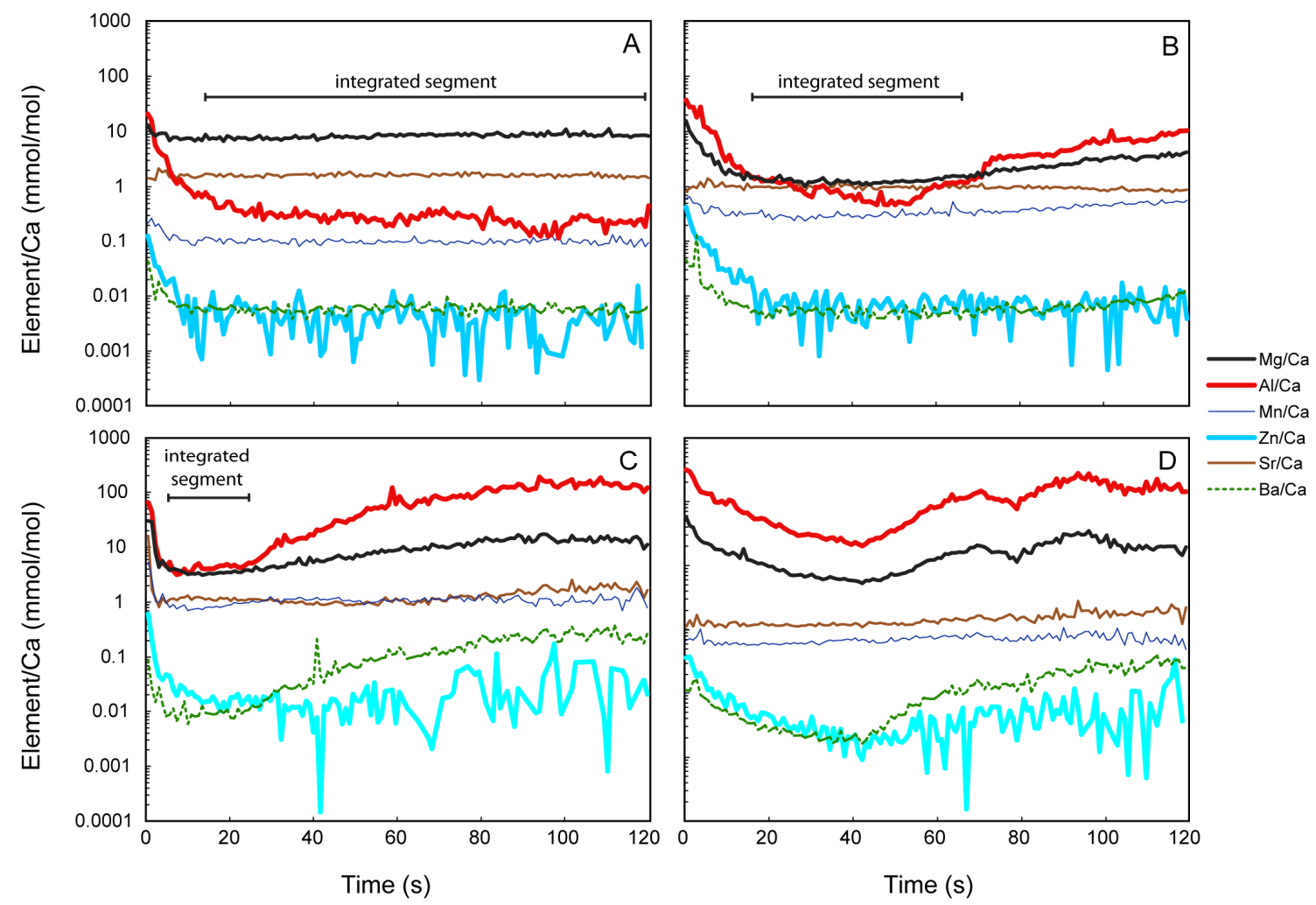

Figure 2.1. Examples of LA-ICP-MS trace element depth profiles showing the different types of profiles through foraminifera test walls and how these are screened to yield reliable $\mathrm{Mg} / \mathrm{Ca}$ data. The lower scale on the profiles is ablation time, which corresponds to a depth of ca. 0.2-0.3 $\mu \mathrm{m} \mathrm{s}^{-1}$. In profiles (A - C) a surface veneer that is enriched in trace elements is clearly visible. This is followed by an interval of variable thickness characterized by low and relatively constant $\mathrm{Mg} / \mathrm{Ca}$, which is interpreted to be the part of the profile reflecting primary foraminiferal calcite chemistry that is averaged for the calculation of $\mathrm{Mg} / \mathrm{Ca}$ paleotemperatures. The deeper part of most profiles typically shows a return to higher trace element/Ca values that may indicate that the laser is ablating material infilling chambers or secondary minerals. (A) an example of a 'good' profile where the segment that can be used for temperature determination comprises most of the analysis, which was typical of the benthic species $V$. marshalli, but was less common for other taxa; (B) a 'fair' profile where the usable segment is perhaps half of the analysis, which was common amongst most species analysed in this study; (C) a 'short' profile typical of the more delicate benthic species such as $B$. subbortonica where only a limited part of the profile represents the primary trace element signal of the foraminiferal calcite; (D) an example of a 'bad' profile that would not be used in this study, as was the case for a significant number of analyses of planktonic taxa, particularly towards the top of the midWaipara section.

Depth profiles were found to vary significantly between species due to varying properties (thickness, density, etc.) of tests from different taxa, and between analyses relating to the positioning of laser pits. For example, the good portions of a profile might be very short if the laser penetrated more quickly, or very irregular if the laser happened to ablate an angled surface or some ornamentation. Benthic species generally yield better laser ablation profiles as a result of more effective ablation of their denser, 
less porous, less ornamented, and flatter tests. Some species (e.g. V. marshalli) consistently produced long, regular depth profiles, of which the integrated segment comprised most of the analysis. These factors were used to identify species that are most suitable for this type of analysis.

\subsubsection{Data Screening}

After screening of depth profiles, summary trace element data was scrutinized, and analyses with anomalously high values in any trace element were also discarded. Unscreened data was also found to show a linear correlation between $\mathrm{Mg} / \mathrm{Ca}$ and $\mathrm{Al} / \mathrm{Ca}$, which reflects the influence of silicate contamination, interpreted as small amounts of sediment infilling pores. Following Barker et al. (2003), the composition of the contaminant can be approximately determined by plotting $\mathrm{Mg} / \mathrm{Ca}$ versus $\mathrm{Al} / \mathrm{Ca}$, from which the slope of a linear regression gives the $\mathrm{Al} / \mathrm{Mg}$ ratio of the sediment (Figure 2.2). Once the contaminant composition is known, the related excess in $\mathrm{Mg} / \mathrm{Ca}$ can be calculated from

$$
\mathrm{Mg} / \mathrm{Ca}_{\text {(excess) }}=\mathrm{Al} / \mathrm{Ca}_{\text {(sample) }} / \mathrm{Al} / \mathrm{Mg}_{\text {(contaminant) }}
$$

equation 2.1

Screening limits for silicate contamination were thus be set by calculating the $\mathrm{Al} / \mathrm{Ca}$ ratio at which the $\mathrm{Mg} / \mathrm{Ca}$ excess would be sufficient to bias temperatures by $>1^{\circ} \mathrm{C}$ based on the equation of Barker et al. (2003),

$$
\mathrm{Al} / \mathrm{Ca}_{\text {(limit) }}=\mathrm{Mg} / \mathrm{Ca} \mathrm{(excess)} \times \mathrm{Al} / \mathrm{Mg}_{\text {(contaminant) }}
$$

The sediment composition from the mid-Waipara samples was determined from a plot of all unscreened data from all species, excluding only analyses with extreme values of $\mathrm{Al} / \mathrm{Ca}(>50 \mathrm{mmol} / \mathrm{mol}$; Figure 2.2). This yielded an $\mathrm{Al} / \mathrm{Mg}$ ratio of 8.1 (i.e. much less Mg-rich than the sediment in Barker et al. (2003)) from which screening limits were calculated for each species. 


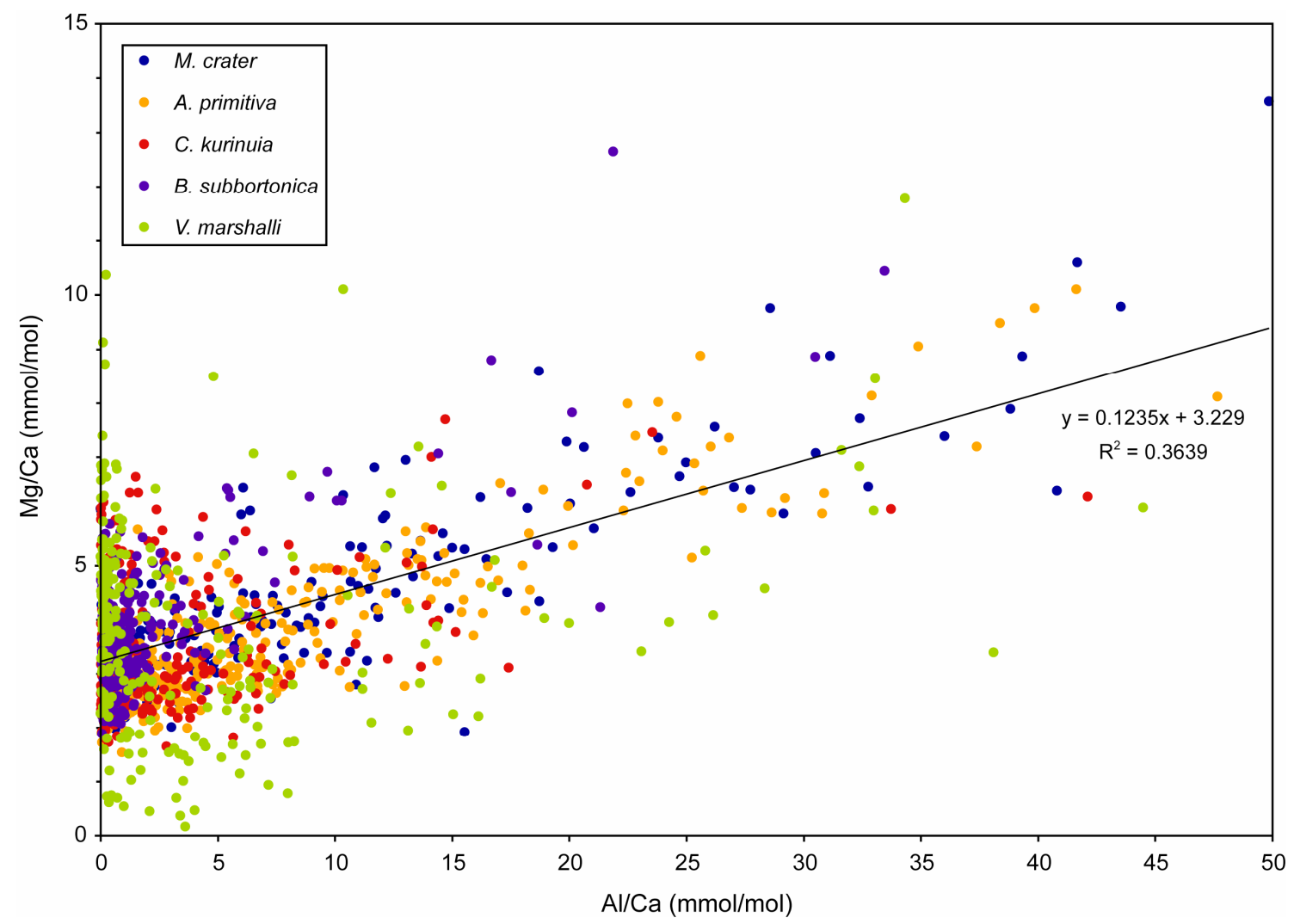

Figure 2.2. Unscreened $\mathrm{Mg} / \mathrm{Ca}-\mathrm{Al} / \mathrm{Ca}$ data for 5 main species, excluding analyses with extreme values for $\mathrm{Al} / \mathrm{Ca}(>50 \mathrm{mmol} / \mathrm{mol})$, which is used to approximately determine the contaminant composition. A linear regression is fitted to the data, the slope of which give the approximate $\mathrm{Mg} / \mathrm{Al}$ ratio of the contaminant phase. The $\mathrm{Al} / \mathrm{Mg}$ ratio used in the equation of Barker et al. (2003) is $1 /$ slope of this regression (i.e. $\mathrm{Al} / \mathrm{Mg}=1 / 0.1235=8.094$ ).

The screening limit also depends on the calibration used (i.e. planktonic or benthic) and the typical $\mathrm{Mg} / \mathrm{Ca}$ ratio for each species. For example, the planktonic species $M$. crater has a typical $\mathrm{Mg} / \mathrm{Ca}$ value of ca. $3.6 \mathrm{mmol} / \mathrm{mol}$. Based on the planktonic calibration, an increase of $9 \%(0.325 \mathrm{mmol} / \mathrm{mol}) \mathrm{Mg} / \mathrm{Ca}$ would increase the calculated temperature by $1{ }^{\circ} \mathrm{C}$. Based on equation 2.2 , the required limit for $\mathrm{Al} / \mathrm{Ca}$ in this case is $0.325 \times 8.1=2.6 \mathrm{mmol} / \mathrm{mol}$. Screening limits for the species used in the temperaturetime record are given in Table 2.1. 


\begin{tabular}{lccc}
\hline & $\begin{array}{c}\text { Typical } \\
\mathrm{Mg} / \mathrm{Ca} \\
(\mathrm{mmol} / \mathrm{mol})\end{array}$ & $\begin{array}{c}\text { Sensitivity } \\
(\mathrm{Mg} / \mathrm{Ca} \\
\mathrm{mmol} / \mathrm{mol} \\
\left.=+1^{\circ} \mathrm{C}\right)\end{array}$ & $\begin{array}{c}\mathrm{Al} / \mathrm{Ca} \\
\text { screening } \\
\text { limit } \\
(\mathrm{mmol} / \mathrm{mol})\end{array}$ \\
\hline M. crater & 3.6 & 0.33 & 2.6 \\
A. primitiva & 3.1 & 0.28 & 2.3 \\
C. kurinuia & 3.4 & 0.31 & 2.5 \\
B. subbortonica & 4.0 & 0.44 & 3.5 \\
V. marshalli & 8.2 & 0.90 & 7.2 \\
\hline
\end{tabular}

Table 2.1. Silicate contamination screening limits on $\mathrm{Al} / \mathrm{Ca}$ for the 5 species used in the temperature-time record. Screening limits were calculated from a contaminant $\mathrm{Al} / \mathbf{M g}$ ratio of 8.094. After screening with these limits, no $\mathrm{Mg} / \mathrm{Ca}$ temperatures should be overestimated by $>1^{\circ} \mathrm{C}$ as a result of sediment contamination.

When the data are screened in this way, no analysis should overestimate temperature by more than $1{ }^{\circ} \mathrm{C}$. Note that in the preliminary study (Chapter 3 ) data for all planktonic species were screened at $\mathrm{Al} / \mathrm{Ca}$ ratios of $4 \mathrm{mmol} / \mathrm{mol}$, and all benthics at 3 $\mathrm{mmol} / \mathrm{mol}$.

\subsection{Paleotemperature Determinations}

\subsubsection{Mg/Ca Temperature Parameters}

Temperatures were calculated using equation 1.1 (Chapter 1.4.1). The parameters and issues described in Chapter 1.4.1 are addressed here, in the context of this study.

1- Temperature calculations for planktonic taxa were made using a multi-species $\mathrm{Mg} / \mathrm{Ca}$-temperature calibration for modern tropical and sub-tropical planktonic foraminifera from a sediment trap time series $(A=0.38, B=0.09$; Anand et al., 2003). Benthic temperatures were calculated using a core-top calibration from three modern Cibicidoides species $(A=0.867, B=0.109$; Lear et al., 2002).

2- Interspecies calibration factors for planktonic taxa were computed based on the species $M$. crater. However, as the planktonic calibration is a multi-species calibration, the interspecific differences between planktonic taxa were not significant. For benthic species, larger systematic differences were observed. Benthic taxa were normalized to the species $C$. kurinuia, which is the same genus as the species on which the modern calibration was based.

3- Given that Eocene seawater is likely to have had lower $\mathrm{Mg} / \mathrm{Ca}$ than the present day (Wilkinson and Algeo, 1989; Hardie, 1996; Stanley and Hardie, 1998; Zimmermann, 2000; Lowenstein et al., 2001, 2003; Dickson, 2002; Lear et al., 2002), 
sea temperatures have been calculated using a conservative estimate of Eocene seawater $\mathrm{Mg} / \mathrm{Ca}$ of $3.35 \mathrm{mmol} / \mathrm{mol}$, or $35 \%$ lower than the present day value of $5.16 \mathrm{mmol} / \mathrm{mol}$ (Lear et al., 2002). Estimates of Eocene seawater extend to lower values, and as lowering seawater $\mathrm{Mg} / \mathrm{Ca}$ has the effect of increasing calculated $\mathrm{Mg} / \mathrm{Ca}$ temperatures, these temperature estimates are considered to be minimum values.

4- Preservation of primary $\mathrm{Mg} / \mathrm{Ca}$ ratios is not easy to confirm. Many of the factors described previously (section 1.4.1) predominantly affect test surfaces, and are largely circumvented by the choice of analytical method used in this thesis. No proxy is without complications, and ultimately the confidence in reconstructions comes from the agreement between multiple proxies. As such data from other proxies exist for the same samples (Hollis et al., 2009), it is possible to assess whether this approach has been successful, which is discussed later in this thesis. 


\title{
3. EOCENE SEA TEMPERATURES FOR THE MID-LATITUDE SOUTHWEST PACIFIC FROM Mg/Ca RATIOS IN PLANKTONIC AND BENTHIC FORAMINIFERA
}

Note: This chapter has been prepared for submission to the journal Earth and Planetary Science Letters, which has a word limit of 6500 words, and has been formatted to suit the requirements for that journal.

\begin{abstract}
We have used laser ablation inductively coupled plasma mass spectrometry (LAICP-MS) to measure elemental ( $\mathrm{Mg} / \mathrm{Ca}, \mathrm{Al} / \mathrm{Ca}, \mathrm{Mn} / \mathrm{Ca}, \mathrm{Zn} / \mathrm{Ca}, \mathrm{Sr} / \mathrm{Ca}, \mathrm{Ba} / \mathrm{Ca}$ ) ratios of 13 species of variably preserved early to middle Eocene planktonic and benthic foraminifera from New Zealand. The foraminifera were obtained from Ashley Mudstone, Mid-Waipara River, South Island, which was deposited at bathyal depth (ca. $1000 \mathrm{~m}$ ) on the northern margin of the east-facing Canterbury Basin at a paleo-latitude of $c a .55^{\circ} \mathrm{S}$. LA-ICP-MS data yield trace element depth profiles through foraminifera test walls that can be used to identify and exclude zones of surficial contamination and infilling material resulting from diagenetic coatings, mineralisation and detrital sediment. Screened $\mathrm{Mg} / \mathrm{Ca}$ ratios from 5 species of foraminifera are used to calculate sea temperatures from late Early to early Middle Eocene (ca. 51 to $46.5 \mathrm{Ma}$ ), a time interval that spans the termination of the Early Eocene Climatic Optimum (EECO). During this time, sea surface temperatures (SST) varied from 30 to $24^{\circ} \mathrm{C}$, and bottom water temperatures (BWT) from 21 to $14^{\circ} \mathrm{C}$. Comparison of $\mathrm{Mg} / \mathrm{Ca}$ sea temperatures with published $\delta^{18} \mathrm{O}$ and $\mathrm{TEX}_{86}$ temperature data from the same samples (Hollis et al., 2009) shows close correspondence, indicating that LA-ICP-MS can provide reliable $\mathrm{Mg} / \mathrm{Ca}$ sea temperatures even where foraminiferal test preservation is variable. Agreement between the three proxies also implies that $\mathrm{Mg} / \mathrm{Ca}$ temperature calibrations for modern planktonic and benthic foraminifera can generally be applied to Eocene species, although some species (e.g., V. marshalli) show significant calibration differences. The $\mathrm{Mg} / \mathrm{Ca}$ ratio of the Eocene ocean is constrained by our data to be 35 $50 \%$ lower than the modern ocean depending on which $\mathrm{TEX}_{86}$ - temperature calibration (Kim et al., 2008; Liu et al., 2009) is used to compare with the $\mathrm{Mg} / \mathrm{Ca}$ sea temperatures.
\end{abstract}


Sea temperatures derived from $\delta^{18} \mathrm{O}$ analysis of foraminifera from Waipara show amplified variability relative to the $\mathrm{Mg} / \mathrm{Ca}$ and $\mathrm{TEX}_{86}$ proxies. This amplified variability is probably a diagenetic effect although it is possible that this Eocene $\delta^{18} \mathrm{O}$ record contains an ice volume component - the amplification signalling that temperature changes may have been accompanied by growth and collapse of ephemeral polar ice sheets on timescales of ca. $0.5 \mathrm{Myr}$.

Keywords: Early Eocene; greenhouse; $\mathrm{Mg} / \mathrm{Ca}$; sea temperature; paleoclimate, EECO, foraminifera; LA-ICP-MS

\section{Introduction}

Sea temperature estimates derived from magnesium/calcium $(\mathrm{Mg} / \mathrm{Ca})$ ratios, based on the thermodynamically controlled incorporation of $\mathrm{Mg}$ into the calcite tests of foraminifera, are widely used as a tool for reconstructing past climates (Mashiotta et al., 1999; Lear et al., 2000, 2008; Billups and Schrag, 2003; Tripati et al., 2003; Tripati and Elderfield, 2005; Burgess et al., 2008). Most previous applications of the $\mathrm{Mg} / \mathrm{Ca}$ thermometer have utilized bulk analytical methods where several foraminifer tests are crushed, chemically cleaned with oxidizing ( \pm reducing) agents, dissolved in acid and then analysed in solution. These methods require careful cleaning procedures to remove potential contaminant phases and detritus that may affect the measured test chemistry and could potentially result in erroneous paleo-sea temperatures. These methods also provide only a single temperature for each sample.

Advances in micro-analytical techniques, including laser ablation inductively coupled plasma mass spectrometry (LA-ICP-MS), now enable precise in situ analysis of trace elements in foraminifer tests at a spatial resolution of a few tens of microns. As the laser spot size is small relative to the size of foraminifer tests, this type of analysis permits multiple analyses to be made on a single specimen or even within a single test chamber. This can reveal both inter- and intra-individual trace element heterogeneity related to factors such as ecological or vital effects (Eggins et al., 2003, 2004; Reichart et al., 2003; Sadekov et al., 2008, 2009). One particularly useful feature of laser ablation analysis is that it yields a trace element depth profile through the foraminifer test wall that can be used to identify and exclude zones of surficial and internal contamination resulting from diagenetic coatings, mineralisation and presence of detrital sediment (Eggins et al., 2003). Thus, this method is particularly suited to the study of 
foraminifera from older sediments where the degree of preservation and effects of diagenesis may potentially compromise chemical and isotopic analyses of foraminifera by bulk analytical methods (e.g. Pearson et al., 2001).

In this study, we demonstrate how trace element data obtained by LA-ICP-MS can be utilised to estimate sea temperatures from Eocene foraminifera. These foraminifera were obtained from a river bank section through Ashley Mudstone at Mid-Waipara River, north Canterbury, South Island (Morgans et al., 2005). Ashley Mudstone is a calcareous mudstone that is inferred to have been deposited in upper bathyal depths at a paleo-latitude of $c a .55^{\circ} \mathrm{S}$. Biostratigraphic data indicate that the sampled interval represents continuous deposition from ca. 51 to $46.5 \mathrm{Ma}$ (Hollis et al. 2009). This time interval spans the termination of an interval of extreme global warmth that is referred to as the Early Eocene Climatic Optimum (EECO) and extends from ca. 53 to $50 \mathrm{Ma}$ (Zachos et al., 2001). The EECO was followed by a 17 Myr cooling trend, representing the transition from greenhouse to icehouse conditions. Oxygen isotope records indicate that ocean temperatures were much higher than today during the EECO (e.g. Shackleton and Boersma, 1981; Zachos et al., 2001). Coupled benthic $\mathrm{Mg} / \mathrm{Ca}-\delta^{18} \mathrm{O}$ studies suggest that variations in $\delta^{18} \mathrm{O}$ during the Early Eocene primarily reflect changes in temperature and that there was no significant continental ice (Lear et al., 2000; Billups and Schrag, 2003).

Hollis et al. (2009) presented geochemical and paleontological evidence for tropical sea surface temperatures in the Eocene at southern mid-latitudes from the same suite of 20 samples that are used in this study. However, those sea temperature estimates were primarily based on $\mathrm{TEX}_{86}$ (18 samples) and oxygen isotopes (13 samples), with $\mathrm{Mg} / \mathrm{Ca}$ data presented for only 5 samples of 3 species of foraminifera. Here we present a greatly expanded set of trace element data for up to 13 species of foraminifera taken from 19 of the Eocene samples. We compare our $\mathrm{Mg} / \mathrm{Ca}$ sea temperature estimates with the $\mathrm{TEX}_{86}$ and oxygen isotope data of Hollis et al. (2009). This comparison makes it possible to assess: (1) the potential of LA-ICP-MS to recover reliable trace element chemistry and sea temperatures from early Cenozoic foraminifera; (2) the validity of using $\mathrm{Mg} / \mathrm{Ca}$-temperature calibrations from modern foraminifera for extinct Eocene species; (3) the $\mathrm{Mg} / \mathrm{Ca}$ ratio of Eocene seawater. Our results also provide new insights into the transition from the Eocene greenhouse world 
to cooler climates and tentatively suggest that substantive ephemeral continental ice sheets may have developed periodically just after the EECO.

\section{Samples and Existing Comparative Data}

A Cretaceous-Cenozoic sedimentary succession outcrops along the banks and within the bed of the middle branch of the Waipara River (mid-Waipara) in north Canterbury. A $60 \mathrm{~m}$ section of Eocene Ashley Mudstone is exposed in the river bed a few hundred metres upstream from the lower gorge (New Zealand topographic 1:50,000 map series grid reference M34/783949 to 784947) (Column 6 in Morgans et al., 2005; see Chapter 1.5.1). The Ashley Mudstone ranges in age from Early to Middle Eocene (Waipawan to Bortonian local stages). It is inferred to conformably overlie the Paleocene Waipara Greensand and is unconformably overlain by the Karetu Sandstone (King et al., 1999). Early collections from this section (Jenkins, 1971) suggest that an intact Paleocene-Eocene boundary interval may lie directly downstream of the Ashley Mudstone exposure but it is currently buried under river scree. Neither the base nor top of the Ashley Mudstone is currently exposed in the section. A suite of 51 samples was collected in 2003 (Morgans et al. 2005) and subsets of these samples have been used to establish the age range of the section utilising calcareous nannofossil, foraminiferal, radiolarian and dinoflagellate cyst biostratigraphy (Hollis et al., 2009). The age model is based on age assignments for bioevents and New Zealand local stage boundaries given in Cooper (2004), which for the Paleogene is calibrated to Berggren et al. (1995). The Ashley Mudstone is inferred to have been deposited in a neritic watermass at upper bathyal depths of ca. $1000 \mathrm{~m}$ (Hollis et al., 2009). Palinspastic reconstructions of New Zealand during the Early Eocene place the New Zealand landmass between $c a .50^{\circ}$ to $60^{\circ}$ south (Hollis et al., 2009), approximately $10^{\circ}$ further south than the present day (Fig. 1). 


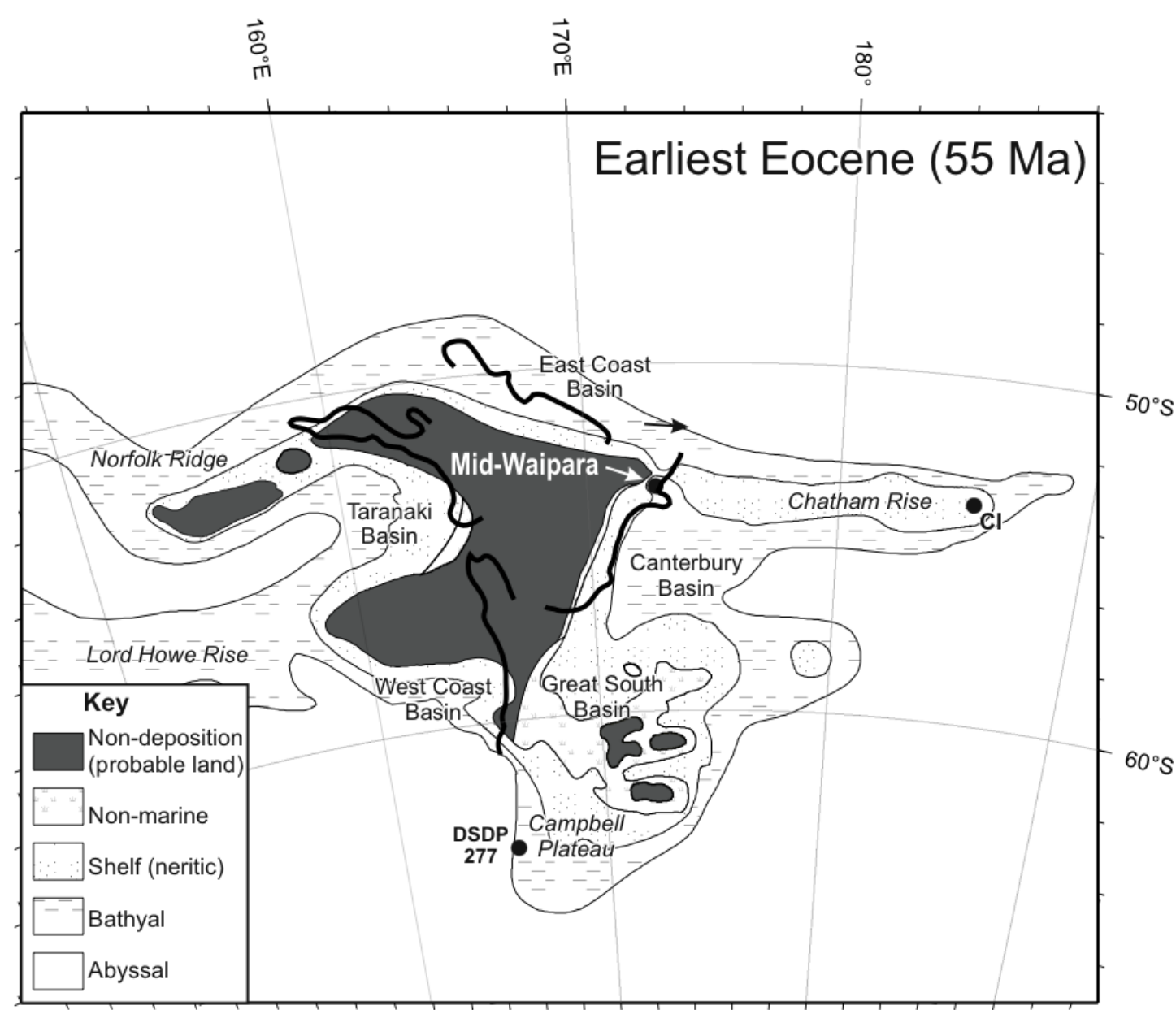

Figure 1. Paleogeographic map of New Zealand during the Early Eocene at ca. $55 \mathrm{Ma}$ (after Hollis et al., 2009). At this time, the New Zealand landmass was situated ca. $10^{\circ}$ further south than the present day and the mid-Waipara locality would have been at $c a$. $54^{\circ} \mathrm{S}$.

Foraminifera from a suite of 20 samples from the mid-Waipara section were prepared for geochemical analysis. In addition to the trace element data presented in this study, splits from the same samples have previously been analysed for oxygen and carbon isotopes (foraminifera) and $\mathrm{TEX}_{86}$ (archaeal membrane lipids) (Hollis et al., 2009). The degree of preservation of the foraminifera decreases markedly upward through the section, as documented by scanning electron microscope images (Fig. 2). A total of 13 species of foraminifera have been analysed in this study, comprising 5 planktonic species (Morozovella crater, M. lensiformis, Acarinina primitiva, A. collactea and Pseudohastigerina wilcoxensis) and 9 benthic species (Elphidium hampdenense, Anomalina visenda, Nuttallides carinotruempyi, Cibicides pre-parki, C. sp. A, C. collinsi, Vaginulinopsis marshalli, Bulimina subbortonica). 
Knowledge of the ecology of Eocene foraminifera is limited. Morozovellids are generally considered to be warm-water indicators and are common in (sub)tropical areas. A near-surface mixed layer habitat is indicated by oxygen and carbon isotopes (Boersma et al., 1987; Quilléveré et al., 2001; Berggren and Pearson, 2006). Acarinina collactea is a cosmopolitan species, ranging into latitudes $>50^{\circ}$ in both hemispheres, while Acarinina primitiva is essentially a temperate, high latitude species with an austral-subantarctic distribution (Berggren et al., 2006), and most acarininids are considered to be mixed-layer dwellers with carbon isotopes suggesting a photosymbiotic life habitat (Quilléveré et al., 2001; Berggren et al., 2006). Pseudohastigerina wilcoxensis is restricted to mid- to high latitudes. Studies of Pseudohastigerina taxa suggest a shallow water habitat (Poore and Matthews, 1984). Hayward et al. (1997) consider the benthic genus Elphidium to be mostly free-living, epifaunal, sometimes adopting a clinging lifestyle, and predominantly herbivorous (pinnate diatoms) although it sometimes can be detrivorous. However, given its occurrence in mainly bathyal sediments, E. hampdenense appears to have had quite a different habitat to most other species in the genus, which are restricted to shallow coastal waters. Bulimina is considered to be an infaunal taxon, and Vaginulinopsis (elongate nodosariid) is thought to have a similar habitat. Rotaline genera such as Cibicides and Nuttallides with flattened sides or with some sculpture may have some attaching epifaunal habitat either above or at the sediment-water interface. 


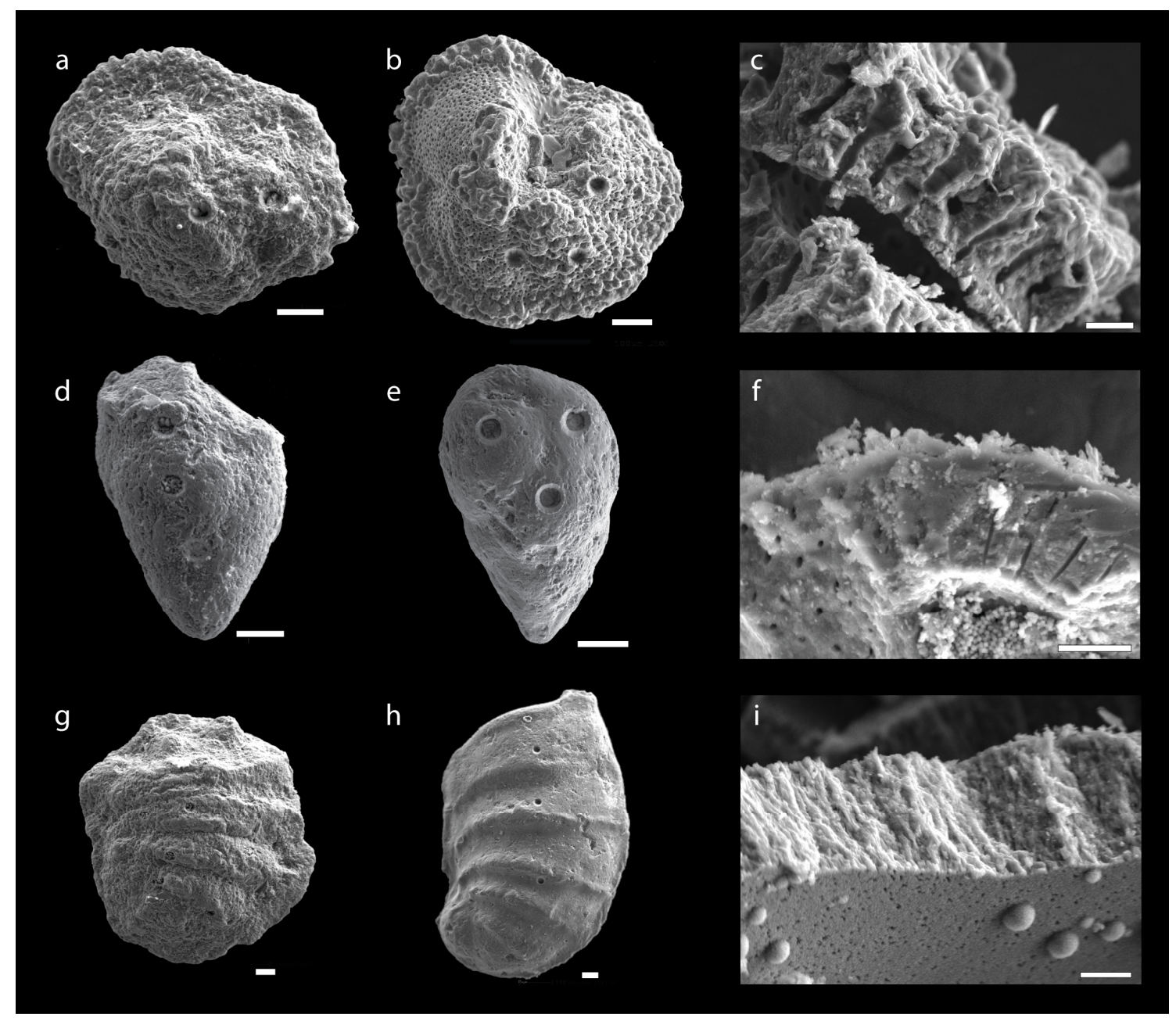

Figure 2. Scanning electron microscope images illustrating the variable preservation of mid-Waipara planktonic and benthic foraminifer tests. $(\mathrm{a}-\mathrm{c})=M$. crater; $(\mathrm{d}-\mathrm{f})=$ B. subbortonica; $(\mathrm{g}-\mathrm{i})=\mathrm{V}$. marshalli; (a), (d) and (g) are specimens from the upper part of the section where foraminifera are poorly preserved; (b), (e) and (h) are specimens from the lower part of the section where foraminifera are relatively well preserved; (c), (f) and (i) are images of cross-sections of test walls from relatively well preserved specimens. Diagenetic overgrowths are clearly visible in (c) and (f), showing that even the well preserved specimens have been diagenetically affected. The white scale bars on the whole specimens and wall cross sections are $50 \mu \mathrm{m}$ and $20 \mu \mathrm{m}$, respectively.

In the previous study of sea temperature variation in this section (Hollis et al., 2009), temperature estimates from $\delta^{18} \mathrm{O}$ were based on analyses of single specimens of foraminifera with the planktonic genus Morozovella used as an indicator of near-surface sea temperatures (SST) and the benthic genus Cibicides used as an indicator for seafloor bottom water temperatures (BWT), which is thought to represent intermediate water in this upper bathyal setting (Hollis et al., 2009). Temperatures were estimated using the equation of Erez and Luz (1983) assuming an ice-free $\delta^{18} \mathrm{O}_{\text {seawater value of - }}$ 
1\%o (Zachos et al., 1994). No corrections were made for surface-water salinity or other isotopic fractionation effects.

TEX $_{86}$ SST estimates (Hollis et al., 2009) were based on the relative distribution of glycerol dialkyl glycerol tetraether (GDGT) in membrane lipids from the marine picoplankton Crenarchaeota (Schouten et al., 2002, 2007), using the Kim et al. (2008) global calibration from core-top data that assumes a linear relationship between water temperature and $\mathrm{TEX}_{86}$ values. However, Liu et al. (2009) have argued that the exclusion of some core-top locations and outliers from the linear calibration narrows its geological application, and have produced a non-linear calibration from the same coretop sample set that fits all of the available data. Bijl et al. (2009) have subsequently argued that the exclusion of some data is appropriate due to the different behaviour of Crenarchaeota in some special settings and have continued to use the Kim et al. (2008) calibration. In this study, the $\mathrm{TEX}_{86}$ data from Hollis et al. (2009) have been converted into SSTs using both of these calibrations, and the differences between them are subsequently discussed.

A new TEX $_{86}$ calibration was recently published by Kim et al. (2010), which addresses the application of these calibrations to high sea-surface temperatures. The authors present two calibrations that represent fits to core-top $\mathrm{TEX}_{86}$ data from two groups of sites with different temperature ranges. The authors suggest that samples from a greenhouse world ocean, such as those from this study, be calibrated using their high temperature calibration, which was found to produce good agreement with $\delta^{18} \mathrm{O}$ data from planktonic foraminifera. Re-calculation of $\mathrm{TEX}_{86}$ temperatures using this calibration results in values that are intermediate between those calculated using the Kim et al. (2008) and Liu et al. (2009) calibrations - lower than the latter but higher than the former.

\section{Analytical Techniques}

\subsection{Sample preparation}

To recover foraminifera, samples of $c a .500 \mathrm{~g}$ of bulk sediment were dried at $<40^{\circ} \mathrm{C}$, and washed over a $75 \mu \mathrm{m}$ screen, dried again at $<40^{\circ} \mathrm{C}$, and the residue weighed and split for census data and faunal slides. Selected taxa were picked from faunal slides and prepared for LA-ICP-MS trace element analysis. Prior to analysis, all foraminifera 
tests were cleaned to remove adhering clay and other detrital material by repeated rinsing in ultra-pure (>18.2 $\mathrm{M} \Omega$ ) water and analytical reagent (AR) grade methanol. The cleaning procedure did not include an ultrasonication step as these Eocene specimens were found to easily disintegrate, and given the small number of specimens available, the risk of sample loss outweighed the potential benefit of removing small amounts of adhered/infilling material. Individual foraminifera were mounted onto double-sided tape attached to the surface of a wafer of National Institute of Standards and Technology glass standard NIST610 (Pearce et al., 1997; Jochum and Stoll, 2008).

\subsection{LA-ICP-MS trace element analysis}

Foraminifera were ablated with a New Wave $193 \mathrm{~nm}$ laser ablation system using a $25 \mu \mathrm{m}$ spot size and laser repetition rate of 2 or $3 \mathrm{~Hz}$ and laser power of $\sim 50 \%$. Under these conditions, a laser ablation pit is gradually ablated at a rate of $\sim 0.2$ to $0.3 \mu \mathrm{m} \mathrm{s}^{-1}$, yielding a trace element depth profile through the test. Ablation was carried out in a helium atmosphere and the ablated material carried to the ICP-MS torch in a heliumargon gas mixture. An Agilent 7500CS ICP-MS was used to measure trace element abundances relative to $\mathrm{Ca}$ during ablation. The isotopes ${ }^{24} \mathrm{Mg},{ }^{27} \mathrm{Al},{ }^{43} \mathrm{Ca},{ }^{55} \mathrm{Mn},{ }^{66} \mathrm{Zn}$, ${ }^{88} \mathrm{Sr}$ and ${ }^{138} \mathrm{Ba}$ were repeatedly scanned during ablation with dwell times of $10 \mathrm{~ms}$. Instrumental backgrounds of $60 \mathrm{~s}$ were determined prior to each analysis, which was typically $120 \mathrm{~s}$ long. Analyses of the NIST610 glass were interspersed between every 510 analyses of foraminifera to correct for trace element fractionation induced by the laser ablation and mass spectrometry procedures. Typical foraminifera (foram) and background (bg) rates $\quad$ (cps) $\quad$ were: $\quad{ }^{24} \mathrm{Mg}_{\text {foram }}=60000, \quad{ }^{24} \mathrm{Mg}_{\text {bg }}=300$; ${ }^{27} \mathrm{Al}_{\text {foram }}=160000,{ }^{27} \mathrm{Al}_{\mathrm{bg}}=5000 ;{ }^{43} \mathrm{Ca}_{\text {foram }}=42000,{ }^{43} \mathrm{Ca}_{\mathrm{bg}}=300 ;{ }^{55} \mathrm{Mn}_{\text {foram }}=14000$, ${ }^{55} \mathrm{Mn}_{\text {bg }}=5000 ; \quad{ }^{66} \mathrm{Zn}_{\text {foram }}=700, \quad{ }^{66} \mathrm{Zn}_{\mathrm{bg}}=40 ; \quad{ }^{88} \mathrm{Sr}_{\text {foram }}=85000, \quad{ }^{88} \mathrm{Sr}_{\mathrm{bg}}=20 ;$ ${ }^{138} \mathrm{Ba}_{\text {foram }}=8000,{ }^{138} \mathrm{Ba}_{\mathrm{bg}}=20$.

After LA-ICP-MS analysis, the foraminifera were carbon coated and imaged by scanning electron microscopy (SEM) to compare laser pits with their respective analyses to assess the preservation of foraminifer specimens and quality of each analysis. 


\subsection{Data reduction and screening}

Element/Ca ratios were plotted versus ablation time, producing a depth profile of foraminifera test chemistry from its exterior through to the interior (Fig. 3). Trace element profiles were then screened for the effects of diagenesis and contamination. Most trace element profiles show an enriched zone of high $\mathrm{Mg} / \mathrm{Ca}$ at the start of each analysis, followed by an interval of relatively constant and lower $\mathrm{Mg} / \mathrm{Ca}$, consistent with observations reported in previous in situ laser ablation studies of foraminifera (e.g. Eggins et al., 2003; Reichart et al., 2003; Pena et al., 2005; Sadekov et al., 2008). Ablating further into the interior of the foraminifera generally results in a return to high $\mathrm{Mg} / \mathrm{Ca}$ values, indicating that the laser has penetrated the inner wall of the test and is ablating infilling clay and/or secondary minerals. Zones of high $\mathrm{Mg} / \mathrm{Ca}$ are also typically marked by high $\mathrm{Al} / \mathrm{Ca}$ and $\mathrm{Mn} / \mathrm{Ca}$. For the purposes of calculating $\mathrm{Mg} / \mathrm{Ca}$ sea temperatures, the enriched outer and inner zones are excluded from the mean and just the interval of constant and low $\mathrm{Mg} / \mathrm{Ca}$, representing the primary foraminiferal calcite, is averaged (Fig. 3). Depth profiles were found to vary significantly between species due to varying properties (thickness, density etc.) of tests from different taxa. Benthic species generally yield better laser ablation profiles as a result of ablation of their denser, less porous, less ornamented, and flatter tests. Some species (particularly $V$. marshalli) consistently produced long, regular depth profiles, of which the integrated segment comprised most of the analysis (Fig. 3a). 

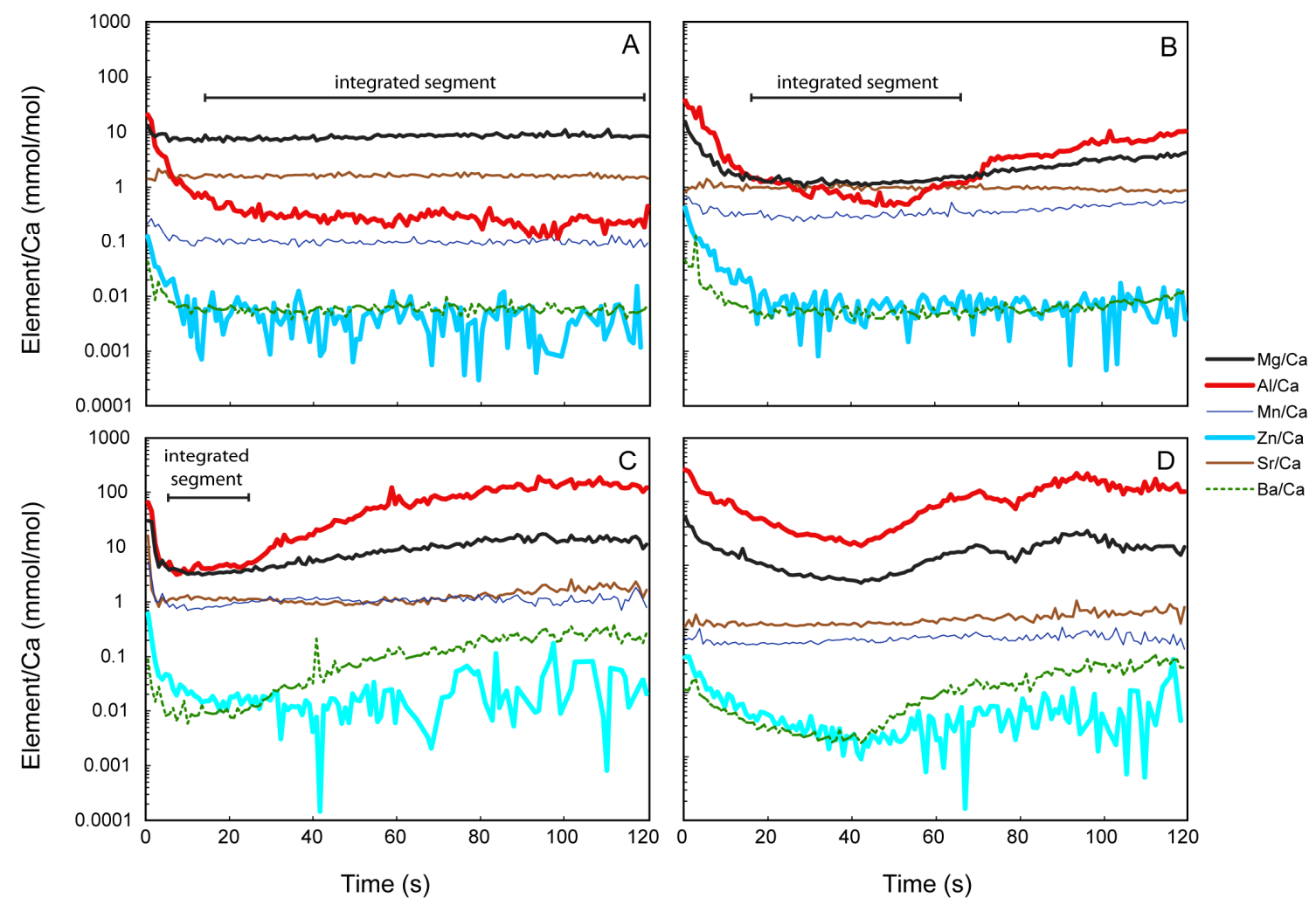

Figure 3. Examples of LA-ICP-MS trace element depth profiles showing the different types of profiles through foraminifera test walls and how these are screened to yield reliable $\mathrm{Mg} / \mathrm{Ca}$ data. The lower scale on the profiles is ablation time, which corresponds to a depth of ca. 0.2-0.3 $\mu \mathrm{m} \mathrm{s}^{-1}$. In profiles (A - C) a surface veneer that is enriched in trace elements is clearly visible. This is followed by an interval of variable thickness characterized by low and relatively constant $\mathrm{Mg} / \mathrm{Ca}$, which is interpreted to be the part of the profile reflecting primary foraminiferal calcite chemistry that is averaged for the calculation of $\mathrm{Mg} / \mathrm{Ca}$ sea temperatures. The deeper part of most profiles typically shows a return to higher trace element/Ca values that may indicate that the laser is ablating material infilling chambers or secondary minerals. (A) an example of a 'good' profile where the segment that can be used for temperature determination comprises most of the analysis, which was typical of the benthic species $V$. marshalli, but was less common for other taxa; (B) a 'fair' profile where the usable segment is perhaps half of the analysis, which was common amongst most species analysed in this study; (C) a 'short' profile typical of the more delicate benthic species such as $B$. subbortonica where only a limited part of the profile represents the primary trace element signal of the foraminiferal calcite; (D) an example of a 'bad' profile that would not be used in this study, as was in the case for a significant number of analyses of planktonic taxa, particularly towards the top of the mid-Waipara section.

After screening of depth profiles, summary trace element data was scrutinized, and analyses with anomalously high values in any trace element were also discarded. Unscreened data also shows a linear correlation between $\mathrm{Mg} / \mathrm{Ca}$ and $\mathrm{Al} / \mathrm{Ca}$, which reflects the influence of silicate contamination (interpreted as small amounts of sediment infilling pores). Following Barker et al. (2003), the composition of the contaminant can be approximately determined by plotting $\mathrm{Mg} / \mathrm{Ca}$ versus $\mathrm{Al} / \mathrm{Ca}$, from 
which the slope of a linear regression gives the $\mathrm{Al} / \mathrm{Mg}$ ratio of the sediment. Once the contaminant composition is known, screening limits for silicate contamination can be set by calculating the $\mathrm{Al} / \mathrm{Ca}$ ratio at which $\mathrm{Mg} / \mathrm{Ca}$ would be biased sufficient to alter temperatures by $>1{ }^{\circ} \mathrm{C}$. The sediment composition from the mid-Waipara samples was determined from a plot of all unscreened data from all species, excluding only analyses with extreme values of $\mathrm{Al} / \mathrm{Ca}(>50 \mathrm{mmol} / \mathrm{mol})$. This yielded an $\mathrm{Al} / \mathrm{Mg}$ ratio of 8.1 (i.e. much less Mg-rich than the sediment in Barker et al. (2003)) from which screening limits were calculated for each species. The screening limit also depends on the calibration used (i.e. planktonic or benthic) and the typical $\mathrm{Mg} / \mathrm{Ca}$ ratio for each species. For example, the planktonic species $M$. crater has a typical $\mathrm{Mg} / \mathrm{Ca}$ value of ca. 3.6 $\mathrm{mmol} / \mathrm{mol}$. Based on the planktonic calibration, an increase of $9 \%(0.325 \mathrm{mmol} / \mathrm{mol})$ $\mathrm{Mg} / \mathrm{Ca}$ would increase the calculated temperature by $1^{\circ} \mathrm{C}$. Based on the equation of Barker et al. (2003; $\left.\mathrm{Mg} / \mathrm{Ca}_{\text {(excess) }}=\mathrm{Al} / \mathrm{Ca}_{\text {(sample) }} / \mathrm{Al} / \mathrm{Mg}_{\text {(contaminant) }}\right)$, the required limit for $\mathrm{Al} / \mathrm{Ca}$ in this case is $0.325 \times 8.1=2.6 \mathrm{mmol} / \mathrm{mol}$. Thus, when the data are screened in this way, no analysis should overestimate temperature by more than $1^{\circ} \mathrm{C}$. For the detailed temperature-time records presented in section 4.1, each species was screened with individual $\mathrm{Al} / \mathrm{Ca}$ limits (mmol/mol) of 2.6 for M. crater, 2.3 for A. primitiva, 3.5 for Cibicides sp. A, 2.5 for B. subbortonica, and 7.2 for V. marshalli (see Chapter 2.3.2).

\subsection{Calculating Mg/Ca paleotemperatures}

$\mathrm{The} \mathrm{Mg} / \mathrm{Ca}$ ratio is related to water temperature by the equation:

$$
\mathrm{Mg} / \mathrm{Ca}=\left(\mathrm{Mg} / \mathrm{Ca}_{\text {sw-t }} / \mathrm{Mg} / \mathrm{Ca}_{\text {sw- } 0}\right) \times \mathrm{A} \times \mathrm{e}^{(\mathrm{B} \times \mathrm{T})}
$$

$\mathrm{Mg} / \mathrm{Ca} \mathrm{s}_{\mathrm{sw}}$ is seawater $\mathrm{Mg} / \mathrm{Ca}$ at time $\mathrm{t}$ (i.e., Eocene, subscript $\mathrm{t}$ ) and today (subscript $0), A$ and $B$ are the pre-exponential and exponential constants respectively, and $T$ is temperature (Lear et al., 2002). The temperatures from Eocene foraminifera were calculated using a multi-species $\mathrm{Mg} / \mathrm{Ca}$-temperature calibration for modern tropical and sub-tropical planktonic foraminifera $(A=0.38, B=0.09$; Anand et al., 2003), and a calibration from three modern Cibicidoides species for benthic foraminifera $(A=0.867$, $B=0.109$; Lear et al., 2002). Based on the uncertainties in these published calibrations, the propagated error in reconstructed temperatures is ca. $\pm 1.5^{\circ} \mathrm{C}$ for both planktonic and benthic species. 
Secular changes in the $\mathrm{Mg} / \mathrm{Ca}$ ratio of seawater $\left(\mathrm{Mg} / \mathrm{Ca}_{\mathrm{sw}}\right)$ have occurred over timescales of millions of years, and various models and proxies have estimated $\mathrm{Mg} / \mathrm{Ca}_{\mathrm{sw}}$ through time (Hardie, 1996; Stanley and Hardie, 1998; Wilkinson and Algeo, 1989; Zimmermann, 2000; Lowenstein et al., 2001, 2003; Lear et al., 2002; Dickson, 2002; Billups and Schrag, 2003; Coggon et al., 2010). Given that Eocene seawater is likely to have had lower $\mathrm{Mg} / \mathrm{Ca}$ than the present day, we calculated sea temperatures using a conservative estimate of Eocene seawater $\mathrm{Mg} / \mathrm{Ca}$ of $3.35 \mathrm{mmol} / \mathrm{mol}$, or $35 \%$ lower than the present day (Lear et al., 2002), although other estimates do predict lower values. An even lower $\mathrm{Mg} / \mathrm{Ca}$ ratio for Eocene seawater has the effect of increasing calculated $\mathrm{Mg} / \mathrm{Ca}$ sea temperatures, and thus we consider all our presented temperature estimates are minimum values.

\section{Results}

\subsection{Comparative analyses of 13 species from three samples of the mid-Waipara section}

A preliminary study of the Eocene foraminifera found at mid-Waipara involved the characterization of the different species to select a set for use in the detailed temperature-time record. Three samples (MW106, MW112, and MW118) with the widest assemblage of species were selected, and every species present was analysed. From these three samples a total of 13 different species have been analysed, with typically 5 individuals of each species per sample (Table 1). At least 3 analyses were made of each individual foraminifer test, although a number of specimens were analysed up to 10 times to estimate the degree of intra-test variability in well preserved specimens. Mean element/Ca ratios from screened analyses from these three samples are presented in Table 3.

Trace element depth profiles were found to vary considerably between species (Fig. 3), and the relative quality of profiles from each species is apparent in the standard errors (\% $2 \mathrm{se}$ ) on $\mathrm{Mg} / \mathrm{Ca}$ (Table 1$)$. Analyses where only a relatively short portion of the profile could be used had relatively large standard errors (e.g. G. wilcoxensis, typical $\% 2$ se ca. 5\%), whereas some benthic species consistently produced long, regular trace element/Ca depth profiles of which the segment used to calculate $\mathrm{Mg} / \mathrm{Ca}$ sea temperatures comprised most of the analysis (e.g. V. marshalli, typical \% 2 se ca. $1-2 \%$ ). For some species, very few analyses passed the depth profile and $\mathrm{Al} / \mathrm{Ca}$ 
screening process, whereas for others the most analyses passed the screening process (Table 3). For example, $>80 \%$ of analyses of $V$. marshalli from these three samples passed the screening process, whereas for planktonic species $>50 \%$ of analyses were screened (i.e. rejected). Intra- and/or inter-test variability also varied between species: reconstructed $\mathrm{Mg} / \mathrm{Ca}$ sea temperatures from some species show a large range, while other species produce very consistent temperatures. The variability in each species is apparent in the standard deviation $(2 \sigma)$ of the temperatures that went into the sample means (Table 1). Temperatures calculated from $\mathrm{Mg} / \mathrm{Ca}$ ratios of planktonic taxa were generally more variable, possibly reflecting their mobility in the water column, and the fact that sea surface temperatures are more variable than sea floor temperatures. Confidence intervals $(95 \% \mathrm{CI})$ were calculated from the data that were used in calculating the sample means, and reflects both the variability in the data $(2 \sigma)$ and the number of analyses that went into the sample mean (t-distribution, TINV). In these three samples, confidence intervals on both planktonic and benthic temperatures are $c a . \pm 2$ $3^{\circ} \mathrm{C}$.

In all three samples, the surface-dwelling planktonic species $M$. crater has $\mathrm{Mg} / \mathrm{Ca}$ $=3.0$ to $3.5 \mathrm{mmol} / \mathrm{mol}$, corresponding to sea surface temperatures of $\sim 28-30^{\circ} \mathrm{C} . \mathrm{Mg} / \mathrm{Ca}$ temperatures calculated for $M$. lensiformis were generally slightly cooler than but very similar to those of $M$. crater. A. primitiva gives $\mathrm{Mg} / \mathrm{Ca}$ sea surface temperatures $c a .0 .7$ $2.6^{\circ} \mathrm{C}$ cooler than $M$. crater, and calculated temperatures for A. collactea from all three samples were $1.5-1.9^{\circ} \mathrm{C}$ warmer than $M$. crater, indicating a subtle difference in the $\mathrm{Mg} / \mathrm{Ca}$ - temperature calibration between the Morozovellids and Acarininids. In general, however, the multi-species planktonic $\mathrm{Mg} / \mathrm{Ca}$ - temperature calibration appears to produce consistent temperatures for all the studied planktonic species.

With the exception of two benthic species, temperatures calculated from benthic foraminifera $\mathrm{Mg} / \mathrm{Ca}$ data $(2.6$ to $6.1 \mathrm{mmol} / \mathrm{mol}$ ) from these three samples fall within a relatively narrow range of $14-22^{\circ} \mathrm{C}$. However, two species in particular exhibit large systematic differences in calculated $\mathrm{Mg} / \mathrm{Ca}$ bottom water temperatures as compared to the other benthic species. The species $V$. marshalli has systematically high $\mathrm{Mg} / \mathrm{Ca}$ ratios of $c a .8 \mathrm{mmol} / \mathrm{mol}$, giving rise to $\mathrm{Mg} / \mathrm{Ca}$ temperatures $c a .5^{\circ} \mathrm{C}$ warmer than the other benthic species. Conversely, $N$. carinotruempyi has very low $\mathrm{Mg} / \mathrm{Ca}$ values of $c a .1$ $\mathrm{mmol} / \mathrm{mol}$, yielding calculated $\mathrm{Mg} / \mathrm{Ca}$ temperatures that are in general $c a .9^{\circ} \mathrm{C}$ cooler temperatures than the other benthic species. Since the temperatures were all calculated 
using the same $\mathrm{Mg} / \mathrm{Ca}$-temperature calibration, and the temperatures for these benthic species should be approximately the same, these systematic offsets suggest that the $\mathrm{Mg} / \mathrm{Ca}$-temperature relationships for the species V. marshalli and $N$. carinotruempyi are the least well described by the average benthic calibration used. The other benthic species showed much smaller offsets in their $\mathrm{Mg} / \mathrm{Ca}$-temperature calibrations, and offsets were arbitrarily normalized by adjusting all benthic species by the mean difference from C. sp. A in these three samples, as it is the most closely related to the modern species for which the $\mathrm{Mg} / \mathrm{Ca}$-temperature calibration was established (Lear et al., 2002). With this cross-calibration applied the range in benthic temperatures from these 3 samples is reduced to $c a .3 .5^{\circ} \mathrm{C}$.

On the basis of the data obtained in this preliminary investigation, 5 species were selected (M. crater, A. primitiva, C. sp. A, B. subbortonica, and V. marshalli) for analysis through the entire suite of mid-Waipara samples. In general these 5 species were characterized by the least disturbed trace element profiles and most consistent data (Table 1; Fig. 3).

Table 1. Trace element data for up to 13 species from three mid-Waipara samples MW106, MW112 and MW118 - used in a preliminary study to establish the most reliable species to analyse in this study. Element/Ca ratios are averages from analyses that passed screening procedures described in the text. All $\mathrm{Mg} / \mathrm{Ca}$ temperatures for benthic taxa presented later in this paper were arbitrarily normalized by adjusting all benthic species by the mean difference from $C$. sp. A in these three samples. 2 x standard error in $\mathrm{Mg} / \mathrm{Ca}$ data, expressed as a percentage, which largely reflects the length of the segment of the profiles used for temperature calculation i.e., lower $\% 2$ se values indicate longer profiles through primary foraminiferal calcite. " 2 standard deviations in temperature data that passed screening. ${ }^{* *} 95 \%$ confidence intervals calculated for each sample based the mean temperature and the number of analyses that passed the screening process. "good" analyses refers to those that passed the screening process and were utilized in calculating the sample means. 


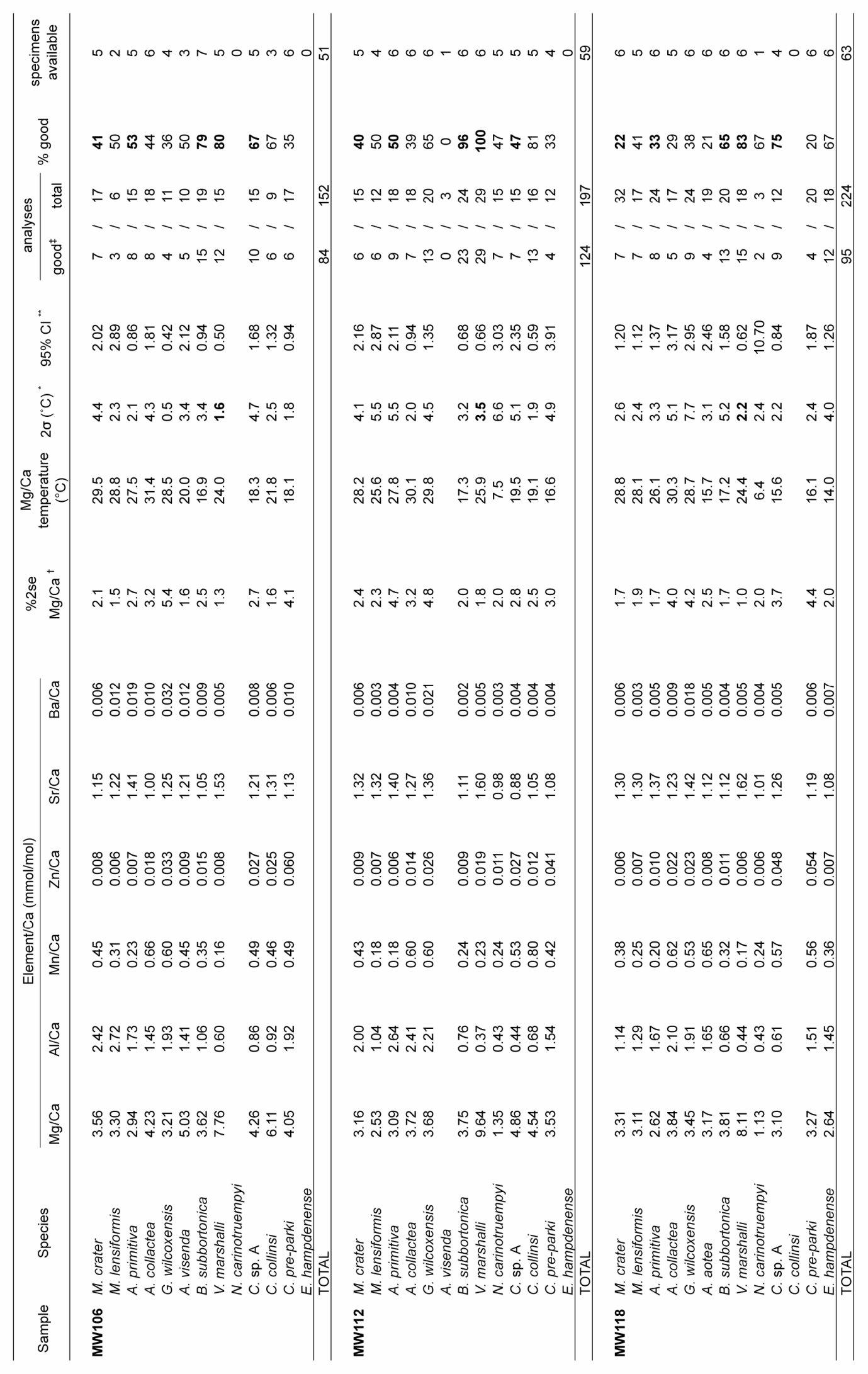




\subsection{Trace element/Ca analysis of 5 species from throughout the mid-Waipara section}

The five selected species analysed from all of the mid-Waipara samples, cover the period 50.7 to $46.5 \mathrm{Ma}$ at a temporal resolution of 100 to $300 \mathrm{kyr}$ (Table 2). Both the abundance of foraminifera and their degree of preservation decrease upward through the section. Planktonic species were generally found to yield poorer analyses than benthics with only ca. $30 \%$ of the total analyses for each of the planktonic species passing the screening process, compared with $c a$. $70 \%$ for the benthic species. The decrease in preservation towards the top of the section is often reflected by extreme trace element/Ca ratios, which has resulted in more analyses being rejected, and many of the samples from the upper part of the section yield few, if any, useable analyses from planktonic species. The preservation has had a lesser effect on the quality of the benthic trace element data, even at the top of the section where only the most diagenetically affected samples had $<50 \%$ of the analyses passing screening.

Table 2. Trace element/Ca ratios for the 5 selected species analysed throughout the midWaipara section showing variations in trace element chemistry over the period ca. 51 46.5 Ma. Trace element ratios that are presented are averages of data that passed screening procedures. The decrease in preservation up the section, also seen in the reduced number of specimens available, is accompanied by relative extremes in trace element data that have resulted in a greater number of analyses being discarded. Confidence intervals for benthic species are much smaller than those of planktonic species. ${ }^{\dagger} 2 \mathrm{x}$ standard error in $\mathrm{Mg} / \mathrm{Ca}$ data, expressed as a percentage, which largely reflects the length of the segment of the profiles used for temperature calculation i.e., lower \% 2 se values indicate longer profiles through primary foraminiferal calcite. ${ }^{\dagger}$ Benthic temperatures are adjusted as described in the text. " 2 standard deviations in temperature data that passed screening. ${ }^{* *} 95 \%$ confidence intervals calculated for each sample based the mean temperature and the number of analyses that passed the screening process. " "good" analyses refers to those that passed the screening process and contributed to the sample means. 


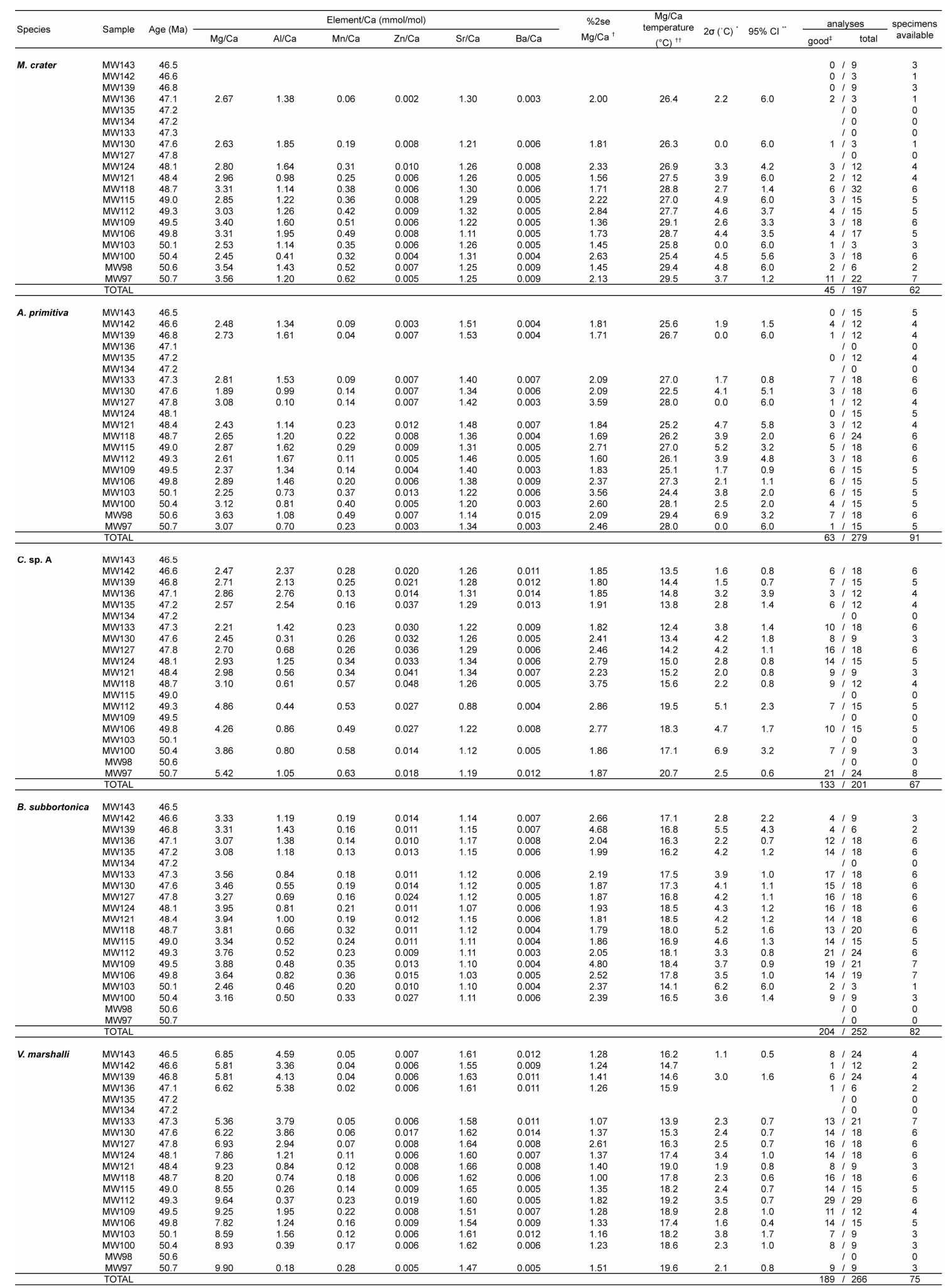


$\mathrm{Al} / \mathrm{Ca}$ ratios were generally observed to increase up-section in all species, accompanying the decrease in preservation. However, the screening process effectively removes any effect on calculated $\mathrm{Mg} / \mathrm{Ca}$ paleo-sea temperatures as no significant correlation between $\mathrm{Al} / \mathrm{Ca}$ and $\mathrm{Mg} / \mathrm{Ca}$ amongst the individual analyses of any species from a particular sample is observed. $\mathrm{Sr} / \mathrm{Ca}$ ratios are essentially uniform throughout the record within each species, although there appear to be subtle systematic differences in $\mathrm{Sr} / \mathrm{Ca}$ ratios between different species. For example, while most of the species have average $\mathrm{Sr} / \mathrm{Ca}=1.1$ to $1.3 \mathrm{mmol} / \mathrm{mol}, V$. marshalli exhibits higher $\mathrm{Sr} / \mathrm{Ca}$ of ca. $1.6 \mathrm{mmol} / \mathrm{mol}$, which accompanies its systematically higher $\mathrm{Mg} / \mathrm{Ca}$ as compared to the other benthic species. All species show a marked decrease (60-90\%) in $\mathrm{Mn} / \mathrm{Ca}$ towards the top of the section. While most trace element depth profiles (e.g., Fig. 3) show a $\mathrm{Mn} / \mathrm{Ca}$ enrichment at the surface, in most analyses for the remainder of the depth profile, $\mathrm{Mn} / \mathrm{Ca}$ is relatively constant and $\mathrm{Mn} / \mathrm{Ca}$ ratios are also consistent between individuals within each sample.

For most samples, $\mathrm{Mg} / \mathrm{Ca}$ temperatures from the three benthic species (C. sp. A, $B$. subbortonica and V. marshalli) are within ca. $2.5^{\circ} \mathrm{C}$ of each other, although for several samples they differ by up to $c a .4^{\circ} \mathrm{C}$. The disparity between the three benthic temperature series is greatest at the top of the section where the data is poorest. However, these temperatures are still mostly within error of one another. The $95 \%$ confidence intervals (based on intra-sample variability) in the benthic $\mathrm{Mg} / \mathrm{Ca}$ temperature data are typically on the order of $0.5-1.5^{\circ} \mathrm{C}$, although these are significantly higher for samples that had very few analyses.

\subsection{Changes in $\mathrm{Mg} /$ Ca paleotemperatures through the mid-Waipara section}

Smoothed records for SST and BWT were calculated from weighted means of the $\mathrm{Mg} / \mathrm{Ca}$ temperatures from planktonic and benthic foraminifera taxa, respectively. Weightings are based on 95\% confidence intervals (CI) for each temperature data point (i.e. intra-sample variability). Temperatures that are based on a single analysis (i.e. have no standard deviation) were given a low, but not zero, weighting. Data points that end up with artificially large confidence intervals solely from the small number of analyses, (i.e. have a similar standard deviation but a large t-distribution (TINV)) were given fixed confidence intervals of $6^{\circ} \mathrm{C}$. The smoothed records are found to describe the data 
set well (Fig. 4, Table 3). Most of the residual temperatures for the planktonic data include zero in their error bars, and the same is true for almost all of the benthic residual temperatures.

Planktonic foraminiferal $\mathrm{Mg} / \mathrm{Ca}$ ratios range from $c a .3 .6 \mathrm{mmol} / \mathrm{mol}$ at the bottom of the section to $c a .2 .0 \mathrm{mmol} / \mathrm{mol}$ at the top of the section, indicating a general cooling from $\mathrm{ca} .30^{\circ} \mathrm{C}$ to $23^{\circ} \mathrm{C}$. Temperatures are relatively stable for the first half of the record yielding $27-30^{\circ} \mathrm{C}$ from planktonic species and $18-21^{\circ} \mathrm{C}$ from benthic species, with the exception of two samples (MW100 and MW103), which are cooler by $c a .4^{\circ} \mathrm{C}$ for planktonic species and $2-3^{\circ} \mathrm{C}$ for benthic species. In sample MW115 (49.0 Ma), $M$. crater yields a slightly cooler temperature that may represent a subtle cooling that is not observed in the benthic record. The second half of the record is dominated by a cooling trend from ca. 48.7 Ma, observed in both SST and BWT.

In general, the $\mathrm{Mg} / \mathrm{Ca} \mathrm{SST}$ and BWT records show strong agreement. An overall trend of cooling is observed in both the SST and BWT records. Temperatures during the first half of the record (ca. $51-48.7 \mathrm{Ma}$ ) were relatively stable, with most of the observed cooling taking place from $c a$. 48.7 Ma onwards. A transient cooling event is observed in SST and BWT between ca. 50.5 and $50.0 \mathrm{Ma}$, with a ca. $4^{\circ} \mathrm{C}$ decrease in SST, and a slightly subdued cooling of $2-3^{\circ} \mathrm{C}$ in the BWT record. However, the broad cooling over the entire record is approximately equal in magnitude $\left(\mathrm{ca} .5-6^{\circ} \mathrm{C}\right)$ in both the SST and BWT records. 


\section{Discussion}

\subsection{Do the Mg/Ca temperatures reliably record past sea temperatures?}

The three different temperature proxy records $\left(\mathrm{Mg} / \mathrm{Ca}, \mathrm{TEX}_{86}, \delta^{18} \mathrm{O}\right)$ available from mid-Waipara all yield very warm temperatures for the Early Eocene and a general cooling trend over the length of the record (Fig. 4). The three SST proxies yield similar temperatures in the range $25-35^{\circ} \mathrm{C}$, and the two benthic records are in the range 15 $25^{\circ} \mathrm{C}$. The proxy records show common temporal variations, but these vary in magnitude between different proxies. While there is good agreement between the $\mathrm{Mg} / \mathrm{Ca}$ and $\mathrm{TEX}_{86}$ SSTs, which is discussed further in Section 5.2, the oxygen isotope records are slightly more complicated. The planktonic $\delta^{18} \mathrm{O}$ temperature record has roughly the same mean value as the planktonic $\mathrm{Mg} / \mathrm{Ca}$ and $\mathrm{TEX}_{86}$ temperature records and shows very similar trends. However, the $\delta^{18} \mathrm{O}$ SST changes are significantly larger than those recorded by $\mathrm{Mg} / \mathrm{Ca}$ ratios or $\mathrm{TEX}_{86}$ data (Fig. 4). The benthic $\delta^{18} \mathrm{O}$ record also records these amplified changes in temperatures as compared to the other proxies. The reasons for this are considered further in Section 5.3.

Figure 4. Paleo-sea temperature data from the mid-Waipara section. A) $\mathrm{Mg} / \mathrm{Ca}$ temperatures from mid-Waipara for 5 species of foraminifera. Blue circles $=M$. crater; orange circles $=A$. primitiva; red circles $=C$. sp. A; purple circles $=B$. subbortonica; green circles $=V$. marshalli. Error bars on the data are $95 \%$ confidence intervals based on the range of temperatures that were used to calculate the average temperature from each species for each sample. Solid lines are smoothed SST (red) and BWT (blue) records, which are weighted means of the $\mathrm{Mg} / \mathrm{Ca}$ data at each point from $95 \%$ confidence intervals. The $M$. crater $\mathrm{Mg} / \mathrm{Ca}$ record shows much better agreement with other SST proxies than the smoothed SST from $M$. crater and A. primitiva, thus the $M$. crater records (dashed blue line) is our preferred $\mathrm{Mg} / \mathrm{Ca}$ SST record. B) TEX86 sea surface temperature data from Hollis et al. (2009) calculated using two different calibrations. The dark green line is the non-linear calibration of Liu et al. (2009), whereas the light green line is the linear calibration of Kim et al. (2008). C) Oxygen isotope data and calculated calcification temperatures. Red lines are the temperature record from planktonic foraminifera (Morozovella) and blue lines are the temperature record from benthic foraminifera (Cibicides). Solid lines are calculated with a fixed $\delta^{18} O_{\text {sw }}$ of $-1 \%$ (Zachos et al., 1994). Dashed lines are calculated using the $\delta^{18} \mathrm{O}_{\text {sw }}$ in (d). D) $\delta^{18} \mathrm{O}_{\text {sw }}$ back-calculated from benthic foraminiferal $\delta^{18} \mathrm{O}$ and $\mathrm{Mg} / \mathrm{Ca}$ temperatures, as described in the text and Supplementary Information. Conversion to sea-level equivalent of ice volume utilises the Pekar and DeConto (2006) calibration of $0.35 \%$ per $10 \mathrm{~m}$. 

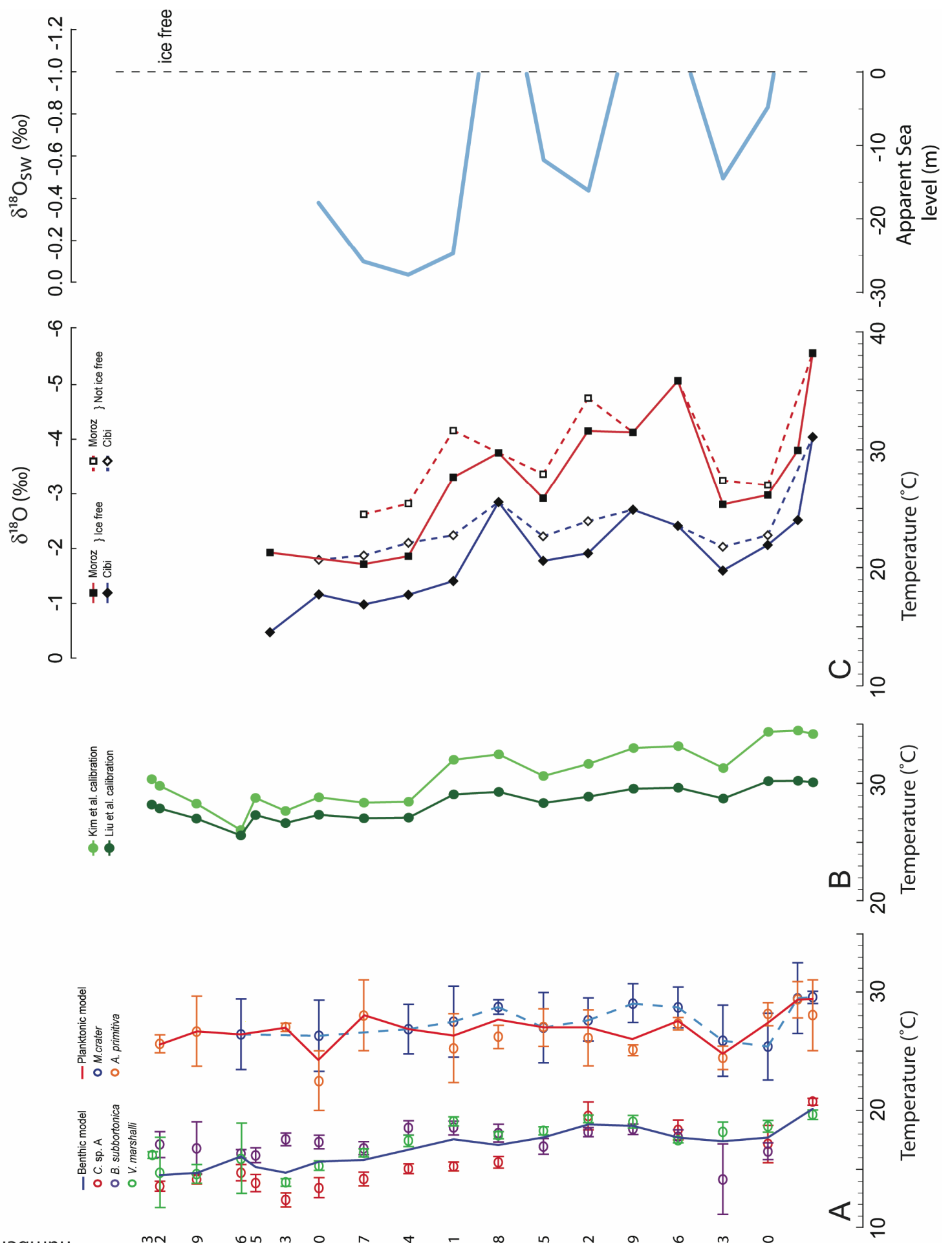

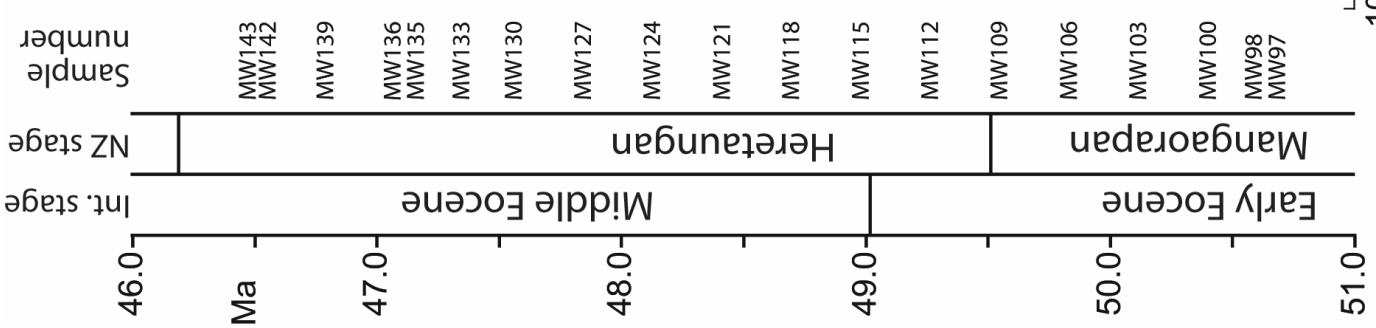


Figure 5 shows several of the various proxy records normalized to their standard deviations (i.e. mean subtracted and variability scaled to number of standard deviations from the mean). These normalized records give a clear picture of the temperature trends over time, and illustrate that the temperature variability is very consistent between the proxy records. Of the two planktonic $\mathrm{Mg} / \mathrm{Ca}$ records, $M$. crater shows a much better agreement with the other records than the smoothed SST record $(M$. crater $+A$. primitiva), and the $M$. crater $\mathrm{Mg} / \mathrm{Ca}$ record is the preferred $\mathrm{Mg} / \mathrm{Ca}$ SST record obtained in this study. The correlation between these records gives clear evidence that the three independent proxies are all recording a common (temperature) signal.

As a means of quantifying how well the different proxies agree, the smoothed benthic $\mathrm{Mg} / \mathrm{Ca}$-temperature record was treated as a 'model' temperature. Residual (proxy - model) temperatures were calculated for each of the other proxies after correcting for mean offsets. For example, if the $\mathrm{TEX}_{86}$ temperature record (using the Liu et al. calibration) had the same mean as the smoothed benthic record, the average difference (= mean residual) between the two records would be just $0.8^{\circ} \mathrm{C}$. Using the Kim et al. (2008) calibration the mean residual would be $1.3^{\circ} \mathrm{C}$. Thus, $\mathrm{TEX}_{86}$ temperatures from both calibrations show a strong agreement with $\mathrm{Mg} / \mathrm{Ca}$ temperatures. The oxygen isotope temperature residuals are much larger, as expected given the much larger amplitudes of the variations in the data, with mean residuals of $3.7^{\circ} \mathrm{C}$ for the planktonic $\delta^{18} \mathrm{O}$ temperatures, and $2.5^{\circ} \mathrm{C}$ for the benthic $\delta^{18} \mathrm{O}$ temperatures.

Figure 5. Mid-Waipara proxy data showing the agreement between the different temperature records available for this locality in the Eocene. The agreement between the various records is readily apparent when temperatures are normalized to their standard deviations, i.e. each point is represented as the number of standard deviations from the mean temperature of that record. (A) and (B) are the benthic $\delta^{18} \mathrm{O}$ and $\mathrm{Mg} / \mathrm{Ca} \mathrm{BWT}$ records and $(\mathrm{C})$ and $(\mathrm{D})$ are the planktonic $\delta^{18} \mathrm{O}$ and $\mathrm{Mg} / \mathrm{Ca} \mathrm{SST}$ records, respectively, and (E) is the TEX $_{86}$ SST record. The normalized records display the relative temperature trends and the similarity between all the records irrespective of the type of proxy used to track sea temperatures. The excellent agreement between these independent records gives confidence that the LA-ICP-MS technique can extract reliable sea temperatures in foraminifera from these samples. Three periods are shaded showing periods of relative cooling, in particular the period from ca. 48.7 Ma onwards which represents the termination of the EECO and the beginning of the transition to the icehouse world. 

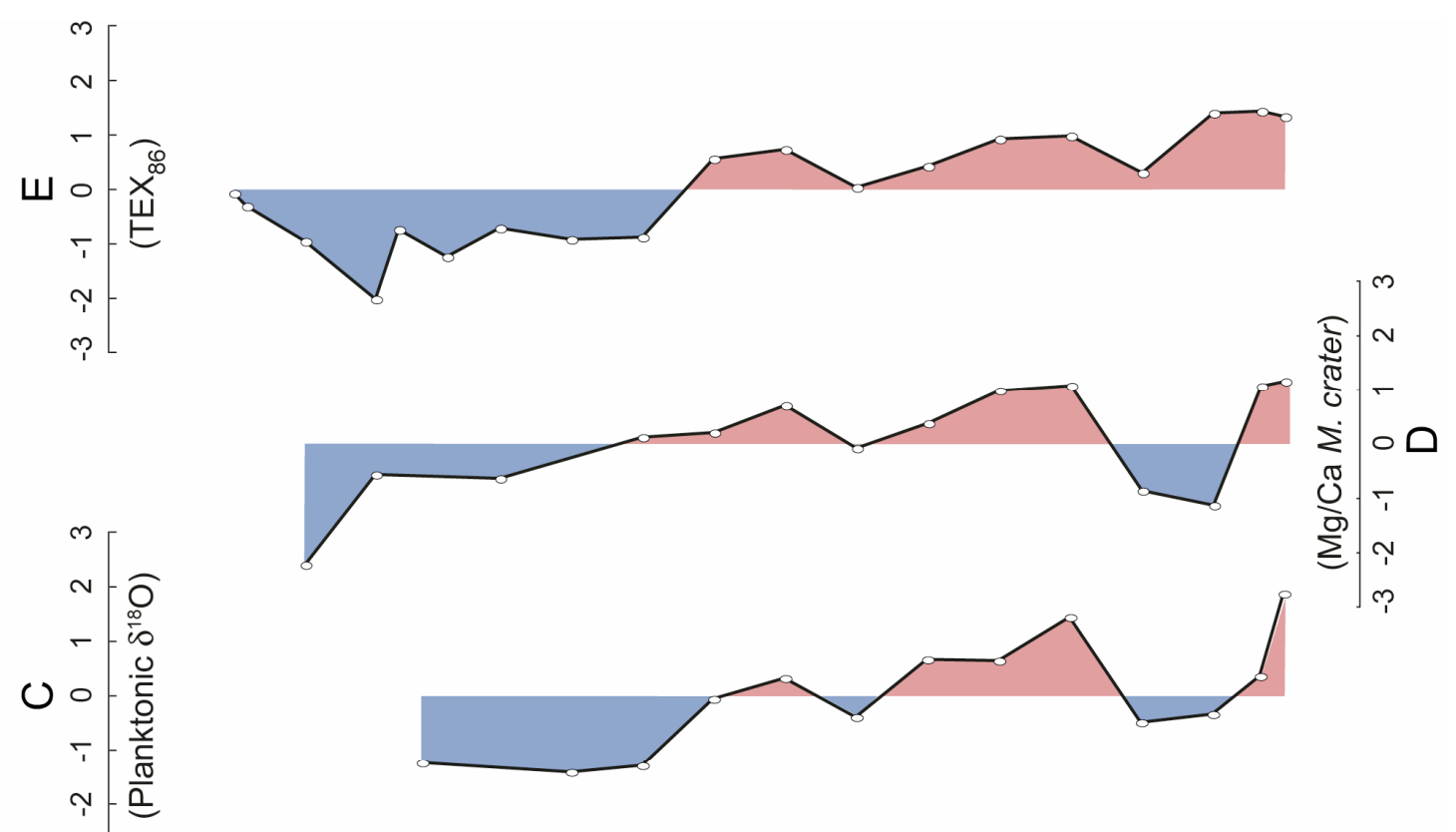

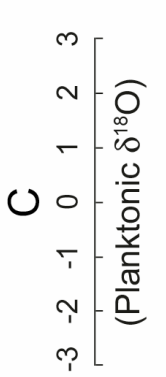
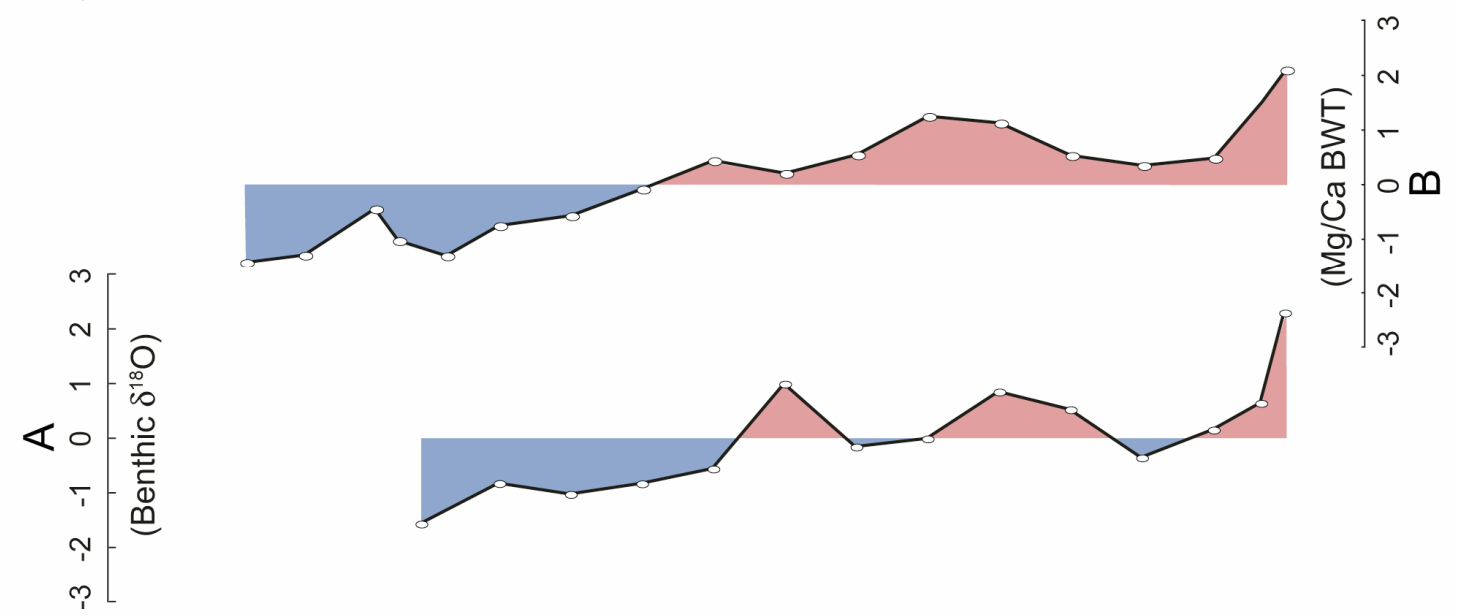

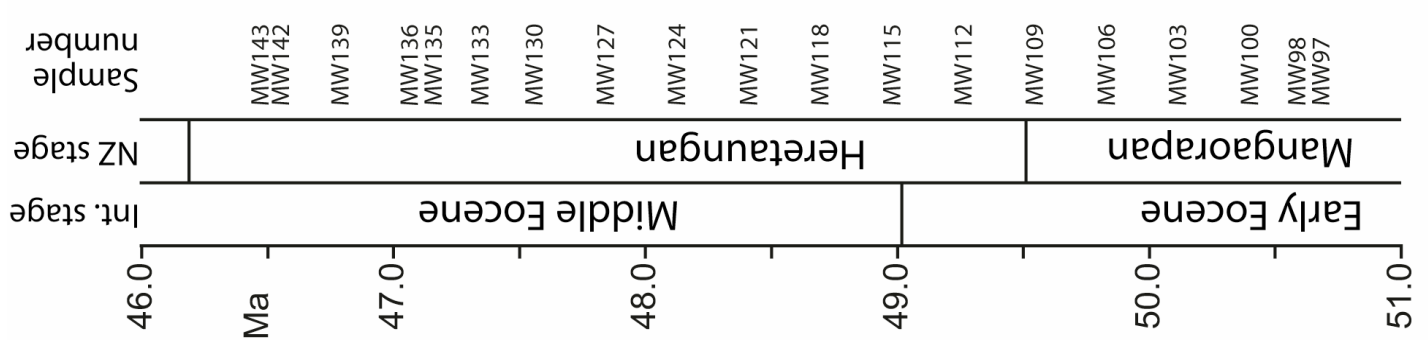


The strong agreement between the $\mathrm{Mg} / \mathrm{Ca}$ paleo-sea temperatures and two independent temperature proxies indicates that the laser ablation ICP-MS technique is effective in extracting reliable and meaningful temperatures even from what are, in some cases, relatively poorly preserved specimens. The similarity in the magnitude of reconstructed SST and BWT the proxies also suggest that the $\mathrm{Mg} / \mathrm{Ca}$-temperature calibrations from modern species appear to be applicable to Eocene species of foraminifera. 


\begin{tabular}{|c|c|c|c|c|c|c|c|c|}
\hline \multirow{2}{*}{$\begin{array}{l}\text { Sample } \\
\text { number }\end{array}$} & \multirow{2}{*}{ Age $(\mathrm{Ma})^{-}$} & \multicolumn{7}{|c|}{$\mathrm{Mg} / \mathrm{Ca}$ Temperatures } \\
\hline & & M.crater & A. primitiva & $\begin{array}{l}\text { Smoothed } \\
\text { SST }\end{array}$ & C. sp. A & $\begin{array}{c}\text { B. } \\
\text { subbortonica }\end{array}$ & V. marshalli & $\begin{array}{c}\text { Smoothed } \\
\text { BWT }\end{array}$ \\
\hline MW143 & 46.5 & & & & & & 16.0 & \\
\hline MW142 & 46.6 & & 25.6 & 25.6 & 13.5 & 17.3 & 14.7 & 14.5 \\
\hline MW139 & 46.8 & 23.3 & 27.0 & 26.7 & 14.1 & 16.1 & 13.9 & 14.7 \\
\hline MW136 & 47.1 & 26.4 & & 26.4 & 14.7 & 16.2 & 15.9 & 16.1 \\
\hline MW135 & 47.2 & & & & 13.8 & 16.0 & & 15.1 \\
\hline MW134 & 47.2 & & & & & & & \\
\hline MW133 & 47.3 & & 27.1 & 27.0 & 12.9 & 17.5 & 13.6 & 14.7 \\
\hline MW130 & 47.6 & 26.3 & 22.8 & 24.2 & 13.4 & 17.3 & 15.3 & 15.6 \\
\hline MW127 & 47.8 & & 30.6 & 28.0 & 14.2 & 16.8 & 16.2 & 15.8 \\
\hline MW124 & 48.1 & 27.7 & & 26.9 & 15.0 & 18.2 & 17.4 & 16.7 \\
\hline MW121 & 48.4 & 27.8 & 25.2 & 26.3 & 15.2 & 18.0 & 18.9 & 17.5 \\
\hline MW118 & 48.7 & 28.8 & 26.2 & 27.7 & 15.9 & 18.0 & 17.8 & 17.1 \\
\hline MW115 & 49.0 & 27.3 & 27.2 & 27.0 & & 16.9 & 18.2 & 17.7 \\
\hline MW112 & 49.3 & 28.2 & 26.7 & 27.0 & 19.5 & 18.1 & 19.2 & 18.8 \\
\hline MW109 & 49.5 & 29.3 & 25.0 & 26.0 & & 18.4 & 19.0 & 18.6 \\
\hline MW106 & 49.8 & 29.5 & 27.5 & 27.6 & 18.3 & 17.8 & 17.4 & 17.6 \\
\hline MW103 & 50.1 & 25.8 & 24.4 & 24.8 & & 14.1 & 17.7 & 17.3 \\
\hline MW100 & 50.4 & 25.4 & 28.7 & 27.4 & 17.1 & 16.5 & 18.6 & 17.6 \\
\hline MW98 & 50.6 & 29.4 & 29.3 & 29.4 & & & & \\
\hline MW97 & 50.7 & 29.6 & 28.0 & 29.3 & 20.7 & & 19.6 & 20.2 \\
\hline \multirow[b]{2}{*}{$\begin{array}{l}\text { Sample } \\
\text { number }\end{array}$} & \multirow[b]{2}{*}{ Age (Ma) } & \multicolumn{2}{|c|}{$\mathrm{TEX}_{86} \mathrm{SST}$} & & \multicolumn{2}{|c|}{$\delta^{18} \mathrm{O}$ (Ice-free) } & \multicolumn{2}{|c|}{$\delta^{18} \mathrm{O}$ (with ice) } \\
\hline & & $\begin{array}{c}\text { Kim et al. } \\
(2008) \\
\text { calibration }\end{array}$ & $\begin{array}{c}\text { Liu et al. } \\
(2009) \\
\text { calibration }\end{array}$ & & $\begin{array}{c}\text { SST } \\
\text { (Morozovella) }\end{array}$ & $\begin{array}{c}\text { BWT } \\
\text { (Cibicides) }\end{array}$ & $\begin{array}{c}\text { SST } \\
\text { (Morozovella) }\end{array}$ & $\begin{array}{c}\text { BWT } \\
\text { (Cibicides) }\end{array}$ \\
\hline MW143 & 46.5 & & & & & & & \\
\hline MW142 & 46.6 & 29.8 & 27.8 & & & & & \\
\hline MW139 & 46.8 & 28.2 & 27.0 & & & & & \\
\hline MW136 & 47.1 & 26.0 & 25.5 & & & & & \\
\hline MW135 & 47.2 & 28.7 & 27.2 & & & & & \\
\hline MW134 & 47.2 & & & & 21.2 & 14.5 & & \\
\hline MW133 & 47.3 & 27.6 & 26.6 & & & & & \\
\hline MW130 & 47.6 & 28.8 & 27.3 & & & 17.7 & & 20.5 \\
\hline MW127 & 47.8 & 28.3 & 27.0 & & 20.3 & 16.8 & 24.4 & 21.0 \\
\hline MW124 & 48.1 & 28.4 & 27.1 & & 20.9 & 17.7 & 25.4 & 22.1 \\
\hline MW121 & 48.4 & 32.0 & 29.0 & & 27.6 & 18.8 & 31.6 & 22.8 \\
\hline MW118 & 48.7 & 32.5 & 29.3 & & 29.6 & 25.4 & 29.6 & 25.4 \\
\hline MW115 & 49.0 & 30.6 & 28.3 & & 25.8 & 20.5 & 27.7 & 22.4 \\
\hline MW112 & 49.3 & 31.6 & 28.8 & & 31.5 & 21.2 & 34.2 & 23.8 \\
\hline MW109 & 49.5 & 33.0 & 29.5 & & 31.4 & 24.8 & 31.4 & 24.8 \\
\hline MW106 & 49.8 & 33.2 & 29.6 & & 35.7 & 23.4 & 35.7 & 23.4 \\
\hline MW103 & 50.1 & 31.3 & 28.7 & & 25.3 & 19.7 & 27.6 & 22.0 \\
\hline MW100 & 50.4 & 34.4 & 30.2 & & 26.1 & 21.9 & 26.8 & 22.6 \\
\hline MW98 & 50.6 & 34.5 & 30.2 & & 29.8 & 23.9 & & \\
\hline MW97 & 50.7 & 34.2 & 30.1 & & 38.0 & 31.0 & 38.0 & 31.0 \\
\hline
\end{tabular}

Table 3. Reconstructed $\mathrm{Mg} / \mathrm{Ca}$ sea temperatures for the full suite of mid-Waipara samples, including model SST and BWT generated from $\mathrm{Mg} / \mathrm{Ca}$ data, and comparative $\delta^{18} \mathrm{O}$ and $\mathrm{TEX}_{86}$ temperatures from the same samples (Hollis et al., 2009). Temperatures from TEX $_{86}$ are calculated from two different calibrations, which yield somewhat different temperatures. $\delta^{18} O$ temperatures are calculated using a fixed $\delta^{18} O_{\text {sw }}$ for an assumed ice-free world $\left(\delta^{18} \mathrm{O}_{\text {sw }}=-1 \%\right.$ ) and using calculated $\delta^{18} \mathrm{O}_{\text {sw }}$ reconstructed from $\mathrm{Mg} / \mathrm{Ca}$ temperature data, which allows for the presence of continental ice in the greenhouse. Note: As the temperatures from $M$. crater show a much better agreement with the other records than the planktonic model $(M$. crater $+A$. primitiva), and the planktonic $\delta^{18} \mathrm{O}$ is also based on Morozovella, the $\mathrm{M}$. crater $\mathrm{Mg} / \mathrm{Ca}$ record is the preferred $\mathrm{Mg} / \mathrm{Ca} \mathrm{SST}$ model.

\subsection{Implications for the seawater $\mathrm{Mg} / \mathrm{Ca}$ ratio in the Eocene ocean}

The $\mathrm{Mg} / \mathrm{Ca}$ value for Eocene seawater used in this study to calculate sea temperatures $(3.35 \mathrm{mmol} / \mathrm{mol})$ is a conservative value, and while Lear et al. (2002) argue that it is unlikely that $\mathrm{Mg} / \mathrm{Ca}_{\mathrm{sw}}$ would have been less than $3.35 \mathrm{mmol} / \mathrm{mol}$, published estimates from other models and proxies extend to values as low as 1.5- 
$2.0 \mathrm{mmol} / \mathrm{mol}$ (Hardie, 1996; Lowenstein et al., 2001; Stanley and Hardie, 1998; Dickson, 2002), which would raise $\mathrm{Mg} / \mathrm{Ca}$ sea temperatures by up to $10^{\circ} \mathrm{C}$ as compared to the values shown here (Tables 1, 2 and 3; Fig. 4a).

$\mathrm{TEX}_{86} \mathrm{SST}_{\mathrm{s}}$ are independent of the seawater $\mathrm{Mg} / \mathrm{Ca}$ ratio, and these can thus be used to constrain the $\mathrm{Mg} / \mathrm{Ca}$ values of seawater during the Eocene, including any potential significant changes over time (assuming that the $\mathrm{Mg} / \mathrm{Ca}$-temperature calibration is accurate for these Eocene foraminifera). However, comparison between $\mathrm{Mg} / \mathrm{Ca}$ and $\mathrm{TEX}_{86}$ SSTs is complicated by disagreement over temperature calibrations for $\mathrm{TEX}_{86}$. While there is good agreement between $\mathrm{Mg} / \mathrm{Ca}$ and TEX ${ }_{86} \mathrm{SST}_{\mathrm{s}}$ in terms of the timing and magnitude of temperature variations, the absolute $\mathrm{TEX}_{86}$ SST values depend on which calibration is used (Fig. 4b).

An Eocene $\mathrm{Mg} / \mathrm{Ca}_{\mathrm{sw}}$ of $3.35 \mathrm{mmol} / \mathrm{mol}$ (Lear et al., 2003), fixed throughout the duration of the record, results in a very close match between planktonic $\mathrm{Mg} / \mathrm{Ca}$ and $\mathrm{TEX}_{86}$ SSTs using the non-linear calibration of Liu et al. (2009). If the Liu et al. (2009) calibration is correct, this suggests that this $\mathrm{Mg} / \mathrm{Ca}$ sw is close to the true value. However, using the calibration of Kim et al. (2008), TEX $_{86}$ temperature estimates are higher by up to $4.5^{\circ} \mathrm{C}$ and show a greater cooling over the time interval, potentially implying our assumed $\mathrm{Mg} / \mathrm{Ca}_{\mathrm{sw}}$ is too conservative (i.e., high) and that $\mathrm{Mg} / \mathrm{Ca}$ sw has changed over the duration of the record. By adjusting the planktonic $\mathrm{Mg} / \mathrm{Ca} \mathrm{SST}$ data to match the $\mathrm{TEX}_{86}$ record, it is possible to estimate the required $\mathrm{Mg} / \mathrm{Ca}$ sw and its rate of change. Doing so requires $\mathrm{Mg} / \mathrm{Ca}_{\mathrm{sw}}$ to be $2.24 \mathrm{mmol} / \mathrm{mol}$ at the bottom of the record increasing to $3.04 \mathrm{mmol} / \mathrm{mol}$ by the top of the record (assuming the change in $\mathrm{Mg} / \mathrm{Ca}$ sw to be linear), and results in a good fit between SSTs derived from $\mathrm{Mg} / \mathrm{Ca}$ and $\mathrm{TEX}_{86}$ calculated with the Kim et al. (2008) calibration. Applying the same $\mathrm{Mg} / \mathrm{Ca}$ sw values to the benthic $\mathrm{Mg} / \mathrm{Ca}$ data also increases BWT estimates, and improves the agreement between the benthic $\mathrm{Mg} / \mathrm{Ca}$ and $\delta^{18} \mathrm{O}$ records. However, the implied rate of change in $\mathrm{Mg} / \mathrm{Ca}_{\mathrm{sw}}$ of $0.19 \mathrm{mmol} / \mathrm{mol}$ per Myr is significantly steeper than modelled estimates, which predict a maximum rate of ca. $0.08 \mathrm{mmol} / \mathrm{mol} / \mathrm{Myr}$ (Wilkinson and Algeo, 1989; Stanley and Hardie, 1998).

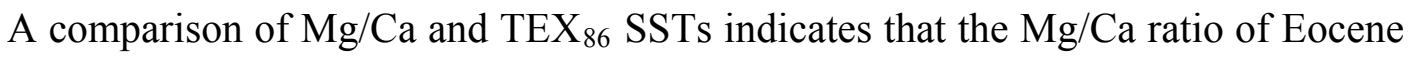
seawater is unlikely to have been lower than $2 \mathrm{mmol} / \mathrm{mol}$ because lower estimates of seawater $\mathrm{Mg} / \mathrm{Ca}$ increase reconstructed $\mathrm{Mg} / \mathrm{Ca}$ paleo-sea temperatures beyond the range suggested by two independent temperature proxies. Recently, Coggon et al. (2010) 
published a record of Mesozoic and Cenozoic seawater $\mathrm{Mg} / \mathrm{Ca}$ and $\mathrm{Sr} / \mathrm{Ca}$ ratios extending back to $c a$. 170 Ma based on trace element concentrations from mid-ocean ridge flank calcium carbonate veins. The estimates from Coggon et al. (2010) of Paleogene seawater $\mathrm{Mg} / \mathrm{Ca}$ range from 1.2-2.5 mmol/mol. The sensitivity of the $\mathrm{Mg} / \mathrm{Ca}$ paleothermometer to changes in the $\mathrm{Mg} / \mathrm{Ca}$ ratio of seawater is shown in Fig. 6. Based on our $\mathrm{Mg} / \mathrm{Ca}$ data, seawater $\mathrm{Mg} / \mathrm{Ca}$ ratios of $<1.5 \mathrm{mmol} / \mathrm{mol}$ have the effect of increasing reconstructed $\mathrm{Mg} / \mathrm{Ca}$ temperatures by $7.5-11.5^{\circ} \mathrm{C}$ (Fig. 6), resulting in temperatures that seem implausibly high $\left(36-41^{\circ} \mathrm{C}\right)$, especially considering temperatures from $\mathrm{TEX}_{86}$. Additionally, seawater $\mathrm{Sr} / \mathrm{Ca}$ ratios from Coggon et al. (2010) are estimated at $\mathrm{Sr} / \mathrm{Ca}=2.8 \pm 1 \mathrm{mmol} / \mathrm{mol}$ (i.e. 3 times lower than the present day). By inverting the $\mathrm{Sr} / \mathrm{Ca}$ partition coefficient between seawater and foraminiferal calcite from Lear et al. (2003) $\left(\mathrm{D}_{\mathrm{Sr}}=0.165\right)$, the Eocene seawater $\mathrm{Sr} / \mathrm{Ca}$ of Coggon et al. (2010) should be reflected by foraminiferal $\mathrm{Sr} / \mathrm{Ca}$ ratios of $0.3-0.6 \mathrm{mmol} / \mathrm{mol}$. Foraminiferal $\mathrm{Sr} / \mathrm{Ca}$ ratios measured in this study are generally in the range $1.0-1.4 \mathrm{mmol} / \mathrm{mol}$, which is consistent with observations in previous trace element studies of Eocene foraminifera (Lear et al., 2003; Tripati et al., 2003), and thus the results of this study are inconsistent with the Eocene seawater $\mathrm{Sr} / \mathrm{Ca}$ and $\mathrm{Mg} / \mathrm{Ca}$ reconstructions of Coggon et al. (2010). 


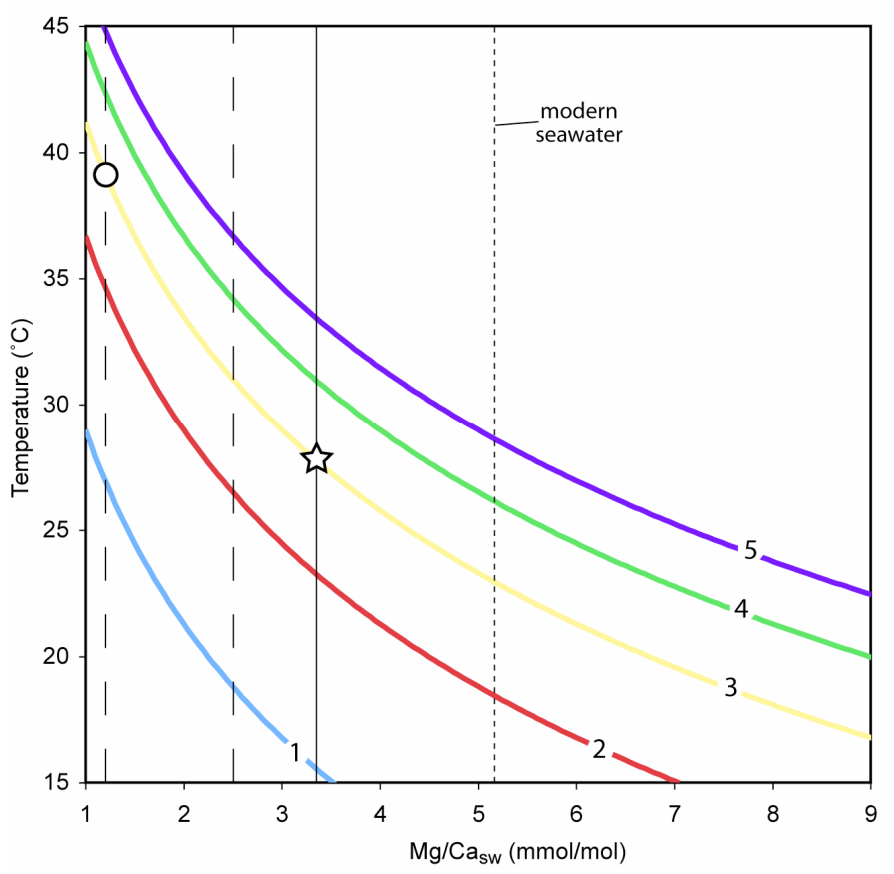

Figure 6. Graphical illustration of the sensitivity of temperature reconstructions to seawater $\mathrm{Mg} / \mathrm{Ca}$ ratios. The contours represent planktonic foraminiferal $\mathrm{Mg} / \mathrm{Ca}$ ratios in $\mathrm{mmol} / \mathrm{mol}$, converted to temperature using the planktonic calibration of Anand et al. (2003). The vertical lines represent seawater $\mathrm{Mg} / \mathrm{Ca}$ values: dotted black line $=$ Modern seawater $\mathrm{Mg} / \mathrm{Ca}$ (Lear et al., 2003); solid black line = Lear et al. (2003) estimate of minimum Eocene seawater $\mathrm{Mg} / \mathrm{Ca}(=3.35 \mathrm{mmol} / \mathrm{mol})$, which was used for the calculation of temperatures in this study; dashed black lines = upper and lower limit of seawater $\mathrm{Mg} / \mathrm{Ca}$ for the period 170-24 Ma from Coggon et al. (2010). The open star represents the intersection between the mean $\mathrm{Mg} / \mathrm{Ca}$ ratio of the planktonic foraminifera species $M$. crater from mid-Waipara and the assumed $\mathrm{Mg} / \mathrm{Ca} \mathrm{a}_{\mathrm{sw}}$ from Lear et al. (2003). The open circle represents the maximum temperature estimate based on the intersection between the mean $\mathrm{Mg} / \mathrm{Ca}$ ratio of the planktonic foraminifera species $M$. crater from mid-Waipara and the lower estimate of $\mathrm{Mg} / \mathrm{Casw}$ from Coggon et al. (2010). Thus, for the measured $\mathrm{Mg} / \mathrm{Ca}$ ratios at mid-Waipara, using a seawater $\mathrm{Mg} / \mathrm{Ca}$ value of $1.2 \mathrm{mmol} / \mathrm{mol}$ increases $\mathrm{Mg} / \mathrm{Ca}$ SST estimates by ca. $11.5^{\circ} \mathrm{C}$ above the assumed value of $3.35 \mathrm{mmol} / \mathrm{mol}$, yielding sea surface temperatures of ca. $35-40^{\circ} \mathrm{C}$. For benthic foraminifera, a seawater $\mathrm{Mg} / \mathrm{Ca}$ ratio of $1.2 \mathrm{mmol} / \mathrm{mol}$ increases temperatures by $9-10^{\circ} \mathrm{C}$ above those calculate using the assumed value of $3.35 \mathrm{mmol} / \mathrm{mol}$, yielding bottom water temperatures of $23-30^{\circ} \mathrm{C}$.

\subsection{Comparison with oxygen isotope data}

The oxygen isotope temperature record from the Ashley Mudstone is observed to vary sympathetically with temperatures derived from $\mathrm{Mg} / \mathrm{Ca}$ and $\mathrm{TEX}_{86}$ throughout the studied interval. However, the $\delta^{18} \mathrm{O}$-temperature record exhibits larger amplitude fluctuations than the other temperature proxies (Fig. 4). These fluctuations are observed in both the planktonic and benthic $\delta^{18} \mathrm{O}$ records, and it is therefore unlikely that local evaporation and salinity effects are responsible for the amplified temperature changes. 
An explanation for this increase in amplitude requires a mechanism that can amplify both positive and negative $\delta^{18} \mathrm{O}$ excursions while preserving the primary trend in temperature.

A diagenetic explanation requires that post-depositional diagenetic processes were acting to different degrees over the record, i.e. that foraminifera deposited during warm intervals were better preserved (less diagenetically altered) than those deposited during cooler intervals. This could occur as a result of the deposition of more clay-rich sediment during warmer periods, which would lead to better preservation of foraminifera, while foraminifera deposited in cooler periods would be more susceptible to diagenesis. As diagenetic effects generally have the effect of lowering $\delta^{18} \mathrm{O}$ temperatures, this would amplify the cooling signal.

Another mechanism that could amplify the $\delta^{18} \mathrm{O}$-temperature signal without overprinting it and maintain synchronous variations between the three temperature proxies, would be if $\delta^{18} \mathrm{O}$ of seawater varied during this time interval (i.e. in response to the waxing and waning of continental ice sheets). In oxygen isotope temperature reconstructions, the Early Eocene Earth is often considered to have been free of significant continental ice, and temperatures are calculated assuming an "ice-free world" seawater $\delta^{18} \mathrm{O}$ value. However, if small ephemeral ice sheets were forming and collapsing in polar regions during this time, a signal should be preserved in the $\delta^{18} \mathrm{O}$ record. Given increasing evidence for polar ice sheets in the Eocene (Peters et al., 2010), it is possible the some of the high amplitude variation in $\delta^{18} \mathrm{O}$ observed in the Mid-Waipara section reflects changes in seawater $\delta^{18} \mathrm{O}$ as a consequence of waxing and waning Eocene ice sheets. Using an independent record of temperature (such as $\mathrm{Mg} / \mathrm{Ca}$ ), the temperature component can be subtracted from the $\delta^{18} \mathrm{O}$ record, yielding the $\delta^{18} \mathrm{O}$ of seawater (e.g. Lear et al., 2000; supplementary information). The $\delta^{18} \mathrm{O}_{\text {sw }}$ calculated in this way is shown in Figure 4D and the effect on the $\delta^{18} \mathrm{O}$ temperature record can be seen in Figure 4C. Allowing the $\delta^{18} \mathrm{O}_{\mathrm{sw}}$ to change in this way improves the match between $\delta^{18} \mathrm{O}$ and the other proxies.

The changes in $\delta^{18} \mathrm{O}_{\text {sw }}$ can be converted into an approximate ice volume. If ice sheets were present in the Early Eocene, they would have had a heavier isotopic composition than the present day (e.g. ca. -35\%o; Pekar and DeConto, 2006) due the warmer climate. Using an oxygen isotope - ice-volume calibration for the Miocene (0.35\% per $10 \mathrm{~m}$ apparent sea level change; Pekar and DeConto, 2006), the back- 
calculated $\delta^{18} \mathrm{O}_{\text {sw }}$ record would imply growth and collapse of ice sheets driving 15 - 30 $m$ changes in sea level (Fig. 4D). Sea-level changes of this magnitude are consistent with estimates based on back stripping (Haq et al., 1987; Kominz et al., 1998, 2008; Miller et al., 2003, 2005b; Pekar et al., 2005; Browning et al., 2008; Müller et al., 2008), which have shown pre-Oligocene changes in sea level that are too large and rapid to result from any other process than glacioeustacy (Miller et al., 2005a).

The presence of significant ice sheets in the earlier Eocene remains the subject of ongoing debate. Our record shows the possibility of some ice-volume influence on the $\delta^{18} \mathrm{O}$ of carbonates. However, it is possible that the observed amplification of $\delta^{18} \mathrm{O}$ temperatures arises from diagenetic effects. Further high-resolution multiproxy studies of early Paleogene records, including in-situ analysis of different proxies in individual microfossils, may help to resolve this debate.

\subsection{Cenozoic changes in the redox state of the ocean revealed through foraminiferal}

\section{$\mathrm{Mn} /$ Ca ratios?}

The manganese content of foraminifera is generally thought to reflect secondary diagenetic processes occurring on the seafloor, and the precipitation of $\mathrm{Mn}$ carbonate and oxyhydroxide phases at the sediment-water interface (Boyle, 1983; Pingitore et al., 1988; Lea et al., 1999) or in the sediment column (Wei et al., 2009). These phases are important in redox reactions in suboxic environments (Pingitore et al., 1988), and thus $\mathrm{Mn} / \mathrm{Ca}$ ratios are significantly higher in reducing sediments, where remobilised $\mathrm{Mn}$ and Fe are precipitated as oxides or oxyhydroxides (Boyle, 1983). The deposition of authigenic Fe-Mn oxyhydroxide phases in the ocean is largely controlled by redox conditions, which in turn depend on the amount of organic carbon deposition.

In mid-Waipara samples, mean benthic and planktonic foraminiferal $\mathrm{Mn} / \mathrm{Ca}$ values show a decrease of $60-90 \%$ (e.g. $\mathrm{Mn} / \mathrm{Ca}=c a .0 .5-0.08 \mathrm{mmol} / \mathrm{mol})$ over the period 51$46 \mathrm{Ma}$. The interpretation of this is not entirely straightforward. The change in $\mathrm{Mn} / \mathrm{Ca}$ accompanies a change in foraminifer preservation up-section. However, preservation is observed to decrease up-section. If the preservation also reflects the level to which those foraminifera were prone to diagenesis (which is inferred to be the case from laser ablation data), then logically one might expect the opposite trend in $\mathrm{Mn} / \mathrm{Ca}$ (i.e. an increase up section). While this observation does not preclude Mn-rich coatings as the 
source of $\mathrm{Mn} / \mathrm{Ca}$ ratios, an alternative hypothesis could be that $\mathrm{Mn} / \mathrm{Ca}$ is a primary feature, where $\mathrm{Mn}^{2+}$ has been incorporated into the calcite lattice during the precipitation of the foraminifera test. While $\mathrm{Mn}$ is present throughout laser ablation depth profiles (Fig. 3), which would be consistent with $\mathrm{Mn} / \mathrm{Ca}$ being a primary feature, the same is also true of $\mathrm{Al} / \mathrm{Ca}$, which is inferred to be present from sediment infilling pore spaces. Thus, it is not possible to say with absolute confidence whether $\mathrm{Mn} / \mathrm{Ca}$ ratios here reflect the presence of Mn-rich coatings occupying pore spaces, or whether it is a primary signal and thus might record the chemistry of the water column in which these foraminifera were living.

If $\mathrm{Mn}$-rich coatings are responsible for $\mathrm{Mn} / \mathrm{Ca}$ compositions, we can place some constraints on their chemistry. A weak correlation is observed between $\mathrm{Mn} / \mathrm{Ca}$ and $\mathrm{Mg} / \mathrm{Ca}$ (Table 2). However, linear regressions through $\mathrm{Mg} / \mathrm{Ca}$ versus $\mathrm{Mn} / \mathrm{Ca}$ data from the different species all have very low slopes, and do not converge towards a common end member. This means that if a mixed Ca-Mn-Mg carbonate phase (e.g. Boyle, 1983; Pena et al., 2005; Weldeab et al., 2006) was the contributor of Mn, they do not appear to have caused any significant bias to $\mathrm{Mg} / \mathrm{Ca}$ temperatures. If, rather, manganese oxyhydroxide coatings were the source of $\mathrm{Mn}$, the weak correlation observed between $\mathrm{Mg} / \mathrm{Ca}$ and $\mathrm{Mn} / \mathrm{Ca}$ may be merely a coincidence, whereby a cooling of sea temperatures directly caused a decrease in foraminifera $\mathrm{Mg} / \mathrm{Ca}$ ratios, and indirectly caused a reduction in $\mathrm{Mn} / \mathrm{Ca}$ ratios via an accompanying change in ocean redox conditions.

Regarding the implications for the redox conditions of the local basin, a decrease in the precipitation of Mn-rich contaminant phases would be expected to indicate a shift to a more oxidizing environment, i.e. a decrease in the burial of organic matter. However, this is inconsistent with a shift in carbon isotopes in planktonic foraminifera towards more positive values (Hollis et al., 2009), which indicates an increase in the export of marine organic matter from the surface ocean over the same period. An alternative explanation may come from a study of thallium (Tl) isotopes in ferromanganese crusts for the last ca. $74 \mathrm{Ma}$ (Nielsen et al., 2009), which has shown that the rate of precipitation of authigenic Fe-Mn oxyhydroxides was several times higher in the Paleocene than for the remainder of the Cenozoic, and that most of the change between the two regimes occurred over the period 55 - $45 \mathrm{Ma}$ (i.e. the same time period covered by the mid-Waipara record). $\mathrm{Mn} / \mathrm{Ca}$ data from mid-Waipara and another LA-ICP-MS data set from modern foraminifera specimens (Marr, 2009) are shown overlain on the 
$\varepsilon^{205} \mathrm{Tl}$ data of Nielsen et al. (2009) (Fig. 7). Nielsen et al. attribute the reduced sequestration of $\mathrm{Tl}$ by Fe-Mn oxyhydroxides to greatly increased biological utilization of Fe and $\mathrm{Mn}$ and increased marine organic carbon burial since the Paleocene.

Thus, the decrease in the $\mathrm{Mn} / \mathrm{Ca}$ content of foraminifera over the mid-Waipara record may reflect reduction in the precipitation of manganese carbonate and oxyhydroxide coatings caused by the reduced availability of Fe- $\mathrm{Mn}$ in seawater, brought about by increased ocean productivity, which is consistent with the observed cooling. This is also consistent with the increased organic matter burial indicated by carbon isotopes (Hollis et al., 2009). Such an argument may satisfy either possibility for the source of $\mathrm{Mn}$ - a reduction in the availability of $\mathrm{Mn}$ in seawater would limit the availability for both precipitation from the water column, or for the formation of Mnoxyhydroxide coatings. This interpretation is tenuous however, given that the substitution of $\mathrm{Mn}$ into calcite is not well understood, and additionally the residence time of $\mathrm{Mn}$ in the ocean is short and thus changes in $\mathrm{Mn} / \mathrm{Ca}$ may not reflect global processes. However given the consistency between modern foraminiferal $\mathrm{Mn} / \mathrm{Ca}$ data (Marr, 2009), Eocene foraminiferal $\mathrm{Mn} / \mathrm{Ca}$ data from mid-Waipara (this study), and the thallium isotope data of Nielsen et al. (2009) for the same period, there appears to be grounds for a common interpretation. 


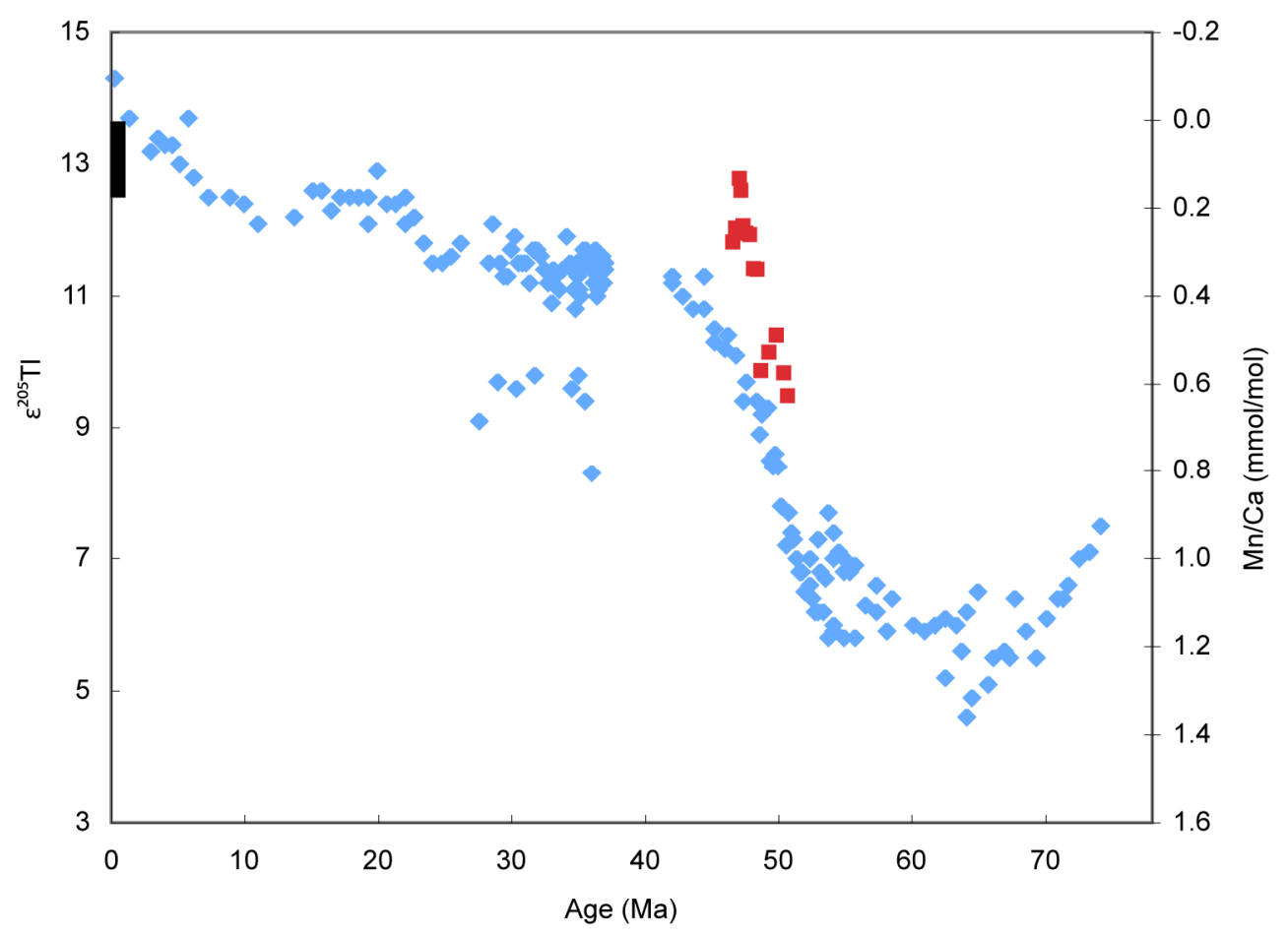

Figure 7. Mn/Ca data from mid-Waipara (red squares; this study). The range of $\mathrm{Mn} / \mathrm{Ca}$ ratios found in modern foraminifera analysed by LA-ICP-MS (black rectangle; Marr, 2009) is also shown, and these are superimposed on thallium isotope data (blue diamonds) from Nielsen et al. (2009). The dramatic change in $\varepsilon^{205} \mathrm{Tl}$ from 55 - 45 Ma was interpreted by Nielsen et al. to reflect four times greater sequestration of $\mathrm{Fe}$ and $\mathrm{Mn}$ in the ocean by biological utilization. Mn/Ca data for the Cenozoic appears to support this hypothesis, with the major change in $\mathrm{Mn} / \mathrm{Ca}$ occurring over the same period, which is covered by the mid-Waipara record. In the mid-Waipara data, $\mathrm{Mn} / \mathrm{Ca}$ ratios decrease by $60-90 \%$ between 55 and 45 Ma.

\subsection{Implications for global climate}

Three independent geochemical proxies yield tropical sea temperatures for New Zealand's Canterbury Basin during the Early Eocene with SSTs of $26-30^{\circ} \mathrm{C}$ and BWTs of $16-20^{\circ} \mathrm{C}$ in the bathyal setting at mid-Waipara. These temperatures are similar to other published SST estimates from lower latitude deep-sea cores for the Early to Middle Eocene (Tripati et al., 2003; Sexton et al., 2006) and from the Paleocene-Eocene thermal maximum (Zachos et al., 2006). Some significant climate events are common to all of these proxy records, which are highlighted by the normalized records in Fig. 5. A transient event is observed in SST and BWT in all proxy records between ca. 50.5 and 50.0 Ma, with a cooling of $c a .4^{\circ} \mathrm{C}$ in sea surface temperatures. Given the amplified oxygen isotope signal, the cooling in BWT was probably closer to the $2-3^{\circ} \mathrm{C}$ indicated by the $\mathrm{Mg} / \mathrm{Ca} \mathrm{BWT}$ record. This cooling took place over $c a$. $0.6 \mathrm{Myr}$, reaching a local 
minimum at around 50.2 Ma. While this transient cooling of $c a .4^{\circ} \mathrm{C}$ at mid-Waipara may not reflect a global cooling of that magnitude, the fact that it affected both sea surface and bottom water temperatures means that it is unlikely to be a localized phenomenon, and this cooling may represent a global climate event.

A cooling trend is observed from ca. $48.7 \mathrm{Ma}$ onwards in reconstructed temperatures from all three of the temperature proxies. We interpret this final cooling event as the termination of the EECO for the southern-mid latitudes, and the beginning of the greenhouse to icehouse transition. By $46.5 \mathrm{Ma}$, SSTs drop to below ca. $24^{\circ} \mathrm{C}$ and BWTs to below $15^{\circ} \mathrm{C}$. The timing of the termination of the EECO at mid-Waipara is generally consistent with the hypothesis that blooms of the Azolla fern in fresh surface waters of the geographically restricted Eocene Arctic Ocean may have drawn down significant amounts of atmospheric $\mathrm{CO}_{2}$ triggering the transition to the icehouse world (Brinkhuis et al., 2006; Speelman et al., 2009). 


\section{Conclusions}

A LA-ICP-MS study of the trace element chemistry of Eocene (51-46 Ma) planktonic and benthic foraminifera from mid-Waipara, southern New Zealand has shown that:

(1) This technique can extract reliable $\mathrm{Mg} / \mathrm{Ca}$ paleo-sea temperature data from Eocene foraminifera, even from moderately poorly preserved specimens, as demonstrated by agreement with sea surface and bottom water temperature data from two independent proxies $\left(\mathrm{TEX}_{86}\right.$ and $\left.\delta^{18} \mathrm{O}\right)$.

(2) The agreement between proxies also indicates that the $\mathrm{Mg} / \mathrm{Ca}$-temperature calibrations from modern species appear to be applicable to Eocene foraminifera.

(3) During the EECO, sea surface temperatures at mid-Waipara (paleo-latitude ca. $55^{\circ} \mathrm{S}$ ) were $28-30^{\circ} \mathrm{C}$, and bottom water temperatures were $18-20^{\circ} \mathrm{C}$. Temperatures were generally consistent for the period ca. 51-48.7 Ma with the exception of a 0.5 Myr transient cooling of $3-4^{\circ} \mathrm{C}$ between $\mathrm{ca}$. 50.5 and $50.0 \mathrm{Ma}$, and then sea temperatures steadily declined from ca. 48.7 Ma until the end of the record at 46.5 Ma. A net cooling of $c a .6^{\circ} \mathrm{C}$ is observed over the entire mid-Waipara record.

(4) Reconstructed $\mathrm{Mg} / \mathrm{Ca}$ paleo-sea temperatures show excellent agreement with $\mathrm{TEX}_{86}$ temperatures, which provides constraints on estimates of the $\mathrm{Mg} / \mathrm{Ca}$ of Eocene seawater. The value of seawater $\mathrm{Mg} / \mathrm{Ca}$ depends on the $\mathrm{TEX}_{86}$ temperature calibration used, but is in the range $2.24-3.35 \mathrm{mmol} / \mathrm{mol}$.

(5) Comparison between paleo-sea temperatures from $\mathrm{Mg} / \mathrm{Ca}$ and oxygen isotope data implies that seawater $\delta^{18} \mathrm{O}$ changed significantly over the mid-Waipara record. While the oxygen isotope signal has almost certainly been disturbed to some extent by diagenesis, the $\delta^{18} \mathrm{O}_{\mathrm{sw}}$ record provides some evidence for the presence of transient continental ice sheets on Antarctica during the Early Eocene greenhouse.

(6) The termination of the EECO and the beginning of the transition from greenhouse to icehouse conditions occurred at $c a$. $48.7 \mathrm{Ma}$, approximately concurrent with the 'Azolla interval' in the Arctic Ocean, supporting the hypothesis that this event drew down significant amounts of atmospheric $\mathrm{CO}_{2}$ and triggered the cooling that followed. 


\section{References}

The references for this manuscript have been incorporated into the reference list in Chapter 6. 


\section{SUPPLEMENTARY RESULTS AND DISCUSSION}

\subsection{Introduction}

Due to manuscript length requirements for submission to Earth and Planetary Science Letters, not all of the results from this study could be incorporated into the manuscript in Chapter 3. This chapter covers some findings from this study that had to be omitted from Chapter 3. This chapter will discuss which Eocene foraminifera species are best suited to this method of trace element analysis, how the inter-species calibrations used in Chapter 3 were derived, additional trace element data from midWaipara, and the advantages and disadvantages of the laser ablation technique. An extended discussion of the draw down of $\mathrm{CO}_{2}$ in the Arctic Ocean cited as a potential trigger for the climatic cooling in the middle Eocene in Chapter 3 is also included.

\subsection{Mg/Ca Paleothermometry by LA-ICP-MS}

\subsubsection{Comparison of Foraminifera Species for LA-ICP-MS analysis}

A number of studies of Paleogene climate have utilized Eocene foraminifera in $\mathrm{Mg} / \mathrm{Ca}$ paleoclimate reconstructions (e.g. Lear et al., 2000, 2002, 2003; Tripati et al., 2003; Sexton et al., 2006, Pearson et al., 2007). However, most of the foraminifera species analysed in this study have not been used previously, and particularly not with in situ analytical techniques. Laser ablation ICP-MS trace element profiles were found to vary significantly, reflecting the positioning of the laser ablation spot and the differing characteristics of tests from different species of foraminifera, such as shape, density, porosity, thickness and ornamentation. Certain species routinely yielded particularly good trace element depth profiles, while others were found to be less useful. A brief summary of these findings is reported here.

Thirteen different species were analysed as part of this study, and the complete set of depth profiles is presented in Appendix 2, including scanning electron microscope (SEM) images showing the positions of laser spots. Comparison of laser spots with their respective trace element profiles demonstrates how the profiles were disturbed by ablation of ornamentations, overgrowths, or inclined surfaces. In the lower part of the section where the foraminiferal preservation is better, pores and ornamentation are 
preserved on test surfaces. Analyses of planktonic taxa often had high $\mathrm{Al} / \mathrm{Ca}$ ratios, which is thought to represent detrital sediment that is not effectively removed from pore spaces during the cleaning procedure. Trace element profiles from planktonic species were generally more variable than those from benthic species due to the ablation of ornamentations, pores and inclined surfaces.

Amongst the planktonic taxa, the Morozovellids had relatively high relief (Plate 1.1; Appendix 2), and positioning spots on horizontal surfaces was often difficult. However, where laser pits were favourably positioned, these taxa yielded good depth profiles (Figure 2.2; Appendix 2). The Acarininids offered more horizontal surfaces than the Morozovellids, and SEM images reveal much cleaner laser pits as a result. However, the good portions of the profiles from these taxa were generally slightly shorter than for the Morozovellids, indicating that the laser penetrated the thickness of the test walls more rapidly. Similarly, laser pits on tests of the species G. wilcoxensis appear very clean, however, the laser appears to penetrate these tests very quickly, with analyses consistently only yielding a very short useful profile. Specimens of M. crater and A. primitiva were found in almost all of the mid-Waipara samples (Appendix 1), making them more favourable for the temperature-time record.

Tests from benthic taxa were generally flatter, smoother and thicker walled, resulting in more effective ablation and better trace element profiles with longer useable segments. Tests from the species $A$. visenda have large deep pores that can affect laser ablation profiles depending on the positioning of laser pits. This species often produced good profiles, but was not present in many of the mid-Waipara samples (Appendix 1). B. subbortonica tests are generally very smooth and ablate well. The laser appears to have penetrated very quickly in a number of analyses, however, in general this species produced good depth profiles. B. subbortonica was found in most of the mid-Waipara samples. $N$. carinotruempyi had relatively high relief amongst benthic species, where analyses of inclined surface resulted in a number of poor depth profiles, and was also not present in many mid-Waipara samples. V. marshalli consistently produced good trace element profiles where the usable segment comprised almost the entire analysis, and was present in most mid-Waipara samples. Cibicidoides tests were more porous than most of the other benthic taxa (Plate 1.1), but generally yielded very good trace element profiles. C. pre-parki tests have surface ornamentations. Analyses of these decorations consistently produced unusable trace element depth profiles, making that 
species less suitable for laser ablation analyses. C. sp. A does not have ornamentation, and was present in most mid-Waipara samples. E. hampdenense was not present before the sample MW115, and thus was only measured from the sample MW118. E. hampdenense tests have very textured and ornamented surfaces, which result in variable depth profiles, however the very thick walls are generally reflected by long good segments in the later parts of the depth profiles (Appendix 2).

\subsubsection{Inter-species Calibrations}

Systematic offsets observed in $\mathrm{Mg} / \mathrm{Ca}$ ratios between the species of foraminifera were described in Chapter 3, which reflect differences in the uptake of $\mathrm{Mg}$ between species, and result in artificial differences in calculated temperatures between species that shared a common habitat. Given the inability to produce individual calibrations from extinct species, $\mathrm{Mg} / \mathrm{Ca}$ ratios were converted to temperatures using general calibrations from modern species for all benthic and planktonic species (Sections 1.4.1, 2.4).

There are several possible approaches by which these differences can be corrected: 1- systematic differences can be corrected by adjusting for the mean offset in either $\mathrm{Mg} / \mathrm{Ca}$ or temperature (practically identical as temperatures are directly proportional to $\mathrm{Mg} / \mathrm{Ca}$ ratios within each calibration group) from a particular species (Lear et al., 2000); or 2- the pre-exponential constant $(A)$ in the $\mathrm{Mg} / \mathrm{Ca}$ temperature equation can be adjusted such that the calculated temperature matches some independently derived (e.g. $\delta^{18} \mathrm{O}$ ) temperature (Lear et al., 2000). As calculated $\mathrm{Mg} / \mathrm{Ca}$ temperatures from planktonic species were relatively consistent and were found to match well with independently derived $\mathrm{TEX}_{86}$ temperatures, no correction was ultimately applied to SSTs (although correction factors were still calculated from $M$. crater). The only independent record of BWT was derived from $\delta^{18} \mathrm{O}$, which, as discussed in Chapter 3, were somewhat disturbed. Thus, benthic temperatures were corrected by adjusting temperatures from benthic species by their mean offsets from the species $C$. kurinuia in the three well-characterized samples (MW106, MW112, and MW118).

As $\delta^{18} \mathrm{O}$ data had already been measured from foraminifera of the genera Morozovella and Cibicides (Hollis et al., 2009), and because the benthic calibration utilized was also based species from the genus Cibicides (Lear et al., 2002), 
Morozovella crater and Cibicides kurinuia were selected as the normalizing species for planktonic and benthic taxa, respectively. The temperatures and typical offsets from the normalizing species are shown in Table 4.1.

$\begin{array}{lcccc} & \text { MW118 } & \text { MW112 } & \text { MW106 } & \text { Mean offset }^{\dagger} \\ \text { M. crater } & 28.8 & 28.2 & 29.5 & \mathbf{0 . 0} \\ \text { M. lensiformis } & 28.1 & 25.6 & 28.8 & -1.3 \\ \text { A. primitiva } & 26.1 & 27.8 & 27.5 & -1.7 \\ \text { A. collactea } & 30.3 & 30.1 & 31.4 & 1.8 \\ \text { G. wilcoxensis } & 28.7 & 29.8 & 28.5 & 0.2 \\ & & & & \\ \text { A. visenda } & 15.7 & & 20.0 & 0.9 \\ \text { B. subbortonica } & 17.2 & 17.3 & 16.9 & -0.7 \\ \text { V. marshalli } & 24.4 & 25.9 & 24.0 & 7.0 \\ \text { N. carinotruempyi } & 6.4 & 7.5 & & -10.6 \\ \text { C. kurinuia } & 15.6 & 19.5 & 18.3 & \mathbf{0 . 0} \\ \text { C. collinsi } & & 19.1 & 21.8 & 1.6 \\ \text { C. pre-parki } & 16.1 & 16.6 & 18.1 & -0.9 \\ \text { E hampdenense } & 14.0 & & & -1.6\end{array}$

Table 4.1. Mg/Ca temperatures from Eocene planktonic and benthic foraminifera in the three samples MW106, MW112 and MW118, and mean offsets from the normalizing species $M$. crater (planktonic), and $C$. kurinuia (benthic) in bold. Mean offsets in these samples were used to arbitrarily normalize temperatures in the temperature-time record (Chapter 3). ${ }^{\dagger}$ from normalizing species.

Relatively small offsets were observed amongst planktonic species, indicating that the multi-species planktonic calibration used (Anand et al., 2003) is effective for Eocene planktonic foraminifera. Large systematic offsets were observed for some benthic foraminifera species (N. carinotruempyi, V. marshalli) (Table 4.1) resulting in a much wider apparent temperature range. The cross calibration is effective at normalizing temperatures from benthic species, resulting in a consistent record of temperature from species which shared the same habitat.

\subsubsection{Interpretation of Additional Trace Element Data}

Section 1.4.1 includes a review of the literature regarding use of trace metals other than $\mathrm{Mg}$ in reconstructing climatic and oceanographic changes from foraminifera. The details of $\mathrm{Mg} / \mathrm{Ca}, \mathrm{Al} / \mathrm{Ca}, \mathrm{Mn} / \mathrm{Ca}$ and $\mathrm{Sr} / \mathrm{Ca}$ have already been discussed in Chapter 3. The purpose of this section is to investigate whether any additional paleoenvironmental or paleoceanographic interpretations can be made from $\mathrm{Zn} / \mathrm{Ca}$ and $\mathrm{Ba} / \mathrm{Ca}$ trace element data. 

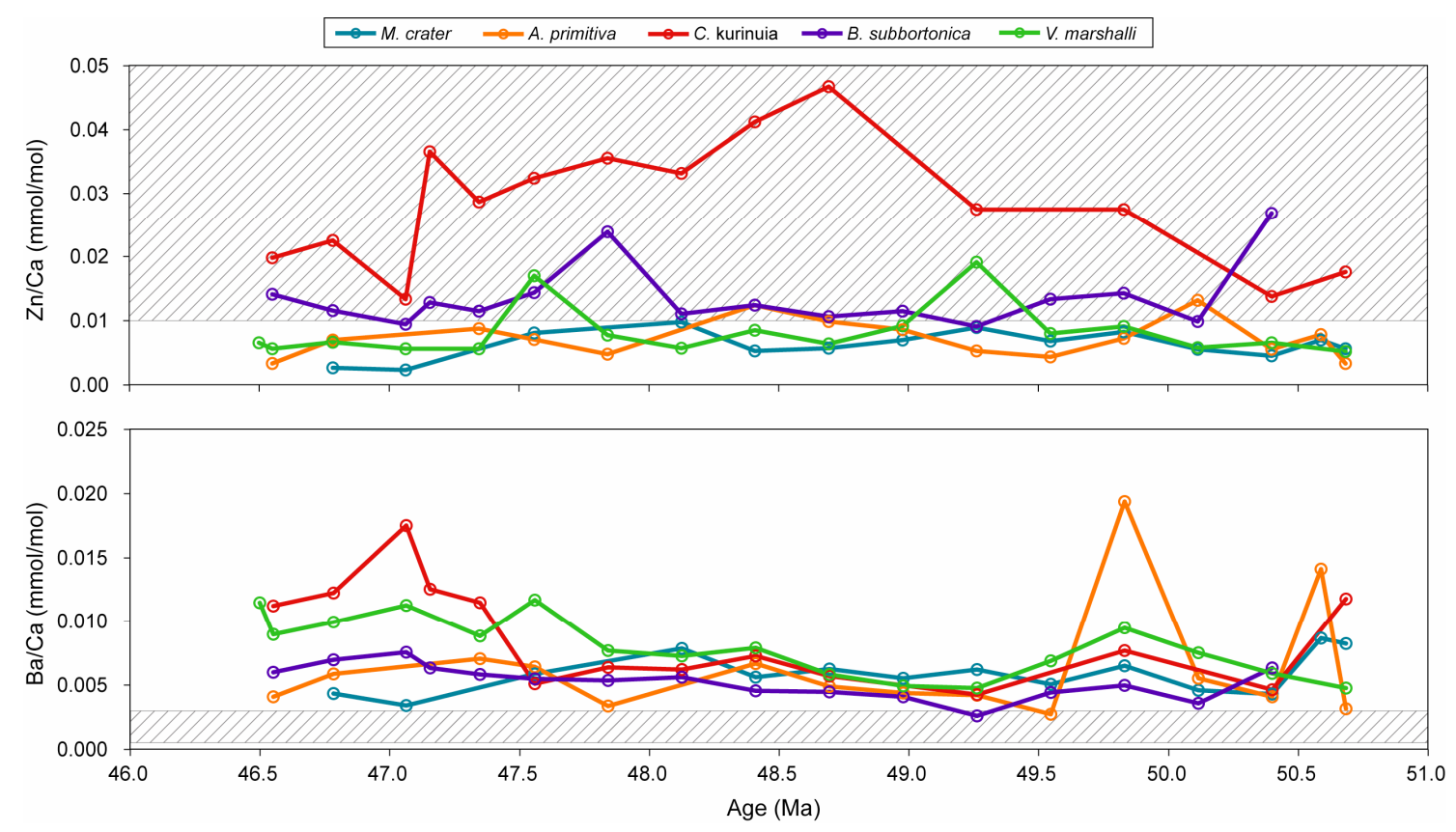

Figure 4.1. $\mathrm{Zn} / \mathrm{Ca}$ (a) and $\mathrm{Ba} / \mathrm{Ca}$ (b) data from 5 species of foraminifera from midWaipara. Boxes with diagonal bars indicate 'typical' values from modern foraminifera of $\mathrm{Zn} / \mathrm{Ca}$ (Lea, 2003b) and Ba/Ca (Rosenthal et al., 1999; Lea, 2003b; Marchitto et al., 2000, 2002).

Typical values for $\mathrm{Zn} / \mathrm{Ca}$ in modern foraminifera are in the range $0.010-0.075$ $\mathrm{mmol} / \mathrm{mol}$ (Lea, 2003b). Typical values from mid-Waipara are generally lower than the published values for modern foraminifera, in the range $0.005-0.012 \mathrm{mmol} / \mathrm{mol}$, with the exception of $C$. kurinuia, which has $\mathrm{Zn} / \mathrm{Ca}$ of $0.013-0.047 \mathrm{mmol} / \mathrm{mol}$, and were relatively consistent within each sample (Figure 4.1). These lower $\mathrm{Zn} / \mathrm{Ca}$ ratios could perhaps reflect a difference in the nutrient content and biogeochemical cycling of $\mathrm{Zn}$ in the Eocene ocean. However, there is no clear correlation in $\mathrm{Zn} / \mathrm{Ca}$ ratios between the different species of foraminifera, and no apparent relationship with other paleoenvironmental indicators, and thus no clear interpretation can be made.

$\mathrm{Ba} / \mathrm{Ca}$ ratios in foraminifera from the modern ocean (Rosenthal et al., 1999; Lea, 2003b) and back to the last glacial maximum (Marchitto et al., 2000, 2002) are typically found to be in the range $0.5-3.0 \mu \mathrm{mol} / \mathrm{mol}$. In the mid-Waipara samples, $\mathrm{Ba} / \mathrm{Ca}$ ratios were typically in the range $3-19 \mu \mathrm{mol} / \mathrm{mol}$ (Figure 4.1), which is considerably higher than the published values above. $\mathrm{Ba} / \mathrm{Ca}$ ratios were relatively consistent between species, particularly during the middle part of the record (Figure 4.1) No significant trends were observed between $\mathrm{Ba} / \mathrm{Ca}$ ratios from different species over the record, and the changes in $\mathrm{Ba} / \mathrm{Ca}$ do not appear to correlate with any other paleoenvironmental indicators used in this study. As there is significant potential for barite contamination, 
and studies of $\mathrm{Ba} / \mathrm{Ca}$ of foraminifera usually include considerable purification steps (Lea and Boyle, 1991, 1993) that were not included in the cleaning procedures utilized in this study, the $\mathrm{Ba} / \mathrm{Ca}$ ratios are interpreted to reflect variable diagenetic alteration that has overwhelmed any changes in the primary $\mathrm{Ba} / \mathrm{Ca}$ in these foraminifera.

\subsubsection{LA-ICP-MS Cleaning Procedures}

The laser ablation method has been shown to be effective at extracting reliable $\mathrm{Mg} / \mathrm{Ca}$ data, even where foraminiferal test preservation is variable, by identifying and excluding zones of enriched trace element compositions that represent contaminant phases such as diagenetic overgrowths and infilling sediments. Such phases have been shown to significantly alter $\mathrm{Mg} / \mathrm{Ca}$ ratios (Katz, 1973; Pena et al., 2005). Studies using solution ICP-MS analyses generally include comprehensive cleaning procedures prior to analysis, such as mechanical crushing and rinsing to remove adhering and infilling detrital sediments, oxidative cleaning to remove organic material, reductive cleaning to remove metal oxide coatings, and weak-acid leaching steps to remove adsorbed contaminants and surface layers of secondary calcite (e.g. Boyle and Keigwin, 1985; Barker et al., 2003), which have shown to be effective in reducing the input of $\mathrm{Mg}$ from contaminant phases (Pena et al., 2005).

LA-ICP-MS involves comparatively fast sample preparation, with straightforward cleaning procedures, as contaminant phases can be recognised and excluded from trace element depth profiles, which has been shown to by successful at excluding inputs from surface and infilling contaminant phases, and extracting reliable $\mathrm{Mg} / \mathrm{Ca}$ and other trace element data (Chapter 3). However for trace elements with very low concentrations $(<1-20 \mu \mathrm{mol} / \mathrm{mol})$ in foraminiferal calcite (e.g. Ba/Ca), contamination from extraneous contaminant phases appears to have overwhelmed primary element/Ca signatures (section 4.2.3), which may potentially limit the use of LA-ICP-MS for reconstructing other paleoceanographic information. It may be possible to develop similar cleaning processes to those used in solution analyses that could be applied to whole foraminifera shells, which could be tested by making LA-ICP-MS before and after cleaning, which may improve measurements of low concentration trace elements and yield additional paleoceanographic information. 


\subsubsection{Summary}

Some Eocene species have been shown to be less well suited to this type of analysis, generally yielding very short useable segments (e.g. G. wilcoxensis). The presence of surface decorations for some species consistently resulted in unusable trace element depth profiles (e.g. C. pre-parki). Based on their physical properties, typical trace element profiles, and the availability of specimens in mid-Waipara samples, the species M. crater, A. primitiva, C. kurinuia, B. subbortonica and V. marshalli were selected for the temperature-time record in Chapter 3.

Inter-species calibrations have been developed for the species analysed in this study by correcting for offsets from reference species in three well-characterised samples. These corrections have been effective in producing consistent temperature estimates from benthic foraminifera species over the mid-Waipara record.

$\mathrm{Zn} / \mathrm{Ca}$ and $\mathrm{Ba} / \mathrm{Ca}$ results from mid-Waipara foraminifera did not reveal any systematic variations, and no paleoceanographic interpretations were made from these data. In some cases, the primary signals from these low concentration elements may have been overwhelmed by secondary processes. Measurement of these trace elements by LA-ICP-MS in the future may require more comprehensive cleaning procedures, similar to those used in bulk methods.

\subsection{The Role of $\mathrm{CO}_{2}$ in the Greenhouse to Icehouse Transition}

Analysis of microlaminated sediments from deep sea cores collected in the Arctic Ocean has revealed an interval of up to $8 \mathrm{~m}$ thickness observed in many sediment cores, with alternating layers of siliciclastic sediments with planktonic microfossils and millimetre thick laminations comprising fossilised Azolla spores (Brinkhuis et al., 2006). Azolla phases have been recognized both within the Arctic basin and in all Nordic seas, and presence of the freshwater fern suggests that the sea surface waters were frequently dominated by fresh or brackish waters during an interval of at least 800 kyr, arising from a combination of the geographic restriction of the Arctic basin caused by arrangement of the northern hemisphere continents in the early Paleogene, and an intensified hydrological cycle pouring fresh waters into the basin, resulting in the stratification of the ocean and the episodic freshening of surface waters (Figure 4.2) (Brinkhuis et al., 2006). 


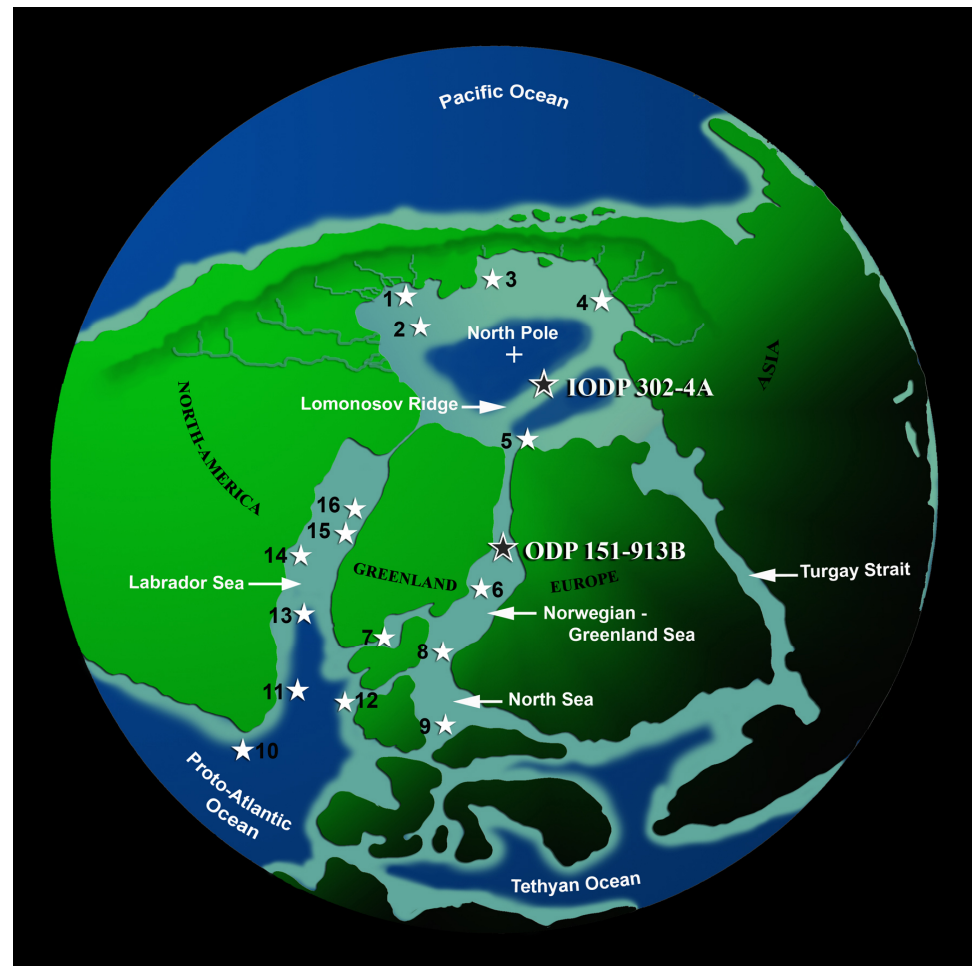

Figure 4.2. The configuration of the Northern Hemisphere continents in the early Eocene, showing the geographic restriction of the Arctic basin (from Brinkhuis et al., 2006). Numbers and stars indicate site localities in the Arctic basin and Nordic seas where "Azolla pulses" have been identified.

These thick, Azolla rich intervals suggest that large quantities of the Azolla fern grew and reproduced in situ in the Arctic Ocean during the middle Eocene (Brinkhuis et al., 2006). Cultivation experiments have shown that Azolla is one of the fastest growing plants on Earth, capable of doubling its biomass in two to three days and fixing large amounts of carbon (Wagner, 1997), and also shows a marked increase in productivity under elevated $\mathrm{pCO}_{2}$ conditions (Speelman et al., 2009). Burial of Azolla derived organic matter during this interval has been estimated to have a potential carbon storage capacity of $0.9-3.5 \times 10^{18} \mathrm{~g}$, equating to a potential reduction in $\mathrm{pCO}_{2}$ of $55-470 \mathrm{ppm}$ under Eocene conditions (Speelman et al., 2009).

The termination of the Azolla phase has been shown to occur within magnetochron C21r ( 48.3 Ma) at three sites from the Greenland and Norwegian seas (Eldrett et al., 2004). The Azolla phase occurs during a period of declining atmospheric $\mathrm{CO}_{2}$ (Pearson and Palmer, 2000; Pagani et al., 2005), and is coincident with an overall global cooling trend from ca. 48.5 Ma (Tripati et al., 2003, 2005; Zachos et al., 2008; this study) which is considered to be the beginning of the transition from the Early Eocene greenhouse towards the modern icehouse Earth. Thus, this interval of Azolla blooms in the Arctic 
has been recognized as a potential trigger for the transition from greenhouse to icehouse conditions (Brinkhuis et al., 2006; Speelman et al., 2009).

The timing of the inferred termination of the EECO from the reconstructed temperature record from at mid-Waipara $(\sim 48.5 \mathrm{Ma})$ is consistent with the termination of the EECO in other temperatures records (Tripati et al., 2003, 2005; Zachos et al., 2008), and is thus consistent with the hypothesis that blooms of the Azolla fern in Arctic Ocean were a factor in the termination of the EECO and the transition towards cooler global climate. 


\section{CONCLUSIONS}

\subsection{Conclusions}

A LA-ICP-MS study of the trace element chemistry of Eocene (51-46 Ma) planktonic and benthic foraminifera from mid-Waipara, southern New Zealand has shown that:

(1) LA-ICP-MS analytical techniques can be used to extract reliable $\mathrm{Mg} / \mathrm{Ca}$ sea temperature data from Eocene foraminifera, even where foraminifera test preservation is variable. This has been demonstrated by a strong agreement between reconstructed $\mathrm{Mg} / \mathrm{Ca}$ temperature data and data from two independent temperature proxies $\left(\delta^{18} \mathrm{O}\right.$ and $\mathrm{TEX}_{86}$ ). The ability of this technique to recover reliable paleotemperature information from less than ideally preserved specimens potentially makes many more samples available for studies of climate during the Paleogene, where pristine foraminiferal specimens are scarce.

(2) There is good agreement between the $\mathrm{Mg} / \mathrm{Ca}$ reconstructed sea temperatures and two independent temperature proxies $\left(\delta^{18} \mathrm{O}\right.$ and TEX $\left.{ }_{86}\right)$ in terms of sea surface and bottom water temperatures, which appears to indicate that the $\mathrm{Mg} / \mathrm{Ca}$-temperature calibrations based on modern species are applicable to Eocene foraminifera. Systematic differences in the incorporation of $\mathrm{Mg}$ have been identified in some Eocene species of foraminifera, which have been corrected for using inter-species calibrations based on 3 well-characterised mid-Waipara samples.

(3) During the EECO, sea surface temperatures at mid-Waipara (paleo-latitude $c a$. $54{ }^{\circ} \mathrm{S}$ ) were $28-30^{\circ} \mathrm{C}$, and bottom water temperatures were $18-20^{\circ} \mathrm{C}$. Temperatures were generally consistent for the period ca. 51-48.5 Ma with the exception of a $500 \mathrm{kyr}$ transient cooling of $3-4^{\circ} \mathrm{C}$ between $c a .50 .5$ and $50.0 \mathrm{Ma}$, and steadily declined from $c a$. 48.5 Ma until the end of the record at $46.5 \mathrm{Ma}$. A net cooling of $c a .6^{\circ} \mathrm{C}$ is observed over the entire mid-Waipara record.

(4) Reconstructed $\mathrm{Mg} / \mathrm{Ca}$ temperatures from the planktonic species $\mathrm{M}$. crater show excellent agreement with $\mathrm{TEX}_{86}$ temperatures, which provides constraints on estimates of the $\mathrm{Mg} / \mathrm{Ca}$ ratio of Eocene seawater. The value of seawater $\mathrm{Mg} / \mathrm{Ca}$ depends on the $\mathrm{TEX}_{86}$ temperature calibration used, but is in the range $2.24-3.35 \mathrm{mmol} / \mathrm{mol}$. Lower estimates of seawater $\mathrm{Mg} / \mathrm{Ca}$ increase reconstructed temperatures to levels that seem 
implausibly high in comparison to temperatures from $\mathrm{TEX}_{86}$. This range of estimates is consistent with constraints from other studies.

(5) Comparison between temperatures from $\mathrm{Mg} / \mathrm{Ca}$ and oxygen isotopes implies that seawater $\delta^{18} \mathrm{O}$ changed significantly over the mid-Waipara record. While the oxygen isotope signal has probably been disturbed to some extent by diagenesis, the $\delta^{18} \mathrm{O}_{\mathrm{sw}}$ record provides evidence for the presence of ice sheets on Antarctica during the Early Eocene greenhouse, potentially of $20 \%$ - $40 \%$ of the full size of the Antarctic ice sheets in the Pleistocene.

(6) The termination of the EECO and the beginning of the transition from greenhouse to icehouse conditions occurred at ca. $48.5 \mathrm{Ma}$, which is consistent with other paleoclimate records, and supports the hypothesis that the cooling from $48.5 \mathrm{Ma}$ may have been triggered by the draw down of $\mathrm{CO}_{2}$ by large quantities of Azolla growing in freshened surface waters in the Arctic Ocean.

\subsection{Suggestions for future work}

(1) A high priority for future work would be to confirm the paleoclimate interpretations made in this thesis by making LA-ICP-MS analyses of foraminifera from other sections from around New Zealand from the same time period e.g. Hampden Beach (Canterbury Basin), Tawanui (East Coast Basin). These could be used to determine whether the climate events identified in the mid-Waipara record were localised effects or were indeed large-scale climate events. Paleogene sediments are exposed at number localities around New Zealand, and samples from many of these have already been collected and curated by GNS Science. Additionally, a number of sediment cores that have been collected from around New Zealand as part of international drilling programs contain foraminifera from the Paleogene, which could potentially be utilised in future studies.

(2) The mid-Waipara samples used in the geochemical analyses of Hollis et al. (2009) and this study are a subset of a larger collection held by GNS Science, which could be used to produce a higher resolution climate record. Additionally, a portion of the mid-Waipara section could be resampled at a much higher resolution, and could potentially be used to reconstruct climate over orbital timescales (e.g. Burgess et al., 2008). 
(3) Multiproxy records have been essential in producing convincing, robust paleoclimate records, and thus future work should incorporate additional proxies where possible. Additional high resolution multiproxy records would help to resolve issues identified in this thesis, such as whether or not continental ice volume played a part in $\delta^{18} \mathrm{O}$ variations, and constraining the timing and magnitude of climate events. In the future, $\mathrm{Mg} / \mathrm{Ca}$ and $\delta^{18} \mathrm{O}$ analyses could be made on the same individuals, which might help to elucidate the links between diagenesis and $\delta^{18} \mathrm{O}$, and provide a more robust $\delta^{18} \mathrm{O}$ record. Diagenetic effects on the existing mid-Waipara $\delta^{18} \mathrm{O}$ record will have been exacerbated by the fact that each data point represents a single analysis from a single individual (Hollis et al., 2009). Thus, in the future, $\delta^{18} \mathrm{O}$ analyses would preferably be made for each specimen used for $\mathrm{Mg} / \mathrm{Ca}$. Trace element profiles could be used in combination with $\delta^{18} \mathrm{O}$ to identify and screen foraminifera that are likely to have disturbed trace element and isotopic compositions.

(4) Robust multiproxy temperature records could be used to further constrain changes in seawater $\mathrm{Mg} / \mathrm{Ca}$ over time by comparison between $\mathrm{Mg} / \mathrm{Ca}$ temperatures and those derived from independent temperature proxies. If Eocene seawater $\mathrm{Mg} / \mathrm{Ca}$ could be more tightly constrained, uncertainties in $\mathrm{Mg} / \mathrm{Ca}$ temperature reconstructions could be significantly reduced.

(5) The calibrations from modern foraminifera used in this thesis appear to be applicable to Eocene foraminifera, and this study has shown that temperature information can be extracted using laser ablation ICP-MS depth profiles even where foraminifera preservation is variable. Thus, a similar approach could be applied to even older (e.g. Cretaceous) specimens found at sedimentary sections around New Zealand (e.g. Marlborough) or elsewhere. By combining samples from various sedimentary sections, it would be possible to produce a low-resolution $\mathrm{Mg} / \mathrm{Ca}$-temperature record stretching from the present day back to the Cretaceous (making certain assumptions regarding the $\mathrm{Mg} / \mathrm{Ca}$ of seawater).

(6) Polished cross sections of foraminifera could be used map the distribution of trace elements in these foraminifera electron probe microanalysis (EPMA), which could be used to investigate how contaminant phases are incorporated into the tests of these variably preserved foraminifera e.g. whether Al-rich sediment or Mn-rich carbonate phases are present through the entire thickness of test walls occupying pore spaces. Manganese can be an activator of cathodoluminescence (CL) in calcite, and CL spectra 
collected simultaneously with x-ray element maps could potentially be a high sensitivity tracer of trace element distributions in foraminiferal calcite. 


\section{REFERENCES}

Alvarez, L. W., Alvarez, W., Asaro, F., Michel, H. V., 1980. Extraterrestrial cause for the Cretaceous-Tertiary extinction. Science 208, 1095-1108.

Anand, P., Elderfield, H., Conte, M. H., 2003. Calibration of $\mathrm{Mg} / \mathrm{Ca}$ thermometry in planktonic foraminifera from a sediment trap time series. Paleoceanography 18 , 1050 .

Andreasson, F. P., Schmitz, B., 1998. Tropical Atlantic seasonal dynamics in the Early Middle Eocene from stable oxygen and carbon isotope profiles of mollusk shells. Paleoceanography 13, 183-192.

Arrhenius, S., 1896. On the influence of carbonic acid in the air upon the temperature of the ground. Philosophical Magazine Series 5 41, 237 - 276.

Barker, P. F., 2001. Scotia Sea regional tectonic evolution: Implications for mantle flow and palaeocirculation. Earth-Science Reviews 55, 1-39.

Barker, S., Greaves, M., Elderfield, H., 2003. A study of cleaning procedures used for foraminiferal $\mathrm{Mg} / \mathrm{Ca}$ paleothermometry. Geochemistry Geophysics Geosystems 4,8407 .

Barker, S., Cacho, I., Benway, H., Tachikawa, K., 2005. Planktonic foraminiferal $\mathrm{Mg} / \mathrm{Ca}$ as a proxy for past oceanic temperatures: A methodological overview and data compilation for the Last Glacial Maximum. Quaternary Science Reviews 24, 821-834.

Barrera, E., Huber, B., 1993. Eocene to Oligocene oceanography and temperatures in the Antarctic Indian Ocean. In: The Antarctic paleoenvironment: A perspective on global change (Kennett J.P., Warnke D.A. eds.). American Geophysical Union Antarctic Research Series 49-65.

Bender, M. L., Lorens, R. B., Williams, D. F., 1975. Sodium, magnesium and strontium in the tests of planktonic foraminifera. Micropaleontology 21, 448-459.

Berggren, W. A., Kent, D. V., Swisher, C. C., Aubry, M., 1995. A revised Cenozoic geochronology and chronostratigraphy. In: Berggren, W. A., Kent, D. V., Aubry, M.-P., Hardenbol, J. (Editors), Geochronology, Time Scales and Global Stratigraphic Correlation. SEPM Special Publication 54, pp 129-212.

Berggren, W. A., Pearson, P. N., 2006. Taxonomy, biostratigraphy, and phylogeny of Eocene Morozovella. In: Atlas of Eocene Planktonic Foraminifera (Pearson, P.N., Olsson, R.K., Huber, B.T., Hemleben, C., Berggren, W.A. eds.) Cushman Foundation for Foraminiferal Research Special Publication 41, 343-376.

Berggren, W. A., Pearson, P. N., Huber, B., Wade, B. S., 2006. Taxonomy, biostratigraphy, and phylogeny of Eocene Acarinina. In: Atlas of Eocene Planktonic Foraminifera (Pearson, P.N., Olsson, R.K., Huber, B.T., Hemleben, 
C., Berggren, W.A. eds.) Cushman Foundation for Foraminiferal Research Special Publication 41, 257-326.

Bé, A., 1980. Gametogenic calcification in a spinose planktonic foraminifer, Globigerinoides sacculifer (Brady). Marine Micropaleontology 5, 283-310.

Bice, K. L., Birgel, D., Meyers, P. A., Dahl, K. A., Hinrichs, K., Norris, R. D., 2006. A multiple proxy and model study of Cretaceous upper ocean temperatures and atmospheric $\mathrm{CO}_{2}$ concentrations. Paleoceanography 21, 2002.

Bice, K. L., Marotzke, J., 2002. Could changing ocean circulation have destabilized methane hydrate at the Paleocene/Eocene boundary? Paleoceanography 17, 8-1.

Bijl, P. K., Schouten, S., Sluijs, A., Reichart, G., Zachos, J. C., Brinkhuis, H., 2009. Early Palaeogene temperature evolution of the southwest Pacific Ocean. Nature 461, 776-779.

Billups, K., Schrag, D., 2003. Application of benthic foraminiferal $\mathrm{Mg} / \mathrm{Ca}$ ratios to questions of Cenozoic climate change. Earth and Planetary Science Letters 209, 181-195.

Bishop, J. K. B., 1988. The barite-opal-organic carbon association in oceanic particulate matter. Nature 332, 341-343.

Boersma, A., Silva, I. P., Shackleton, N. J., 1987. Atlantic Eocene planktonic foraminiferal paleohydrographic indicators and stable isotope paleoceanography. Paleoceanography 2, 287-331.

Bohaty, S. M., Zachos, J. C., 2003. Significant Southern Ocean warming event in the late middle Eocene. Geology 31, 1017.

Boyle, E., Keigwin, L., 1985. Comparison of Atlantic and Pacific paleochemical records for the last 215,000 years: changes in deep ocean circulation and chemical inventories. Earth and Planetary Science Letters 76, 135-150.

Boyle, E. A., 1981. Cadmium, zinc, copper, and barium in foraminifera tests. Earth and Planetary Science Letters 53, 11-35.

Boyle, E. A., 1983. Manganese carbonate overgrowths on foraminifera tests. Geochimica et Cosmochimica Acta 47, 1815-1819.

Breecker, D. O., Sharp, Z. D., McFadden, L. D., 2010. Atmospheric $\mathrm{CO}_{2}$ concentrations during ancient greenhouse climates were similar to those predicted for A.D. 2100. Proceedings of the National Academy of Sciences 107, 576-580.

Brinkhuis, H., Schouten, S., Collinson, M. E., Sluijs, A., Damsté, J. S. S., Dickens, G. R., Huber, M., Cronin, T. M., Onodera, J., Takahashi, K., Bujak, J. P., Stein, R., van der Burgh, J., Eldrett, J. S., Harding, I. C., Lotter, A. F., Sangiorgi, F., Cittert, H. V. K., de Leeuw, J. W., Matthiessen, J., Backman, J., Moran, K., The Expedition 302 Scientists, 2006. Episodic fresh surface waters in the Eocene 
Arctic Ocean. Nature 441, 606-609.

Brown, S. J., Elderfield, H., 1996. Variations in $\mathrm{Mg} / \mathrm{Ca}$ and $\mathrm{Sr} / \mathrm{Ca}$ ratios of planktonic foraminifera caused by postdepositional dissolution: Evidence of shallow $\mathrm{Mg}$ dependent dissolution. Paleoceanography 11, 543-551.

Browne, G. H., Field, B. D., 1985. The lithostratigraphy of Late Cretaceous to early Pleistocene rocks of northern Canterbury, New Zealand. New Zealand Geological Survey Record 6, 63 p.

Browning, J. V., Miller, K. G., Sugarman, P. J., Kominz, M. A., McLaughlin, P. P., Kulpecz, A. A., Feigenson, M. D., 2008. 100 Myr record of sequences, sedimentary facies and sea level change from Ocean Drilling Program onshore coreholes, US Mid-Atlantic coastal plain. Basin Research 20, 227-248.

Burgess, C. E., Pearson, P. N., Lear, C. H., Morgans, H. E., Handley, L., Pancost, R. D., Schouten, S., 2008. Middle Eocene climate cyclicity in the southern Pacific: Implications for global ice volume. Geology 36, 651-654.

Cerling, T., 1991. Carbon dioxide in the atmosphere: evidence from Cenozoic and Mesozoic paleosols. American Journal of Science 291, 377-400.

Chamberlin, T. C., 1899. An attempt to frame a working hypothesis of the cause of glacial periods on an atmospheric basis. The Journal of Geology 7, 545-584.

Chan, L., 1977. On the barium data from the Atlantic GEOSECS expedition. Deep Sea Research Part II: Topical Studies in Oceanography 24, 613-649.

Clarke, F. W., Wheeler, W. C., 1922. The inorganic constituents of marine invertebrates. U.S. Geological Survey Professional Paper 124.

Coggon, R. M., Teagle, D. A. H., Smith-Duque, C. E., Alt, J. C., Cooper, M. J., 2010. Reconstructing past seawater $\mathrm{Mg} / \mathrm{Ca}$ and $\mathrm{Sr} / \mathrm{Ca}$ from mid-ocean ridge flank calcium carbonate veins. Science 327, 1114-1117.

Cooper, R. A., 2004. New Zealand Geological Timescale 2004/2 wallchart. Institute of Geological \& Nuclear Sciences information series 64.

Coxall, H. K., Wilson, P. A., Palike, H., Lear, C. H., Backman, J., 2005. Rapid stepwise onset of Antarctic glaciation and deeper calcite compensation in the Pacific Ocean. Nature 433, 53-57.

Cramer, B. S., Toggweiler, J. R., Wright, J. D., Katz, M. E., Miller, K. G., 2009. Ocean overturning since the Late Cretaceous: Inferences from a new benthic foraminiferal isotope compilation. Paleoceanography 24, PA4216.

Crowley, T. J., 1998. Significance of tectonic boundary conditions for paleoclimate simulations. In: Crowley T.J., Burke K.C. (eds.), Tectonic boundary conditions for climate reconstructions. New York Oxford University Press, pp 3-17. 
Crowley, T. J., North, G. R., 1991. Paleoclimatology, Oxford University Press, 339p.

Crowley, T. J., Zachos, J. C., 2000. Comparison of zonal temperature profiles for past warm time periods. In: Warm Climates in Earth History. B.T. Huber, K.G. MacLeod, S.L. Wing (eds.) 50 - 77.

D'Hondt, S., Arthur, M. A., 1996. Late Cretaceous oceans and the Cool Tropic Paradox. Science 271, 1838-1841.

Dansgaard, W., White, J. W. C., Johnsen, S. J., 1989. The abrupt termination of the Younger Dryas climate event. Nature 339, 532-534.

DeConto, R. M., Pollard, D., 2003. Rapid Cenozoic glaciation of Antarctica induced by declining atmospheric $\mathrm{CO}_{2}$. Nature 421, 245-249.

DeConto, R. M., Pollard, D., Wilson, P. A., Palike, H., Lear, C. H., Pagani, M., 2008. Thresholds for Cenozoic bipolar glaciation. Nature 455, 652-656.

Dekens, P. S., Lea, D. W., Pak, D. K., Spero, H. J., 2002. Core top calibration of Mg/Ca in tropical foraminifera: Refining paleotemperature estimation. Geochemistry, Geophysics, Geosystems 3, 1022.

Delaney, M. L., Bé, A., Boyle, E. A., 1985. Li, Sr, Mg, and $\mathrm{Na}$ in foraminiferal calcite shells from laboratory culture, sediment traps, and sediment cores. Geochimica et Cosmochimica Acta 49, 1327-1341.

Delaney, M. L., Boyle, E. A., 1986. Lithium in foraminiferal shells: Implications for high-temperature hydrothermal circulation fluxes and oceanic crustal generation rates. Earth and Planetary Science Letters 80, 91-105.

Demicco, R. V., Lowenstein, T. K., Hardie, L. A., 2003. Atmospheric $\mathrm{pCO}_{2}$ since 60 Ma from records of seawater $\mathrm{pH}$, calcium, and primary carbonate mineralogy. Geology 31, 793-796.

Dickens, G. R., O'Neil, J. R., Rea, D. K., Owen, R. M., 1995. Dissociation of oceanic methane hydrate as a cause of the carbon isotope excursion at the end of the Paleocene. Paleoceanography 10, 965-971.

Dickson, J. A. D., 2002. Fossil echinoderms as monitor of the $\mathrm{Mg} / \mathrm{Ca}$ ratio of Phanerozoic oceans. Science 298, 1222-1224.

Diester-Haass, L., Zahn, R., 1996. Eocene-Oligocene transition in the Southern Ocean: History of water mass circulation and biological productivity. Geology 24, 163.

Eggins, S., De Deckker, P., Marshall, J., 2003. Mg/Ca variation in planktonic foraminifera tests: Implications for reconstructing palaeo-seawater temperature and habitat migration. Earth and Planetary Science Letters 212, 291-306.

Eggins, S. M., Sadekov, A., De Deckker, P., 2004. Modulation and daily banding of $\mathrm{Mg} / \mathrm{Ca}$ in Orbulina universa tests by symbiont photosynthesis and respiration: A 
complication for seawater thermometry? Earth and Planetary Science Letters 225, 411-419.

Ehrmann, W. U., Mackensen, A., 1992. Sedimentological evidence for the formation of an East Antarctic ice sheet in Eocene/Oligocene time. Palaeogeography, Palaeoclimatology, Palaeoecology 93, 85-112.

Elderfield, H., Ganssen, G., 2000. Past temperature and $\delta^{18} \mathrm{O}$ of surface ocean waters inferred from foraminiferal $\mathrm{Mg} / \mathrm{Ca}$ ratios. Nature 405, 442-5.

Elderfield, H., Bertram, C. J., Erez, J., 1996. A biomineralization model for the incorporation of trace elements into foraminiferal calcium carbonate. Earth and Planetary Science Letters 142, 409-423.

Elderfield, H., Schultz, A., 1996. Mid-ocean ridge hydrothermal fluxes and the chemical composition of the ocean. Annual Review of Earth and Planetary Sciences 24, 191-224.

Elderfield, H., Yu, J., Anand, P., Kiefer, T., Nyland, B., 2006. Calibrations for benthic foraminiferal $\mathrm{Mg} / \mathrm{Ca}$ paleothermometry and the carbonate ion hypothesis. Earth and Planetary Science Letters 250, 633-649.

Elderfield, H., 2002. Climate change: Carbonate mysteries. Science 296, 1618-1621.

Eldrett, J. S., Harding, I. C., Firth, J. V., Roberts, A. P., 2004. Magnetostratigraphic calibration of Eocene-Oligocene dinoflagellate cyst biostratigraphy from the Norwegian-Greenland Sea. Marine Geology 204, 91-127.

Emiliani, C., 1955. Pleistocene temperatures. The Journal of Geology 63, 538-578.

Epstein, S., Buchsbaum, R., Lowenstam, H., Urey, H. C., 1951. Carbonate-water isotopic temperature scale. Geological Society of America Bulletin 62, 417-426.

Erez, J., Luz, B., 1983. Experimental paleotemperature equation for planktonic foraminifera. Geochimica et Cosmochimica Acta 47, 1025-1031.

Fletcher, B. J., Brentnall, S. J., Anderson, C. W., Berner, R. A., Beerling, D. J., 2008. Atmospheric carbon dioxide linked with Mesozoic and early Cenozoic climate change. Nature Geoscience 1, 43-48.

Forsyth, P. J., Barrell, D. J. A., Jongens, R., (Compilers), 2008. Geology of the Christchurch area. Institute of Geological \& Nuclear Sciences 1:250 000 geological map 16, 1 sheet $+67 \mathrm{p}$.

Gagan, M. K., Ayliffe, L. K., Beck, J. W., Cole, J. E., Druffel, E. R. M., Dunbar, R. B., Schrag, D. P., 2000. New views of tropical paleoclimates from corals. Quaternary Science Reviews 19, 45-64.

Graham, D. W., Bender, M. L., Williams, D. F., Keigwin Jr., L. D., 1982. Strontiumcalcium ratios in Cenozoic planktonic foraminifera. Geochimica et 
Cosmochimica Acta 46, 1281-1292.

Greenwood, D. R., Wing, S. L., 1995. Eocene continental climates and latitudinal temperature gradients. Geology 23, 1044.

Hall, J. M., Chan, L., 2004. Ba/Ca in benthic foraminifera: Thermocline and middepth circulation in the North Atlantic during the last glaciation. Paleoceanography 19, PA4018.

Haq, B., Hardenbol, J., Vail, P., 1987. Chronology of fluctuating sea levels since the Triassic. Science 235, 1156-1167.

Hardie, L. A., 1996. Secular variation in seawater chemistry: An explanation for the coupled secular variation in the mineralogies of marine limestones and potash evaporites over the past 600 Myr. Geology 24, 279-283.

Hayward, B. W., 1986. A guide to paleoenvironmental assessment using New Zealand Cenozoic foraminiferal faunas. New Zealand Geological Survey Repository on Paleontology 109, 1-73.

Hayward, B. W., Buzas, M. A., 1979. Taxonomy and paleoecology of early Miocene benthic foraminifera of northern New Zealand and the north Tasman Sea. Smithsonian contributions to Paleobiology 36, 154.

Hayward, B. W., Hollis, C. J., Grenfell, H. R., 1997. Recent Elphidiidae (Foraminiferida) of the South-west Pacific and fossil Elphidiidae of New Zealand. Institute of Geological \& Nuclear Sciences Monograph 16.

Head, J. J., Bloch, J. I., Hastings, A. K., Bourque, J. R., Cadena, E. A., Herrera, F. A., Polly, P. D., Jaramillo, C. A., 2009. Giant boid snake from the Palaeocene neotropics reveals hotter past equatorial temperatures. Nature 457, 715-717.

Hecht, A. D., Eslinger, E. V., Garmon, L. B., 1975. Experimental studies on the dissolution of planktonic foraminifera. Dissolution of Deep-Sea Carbonates, Cushman Foundation for Foraminiferal Research pp. 56-69.

Hemming, N., Hanson, G., 1992. Boron isotopic composition and concentration in modern marine carbonates. Geochimica et Cosmochimica Acta 56, 537-543.

Hollis, C. J., Handley, L., Crouch, E. M., Morgans, H. E., Baker, J. A., Creech, J., Collins, K. S., Gibbs, S. J., Huber, M., Schouten, S., Zachos, J. C., Pancost, R. D., 2009. Tropical sea temperatures in the high-latitude South Pacific during the Eocene. Geology 37, 99-102.

Hopmans, E. C., Weijers, J. W., Schefuß, E., Herfort, L., Sinninghe Damsté, J. S., Schouten, S., 2004. A novel proxy for terrestrial organic matter in sediments based on branched and isoprenoid tetraether lipids. Earth and Planetary Science Letters 224, 107-116.

Horita, J., Zimmermann, H., Holland, H. D., 2002. Chemical evolution of seawater 
during the Phanerozoic: Implications from the record of marine evaporites. Geochimica et Cosmochimica Acta 66, 3733-3756.

Huber, B. T., Hodell, D. A., Hamilton, C. P., 1995. Middle-Late Cretaceous climate of the southern high latitudes: Stable isotopic evidence for minimal equator-to-pole thermal gradients. Geological Society of America Bulletin 107, 1164-1191.

Huber, M., Brinkhuis, H., Stickley, C. E., Döös, K., Sluijs, A., Warnaar, J., Schellenberg, S. A., Williams, G. L., 2004. Eocene circulation of the Southern Ocean: Was Antarctica kept warm by subtropical waters? Paleoceanography 19, 4026.

Huber, M., Sloan, L. C., 2001. Heat transport, deep waters, and thermal gradients: Coupled simulation of an Eocene Greenhouse Climate. Geophysical Research Letters 28, 3481-3484.

Jenkins, D. G., 1971. New Zealand Cenozoic planktonic foraminifera. New Zealand Geological Survey Bulletin 70, 173 p.

Jenkyns, H. C., Forster, A., Schouten, S., Sinninghe Damsté, J. S., 2004. High temperatures in the Late Cretaceous Arctic Ocean. Nature 432, 888-892.

Jochum, K. P., Stoll, B., 2008. Reference materials for elemental and isotopic analyses by LA-(MC)-ICP-MS: successes and outstanding needs. In: Laser Ablation ICPMS in the Earth Sciences: Current practices and outstanding issues (P. Sylvester, ed.) Mineralogy Association of Canada, 147 - 168.

Katz, A., 1973. The interaction of magnesium with calcite during crystal growth at 25$90^{\circ} \mathrm{C}$ and one atmosphere. Geochimica et Cosmochimica Acta 37, 1563-1578, IN3, 1579-1586.

Kennett, J. P., 1977. Cenozoic evolution of Antarctic glaciation, the circum-Antarctic Ocean, and their impact on global paleoceanography. Journal of Geophysical Research 82, 3843-3860.

Kim, J., Meer, J. V. D., Schouten, S., Helmke, P., Willmott, V., Sangiorgi, F., Koç, N., Hopmans, E. C., Damsté, J. S. S., 2010. New indices and calibrations derived from the distribution of crenarchaeal isoprenoid tetraether lipids: Implications for past sea surface temperature reconstructions. Geochimica et Cosmochimica Acta 74, 4639 - 4654.

Kim, J., Schouten, S., Hopmans, E. C., Donner, B., Sinninghe Damsté, J. S., 2008. Global sediment core-top calibration of the $\mathrm{TEX}_{86}$ paleothermometer in the ocean. Geochimica et Cosmochimica Acta 72, 1154-1173.

King, P. R., Naish, T. R., Browne, G. H., Field, B. D., Edbrooke, S. W., 1999. Cretaceous to Recent sedimentary patterns in New Zealand. Institute of Geological \& Nuclear Sciences folio series 1, 35 p.

Kobashi, T., Grossman, E. L., Yancey, T. E., Dockery, D. T., 2001. Reevaluation of 
conflicting Eocene tropical temperature estimates: Molluskan oxygen isotope evidence for warm low latitudes. Geology 29, 983.

Kolodny, Y., Raab, M., 1988. Oxygen isotopes in phosphatic fish remains from Israel: Paleothermometry of tropical Cretaceous and Tertiary shelf waters. Palaeogeography, Palaeoclimatology, Palaeoecology 64, 59-67.

Kominz, M. A., Browning, J. V., Miller, K. G., Sugarman, P. J., Mizintseva, S., Scotese, C. R., 2008. Late Cretaceous to Miocene sea-level estimates from the New Jersey and Delaware coastal plain coreholes: An error analysis. Basin Research 20, 211-226.

Kominz, M. A., Miller, K. G., Browning, J. V., 1998. Long-term and short-term global Cenozoic sea-level estimates. Geology 26, 311.

Lawver, L. A., Gahagan, L. M., 1998. Opening of Drake Passage and its impact on Cenozoic ocean circulation. In: Tectonic boundary conditions for climate reconstructions. Crowley, T.J., and Burke, K. (eds.) Oxford Monographs on Geology and Geophysics 39.

Lawver, L. A., Gahagan, L. M., 2003. Evolution of Cenozoic seaways in the circumAntarctic region. Palaeogeography, Palaeoclimatology, Palaeoecology 198, 1137.

Lea, D., Boyle, E., 1989. Barium content of benthic foraminifera controlled by bottomwater composition. Nature 338, 751-753.

Lea, D. W., 2003a. Elemental and isotopic proxies of past ocean temperatures. Treatise on Geochemistry 6, 365-390.

Lea, D., 2003b. Trace elements in foraminiferal calcite. In: Modern Foraminifera (B. K. Sen Gupta, ed.) 259-277.

Lea, D. W., Boyle, E. A., 1991. Barium in planktonic foraminifera. Geochimica et Cosmochimica Acta 55, 3321-3331.

Lea, D. W., 1993. Constraints on the alkalinity and circulation of glacial circumpolar deep water from benthic foraminiferal barium. Global Biogeochemical Cycles 7, 695-710.

Lea, D. W., 1995. A trace metal perspective on the evolution of Antarctic circumpolar deep water chemistry. Paleoceanography 10, 733-747.

Lea, D. W., Boyle, E. A., 1993. Determination of carbonate-bound barium in foraminifera and corals by isotope dilution plasma-mass spectrometry. Chemical Geology 103, 73-84.

Lea, D. W., Mashiotta, T. A., Spero, H. J., 1999. Controls on magnesium and strontium uptake in planktonic foraminifera determined by live culturing. Geochimica et Cosmochimica Acta 63, 2369-2379. 
Lear, C. H., Rosenthal, Y., Slowey, N., 2002. Benthic foraminiferal Mg/Capaleothermometry: A revised core-top calibration. Geochimica et Cosmochimica Acta 66, 3375-3387.

Lear, C. H., Elderfield, H., Wilson, P. A., 2000. Cenozoic deep-sea temperatures and global ice volumes from $\mathrm{Mg} / \mathrm{Ca}$ in benthic foraminiferal calcite. Science 287, 269-272.

Lear, C., Elderfield, H., Wilson, P., 2003. A Cenozoic seawater Sr/Ca record from benthic foraminiferal calcite and its application in determining global weathering fluxes. Earth and Planetary Science Letters 208, 69-84.

Lear, C. H., Bailey, T. R., Pearson, P. N., Coxall, H. K., Rosenthal, Y., 2008. Cooling and ice growth across the Eocene-Oligocene transition. Geology 36, 251-254.

Liu, Z., Pagani, M., Zinniker, D., DeConto, R., Huber, M., Brinkhuis, H., Shah, S. R., Leckie, R. M., Pearson, A., 2009. Global cooling during the Eocene-Oligocene climate transition. Science 323, 1187-1190.

Livermore, R., Nankivell, A., Eagles, G., Morris, P., 2005. Paleogene opening of Drake Passage. Earth and Planetary Science Letters 236, 459-470.

Lorens, R. B., Williams, D. F., Bender, M. L., 1977. The early nonstructural chemical diagenesis of foraminiferal calcite. Journal of Sedimentary Research 47, 16021609.

Lourens, L. J., Sluijs, A., Kroon, D., Zachos, J. C., Thomas, E., Röhl, U., Bowles, J., Raffi, I., 2005. Astronomical pacing of late Palaeocene to early Eocene global warming events. Nature 435, 1083-1087.

Lowenstein, T. K., Demicco, R. V., 2006. Elevated Eocene atmospheric $\mathrm{CO}_{2}$ and its subsequent decline. Science 313, 1928.

Lowenstein, T. K., Hardie, L. A., Timofeeff, M. N., Demicco, R. V., 2003. Secular variation in seawater chemistry and the origin of calcium chloride basinal brines. Geology 31, 857.

Lowenstein, T. K., Timofeeff, M. N., Brennan, S. T., Hardie, L. A., Demicco, R. V., 2001. Oscillations in Phanerozoic seawater chemistry: Evidence from fluid inclusions. Science 294, 1086-1088.

Marchitto, T. M., Curry, W. B., Oppo, D. W., 2000. Zinc concentrations in benthic foraminifera reflect seawater chemistry. Paleoceanography 15, 299-306.

Marchitto, T. M., Oppo, D. W., Curry, W. B., 2002. Paired benthic foraminiferal Cd/Ca and $\mathrm{Zn} / \mathrm{Ca}$ evidence for a greatly increased presence of Southern Ocean Water in the glacial North Atlantic. Paleoceanography 17, 10-1.

Markwick, P., 1998. Fossil crocodilians as indicators of Late Cretaceous and Cenozoic 
climates: Implications for using palaeontological data in reconstructing palaeoclimate. Palaeogeography, Palaeoclimatology, Palaeoecology 137, 205271.

Marr, J., 2009. Ecological, oceanographic and temperature controls on the incorporation of trace elements into Globigerina bulloides and Globoconella inflata in the Southwest Pacific Ocean (M.Sc. thesis). Victoria University of Wellington.

Martin, P. A., Lea, D. W., 1998. Comparison of water mass changes in the deep tropical Atlantic derived from $\mathrm{Cd} / \mathrm{Ca}$ and carbon isotope records: Implications for changing Ba composition of deep Atlantic water masses. Paleoceanography 13, $572-585$.

Mashiotta, T. A., Lea, D. W., Spero, H. J., 1999. Glacial-interglacial changes in Subantarctic sea surface temperature and $\delta^{18} \mathrm{O}$-water using foraminiferal $\mathrm{Mg}$. Earth and Planetary Science Letters 170, 417-432.

Merico, A., Tyrrell, T., Wilson, P. A., 2008. Eocene/Oligocene ocean de-acidification linked to Antarctic glaciation by sea-level fall. Nature 452, 979-982.

Miller, K. G., Fairbanks, R. G., Mountain, G. S., 1987. Tertiary oxygen isotope synthesis, sea level history, and continental margin erosion. Paleoceanography 2 , $1-19$.

Miller, K. G., Kominz, M. A., Browning, J. V., Wright, J. D., Mountain, G. S., Katz, M. E., Sugarman, P. J., Cramer, B. S., Christie-Blick, N., Pekar, S. F., 2005b. The Phanerozoic record of global sea-level change. Science 310, 1293-1298.

Miller, K. G., Sugarman, P. J., Browning, J. V., Kominz, M. A., Hernández, J. C., Olsson, R. K., Wright, J. D., Feigenson, M. D., van Sickel, W., 2003. Late Cretaceous chronology of large, rapid sea-level changes: Glacioeustasy during the greenhouse world. Geology 31, 585.

Miller, K. G., Wright, J. D., Browning, J. V., 2005a. Visions of ice sheets in a greenhouse world. Marine Geology 217, 215-231.

Miller, K. G., Wright, J. D., Fairbanks, R. G., 1991. Unlocking the ice house: Oligocene-Miocene oxygen isotopes, eustasy, and margin erosion. Journal of Geophysical Research 96, 6829-6848.

Moran, K., Backman, J., Brinkhuis, H., Clemens, S. C., Cronin, T., Dickens, G. R., Eynaud, F., Gattacceca, J., Jakobsson, M., Jordan, R. W., Kaminski, M., King, J., Koc, N., Krylov, A., Martinez, N., Matthiessen, J., McInroy, D., Moore, T. C., Onodera, J., O'Regan, M., Pälike, H., Rea, B., Rio, D., Sakamoto, T., Smith, D. C., Stein, R., St John, K., Suto, I., Suzuki, N., Takahashi, K., Watanabe, M., Yamamoto, M., Farrell, J., Frank, M., Kubik, P., Jokat, W., Kristoffersen, Y., 2006. The Cenozoic palaeoenvironment of the Arctic Ocean. Nature 441, 601605.

Morgans, H. E. G., Jones, C. M., Crouch, E. M., Field, B. D., Hollis, C. J., Raine, J. I., 
Strong, C. P., Wilson, G. J., 2005. Upper Cretaceous to Eocene stratigraphy and sample collections, Mid-Waipara River section, North Canterbury. Institute of Geological and Nuclear Sciences science report 2003/08, 107p.

van Morkhoven, F. C. P. M., Berggren, W. A., Edwards, A. S., 1986. Cenozoic cosmopolitan deep-water benthic foraminifera. Bulletin Centres Recherches Exploration-Production. Elf Aquitaine, Memoire 4 11, pp. 68-70.

Müller, R. D., Bender, M., Gaina, C., Steinberger, B., Heine, C., 2008. Long-term sealevel fluctuations driven by ocean basin dynamics. Science 319, 1357-1362.

Murray, J. W., 1976. A method of determining proximity of marginal seas to an ocean. Marine Geology 22, 103-119.

Nicolo, M. J., Dickens, G. R., Hollis, C. J., Zachos, J. C., 2007. Multiple early Eocene hyperthermals: Their sedimentary expression on the New Zealand continental margin and in the deep sea. Geology 35, 699-702.

Nielsen, S. G., Mar-Gerrison, S., Gannoun, A., LaRowe, D., Klemm, V., Halliday, A. N., Burton, K. W., Hein, J. R., 2009. Thallium isotope evidence for a permanent increase in marine organic carbon export in the early Eocene. Earth and Planetary Science Letters 278, 297-307.

Norris, R. D., Bice, K. L., Magno, E. A., Wilson, P. A., 2002. Jiggling the tropical thermostat in the Cretaceous hothouse. Geology 30, 299.

Nürnberg, D., 1995. Magnesium in tests of Neogloboquadrina pachyderma sinistral from high northern and southern latitudes. Journal of Foraminiferal Research 25, 350-368.

Nürnberg, D., Bijma, J., Hemleben, C., 1996. Assessing the reliability of magnesium in foraminiferal calcite as a proxy for water mass temperatures. Geochimica et Cosmochimica Acta 60, 803-814.

Oomori, T., Kaneshima, H., Maezato, Y., Kitano, Y., 1987. Distribution coefficient of $\mathrm{Mg}^{2+}$ ions between calcite and solution at $10-50^{\circ} \mathrm{C}$. Marine Chemistry 20, 327336.

Pagani, M., Zachos, J. C., Freeman, K. H., Tipple, B., Bohaty, S., 2005. Marked decline in atmospheric carbon dioxide concentrations during the Paleogene. Science 309, 600-603.

Pearce, N. J., Perkins, W. T., Westgate, J. A., Gorton, M. P., Jackson, S. E., Neal, C. R., Chenery, S. P., 1997. A compilation of new and published major and trace element data for NIST SRM 610 and NIST SRM 612 glass reference materials. Geostandards and Geoanalytical Research 21, 115-144.

Pearson, P. N., van Dongen, B. E., Nicholas, C. J., Pancost, R. D., Schouten, S., Singano, J. M., Wade, B. S., 2007. Stable warm tropical climate through the Eocene Epoch. Geology 35, 211-214. 
Pearson, P. N., Olss, R. K., Huber, B. T., Hemleben, C., Coxall, H. K., 2006. Overview of Eocene planktonic foraminiferal taxonomy, paleoecology, phylogeny, and biostratigraphy. In Pearson, P.N., Olsson, R.K., Huber, B.T., Hemleben, C. and Berggren, W.A. (eds.), Atlas of Eocene Planktonic Foraminifera. Cushman Foundation Special Publication No. 41 11-28.

Pearson, P. N., Ditchfield, P. W., Singano, J., Harcourt-Brown, K. G., Nicholas, C. J., Olsson, R. K., Shackleton, N. J., Hall, M. A., 2001. Warm tropical sea surface temperatures in the Late Cretaceous and Eocene epochs. Nature 413, 481-487.

Pearson, P. N., Foster, G. L., Wade, B. S., 2009. Atmospheric carbon dioxide through the Eocene-Oligocene climate transition. Nature 461, 1110-1113.

Pearson, P. N., Palmer, M. R., 1999. Middle Eocene seawater pH and atmospheric carbon dioxide concentrations. Science 284, 1824-1826.

Pearson, P. N., Palmer, M. R., 2000. Atmospheric carbon dioxide concentrations over the past 60 million years. Nature 406, 695-699.

Pekar, S. F., DeConto, R. M., 2006. High-resolution ice-volume estimates for the early Miocene: Evidence for a dynamic ice sheet in Antarctica. Palaeogeography, Palaeoclimatology, Palaeoecology 231, 101 - 109.

Pekar, S. F., Hucks, A., Fuller, M., Li, S., 2005. Glacioeustatic changes in the early and middle Eocene (51-42 Ma): Shallow-water stratigraphy from ODP Leg 189 Site 1171 (South Tasman Rise) and deep-sea $\delta^{18} \mathrm{O}$ records. Geological Society of America Bulletin 117, 1081-1093.

Pena, L. D., Calvo, E., Cacho, I., Eggins, S., Pelejero, C., 2005. Identification and removal of Mn-Mg-rich contaminant phases on foraminiferal tests: Implications for $\mathrm{Mg} / \mathrm{Ca}$ past temperature reconstructions. Geochemistry Geophysics Geosystems 6, Q09P02.

Petit, J. R., Jouzel, J., Raynaud, D., Barkov, N. I., Barnola, J., Basile, I., Bender, M., Chappellaz, J., Davis, M., Delaygue, G., Delmotte, M., Kotlyakov, V. M., Legrand, M., Lipenkov, V. Y., Lorius, C., Pepin, L., Ritz, C., Saltzman, E., Stievenard, M., 1999. Climate and atmospheric history of the past 420,000 years from the Vostok ice core, Antarctica. Nature 399, 429-436.

Pingitore, N. E., Eastman, M. P., Sandidge, M., Oden, K., Freiha, B., 1988. The coprecipitation of manganese(II) with calcite: an experimental study. Marine Chemistry 25, 107-120.

Pirrie, D., Marshall, J. D., 1990. High-paleolatitude Late Cretaceous paleotemperatures: New data from James Ross Island, Antarctica. Geology 18, 31-34.

Poore, R., Matthews, R., 1984. Oxygen isotope ranking of late Eocene and Oligocene planktonic foraminifers: Implications for Oligocene sea-surface temperatures and global ice-volume. Marine Micropaleontology 9, 111-134. 
Poulsen, C. J., Barron, E. J., Peterson, W. H., Wilson, P. A., 1999. A reinterpretation of mid-Cretaceous shallow marine temperatures through model-data comparison. Paleoceanography 14, 679-697.

Quilléveré, F., Norris, R. D., Moussa, I., Berggren, W. A., 2001. Role of photosymbiosis and biogeography in the diversification of early Paleogene acarininids (planktonic foraminifera). Paleobiology 27, 311-326.

Reichart, G., Jorissen, F., Anschutz, P., Mason, P. R., 2003. Single foraminiferal test chemistry records the marine environment. Geology 31, 355-358.

Retallack, G. J., 2001. A 300-million-year record of atmospheric carbon dioxide from fossil plant cuticles. Nature 411, 287-290.

Rosenthal, Y., Lohmann, G. P., Lohmann, K. C., Sherrell, R. M., 2000. Incorporation and preservation of $\mathrm{Mg}$ in Globigerinoides sacculifer: Implications for reconstructing the temperature and ${ }^{18} \mathrm{O} /{ }^{16} \mathrm{O}$ of seawater. Paleoceanography 15 , $135-145$.

Rosenthal, Y., Boyle, E. A., 1993. Factors controlling the fluoride content of planktonic foraminifera: An evaluation of its paleoceanographic applicability. Geochimica et Cosmochimica Acta 57, 335-346.

Rosenthal, Y., Boyle, E. A., Slowey, N., 1997. Temperature control on the incorporation of magnesium, strontium, fluorine, and cadmium into benthic foraminiferal shells from Little Bahama Bank: Prospects for thermocline paleoceanography. Geochimica et Cosmochimica Acta 61, 3633-3643.

Rosenthal, Y., Field, M. P., Sherrell, R. M., 1999. Precise determination of element/calcium ratios in calcareous samples using sector field inductively coupled plasma mass spectrometry. Analytical Chemistry 71, 3248-3253.

Rosenthal, Y., Lohmann, G. P., 2002. Accurate estimation of sea surface temperatures using dissolution-corrected calibrations for $\mathrm{Mg} / \mathrm{Ca}$ paleothermometry. Paleoceanography 17, 1044.

Royer, D. L., 2006. $\mathrm{CO}_{2}$-forced climate thresholds during the Phanerozoic. Geochimica et Cosmochimica Acta 70, 5665-5675.

Royer, D. L., Wing, S. L., Beerling, D. J., Jolley, D. W., Koch, P. L., Hickey, L. J., Berner, R. A., 2001. Paleobotanical Evidence for Near Present-Day Levels of Atmospheric $\mathrm{CO}_{2}$ During Part of the Tertiary. Science 292, 2310-2313.

Röhl, U., Bralower, T., Norris, R., Wefer, G., 2000. New chronology for the late Paleocene thermal maximum and its environmental implications. Geology 28, 927-930.

Röhl, U., Westerhold, T., Monechi, S., Thomas, E., Zachos, J. C., Donner, B., 2005. The third and final early Eocene thermal maximum: characteristics, timing, and 
mechanisms of the "X" event. Geological Society of America Annual Meeting Abstract 37, 264.

Röhl, U., Westerhold, T., Bralower, T. J., Zachos, J. C., 2007. On the duration of the Paleocene-Eocene thermal maximum (PETM). Geochemistry, Geophysics, Geosystems 8, Q12002.

Russell, A. D., Emerson, S., Nelson, B. K., Erez, J., Lea, D. W., 1994. Uranium in foraminiferal calcite as a recorder of seawater uranium concentrations. Geochimica et Cosmochimica Acta 58, 671-681.

Sadekov, A., Eggins, S. M., Deckker, P. D., Kroon, D., 2008. Uncertainties in seawater thermometry deriving from intratest and intertest $\mathrm{Mg} / \mathrm{Ca}$ variability in Globigerinoides ruber. Paleoceanography 23, PA1215.

Sadekov, A., Eggins, S. M., Deckker, P. D., Ninnemann, U., Kuhnt, W., Bassinot, F., 2009. Surface and subsurface seawater temperature reconstruction using $\mathrm{Mg} / \mathrm{Ca}$ microanalysis of planktonic foraminifera Globigerinoides ruber, Globigerinoides sacculifer, and Pulleniatina obliquiloculata. Paleoceanography 24, PA3201.

Sandberg, P. A., 1983. An oscillating trend in Phanerozoic non-skeletal carbonate mineralogy. Nature 305, 19-22.

Schouten, S., Forster, A., Panoto, F. E., Sinninghe Damsté, J. S., 2007. Towards calibration of the $\mathrm{TEX}_{86}$ palaeothermometer for tropical sea surface temperatures in ancient greenhouse worlds. Organic Geochemistry 38, 15371546.

Schouten, S., Hopmans, E. C., Forster, A., van Breugel, Y., Kuypers, M. M. M., Sinninghe Damsté, J., 2003. Extremely high sea-surface temperatures at low latitudes during the middle Cretaceous as revealed by archaeal membrane lipids. Geology 31, 1069.

Schouten, S., Hopmans, E. C., Pancost, R. D., Damsté, J. S. S., 2000. Widespread occurrence of structurally diverse tetraether membrane lipids: Evidence for the ubiquitous presence of low-temperature relatives of hyperthermophiles. Proceedings of the National Academy of Sciences of the United States of America 97, 14421-14426.

Schouten, S., Hopmans, E. C., Schefuß, E., Sinninghe Damsté, J. S., 2002.

Distributional variations in marine crenarchaeotal membrane lipids: a new tool for reconstructing ancient sea water temperatures? Earth and Planetary Science Letters 204, 265-274.

Schrag, D. P., 1999. Effects of diagenesis on the isotopic record of late Paleogene tropical sea surface temperatures. Chemical Geology 161, 215-224.

Schulte, P., Alegret, L., Arenillas, I., Arz, J. A., Barton, P. J., Bown, P. R., Bralower, T. J., Christeson, G. L., Claeys, P., Cockell, C. S., Collins, G. S., Deutsch, A., 
Goldin, T. J., Goto, K., Grajales-Nishimura, J. M., Grieve, R. A. F., Gulick, S. P. S., Johnson, K. R., Kiessling, W., Koeberl, C., Kring, D. A., MacLeod, K. G., Matsui, T., Melosh, J., Montanari, A., Morgan, J. V., Neal, C. R., Nichols, D. J., Norris, R. D., Pierazzo, E., Ravizza, G., Rebolledo-Vieyra, M., Reimold, W. U., Robin, E., Salge, T., Speijer, R. P., Sweet, A. R., Urrutia-Fucugauchi, J., Vajda, V., Whalen, M. T., Willumsen, P. S., 2010. The Chicxulub asteroid Impact and mass extinction at the Cretaceous-Paleogene boundary. Science 327, 1214-1218.

Sexton, P. F., Wilson, P. A., Pearson, P. N., 2006. Microstructural and geochemical perspectives on planktic foraminiferal preservation: "Glassy" versus "Frosty". Geochemistry Geophysics Geosystems 7, Q12P19.

Shackleton, N., Boersma, A., 1981. The climate of the Eocene ocean. Journal of the Geological Society 138, 153-157.

Shackleton, N., Kennett, J. P., 1975. Paleotemperature history of the Cenozoic and the initiation of Antarctic glaciation: Oxygen and carbon isotope analyses in DSDP sites 277, 279, and 281. Initial Reports of the Deep Sea Drilling Project 29, 743.

Sharp, Z. D., 2007. Principles of Stable Isotope Geochemistry. Prentice Hall, New Jersey p. 344.

Siegenthaler, U., Stocker, T. F., Monnin, E., Luthi, D., Schwander, J., Stauffer, B., Raynaud, D., Barnola, J., Fischer, H., Masson-Delmotte, V., Jouzel, J., 2005. Stable carbon cycle-climate relationship during the Late Pleistocene. Science 310, 1313-1317.

Sinninghe Damsté, J. S., Strous, M., Rijpstra, W. I. C., Hopmans, E. C., Geenevasen, J. A. J., van Duin, A. C. T., van Niftrik, L. A., Jetten, M. S. M., 2002. Linearly concatenated cyclobutane lipids form a dense bacterial membrane. Nature 419, 708-712.

Sluijs, A., Schouten, S., Pagani, M., Woltering, M., Brinkhuis, H., Damsté, J. S. S., Dickens, G. R., Huber, M., Reichart, G., Stein, R., Matthiessen, J., Lourens, L. J., Pedentchouk, N., Backman, J., Moran, K., the Expedition 302 Scientists, 2006. Subtropical Arctic Ocean temperatures during the Palaeocene/Eocene thermal maximum. Nature 441, 610-613.

Spahni, R., Chappellaz, J., Stocker, T. F., Loulergue, L., Hausammann, G., Kawamura, K., Fluckiger, J., Schwander, J., Raynaud, D., Masson-Delmotte, V., Jouzel, J., 2005. Atmospheric methane and nitrous oxide of the Late Pleistocene from Antarctic ice cores. Science 310, 1317-1321.

Speelman, E. N., Van Kempen, M. M. L., Barke, J., Brinkhuis, H., Reichart, G. J., Smolders, A. J. P., Roelofs, J. G. M., Sangiorgi, F., de Leeuw, J. W., Lotter, A. F., Sinninghe Damsté, J. S., 2009. The Eocene Arctic Azolla bloom: environmental conditions, productivity and carbon drawdown. Geobiology 7 , 155-170.

Speer, J. A., 1983. Crystal chemistry and phase relations of orthorhombic carbonates. 
Reviews in Mineralogy and Geochemistry 11, 145-190.

Spero, H. J., Bijma, J., Lea, D. W., Bemis, B. E., 1997. Effect of seawater carbonate concentration on foraminiferal carbon and oxygen isotopes. Nature 390, 497500 .

Stanley, S. M., Hardie, L. A., 1998. Secular oscillations in the carbonate mineralogy of reef-building and sediment-producing organisms driven by tectonically forced shifts in seawater chemistry. Palaeogeography Palaeoclimatology Palaeoecology 144, 3-19.

Steuber, T., Veizer, J., 2002. Phanerozoic record of plate tectonic control of seawater chemistry and carbonate sedimentation. Geology 30, 1123-1126.

Tjalma, R. C., Lohmann, G. P., 1983. Paleocene-Eocene bathyal and abyssal benthic foraminifera from the Atlantic Ocean. Micropaleontology Special Publication 4, 90.

Toyofuku, T., Kitazato, H., Kawahata, H., Tsuchiya, M., Nohara, M., 2000. Evaluation of $\mathrm{Mg} / \mathrm{Ca}$ thermometry in foraminifera: Comparison of experimental results and measurements in nature. Paleoceanography 15, 456-464.

Tripati, A., Backman, J., Elderfield, H., Ferretti, P., 2005. Eocene bipolar glaciation associated with global carbon cycle changes. Nature 436, 341-346.

Tripati, A., Elderfield, H., 2005. Deep-Sea temperature and circulation changes at the Paleocene-Eocene Thermal Maximum. Science 308, 1894-1898.

Tripati, A. K., Delaney, M. L., Zachos, J. C., Anderson, L. D., Kelly, D. C., Elderfield, H., 2003. Tropical sea-surface temperature reconstruction for the early Paleogene using $\mathrm{Mg} / \mathrm{Ca}$ ratios of planktonic foraminifera. Paleoceanography 18, 1101.

Tripati, A. K., Elderfield, H., 2004. Abrupt hydrographic changes in the equatorial Pacific and subtropical Atlantic from foraminiferal $\mathrm{Mg} / \mathrm{Ca}$ indicate greenhouse origin for the thermal maximum at the Paleocene-Eocene Boundary. Geochemistry Geophysics Geosystems 5, Q02006.

Urey, H. C., 1947. The thermodynamic properties of isotopic substances. Journal of the Chemical Society (Resumed) 562-581.

Van Der Burgh, J., Visscher, H., Dilcher, D. L., Kurschner, W. M., 1993.

Paleoatmospheric signatures in Neogene fossil leaves. Science 260, 1788-1790.

Wagner, G., 1997. Azolla: A review of its biology and utilization. The Botanical Review 63, 1-26.

Wei, G., Laing, Z., Wen-Feng, D., Xian-Hua, L., Ying, L., Jian-Feng, C., 2009. Mn/Ca ratio in planktonic foraminifer from ODP Site 1144, the northern South China Sea: A possible paleoclimate indicator. Geochemical Journal 43, 235-246. 
Weldeab, S., Schneider, R. R., Kölling, M., 2006. Comparison of foraminiferal cleaning procedures for $\mathrm{Mg} / \mathrm{Ca}$ paleothermometry on core material deposited under varying terrigenous-input and bottom water conditions. Geochemistry Geophysics Geosystems 7, Q04P12.

Wilkinson, B. H., Algeo, T. J., 1989. Sedimentary carbonate record of calcium magnesium cycling. American Journal of Science 289, 1158-1194.

Wilson, D. D., 1956. The Late Cretaceous and Early Tertiary transgression in South Island New Zealand. New Zealand Journal of Science and Technology 37, 610622.

Wilson, D. D., 1963. Geology of the Waipara subdivision. New Zealand Geological Survey Bulletin 64.

Wilson, P. A., Norris, R. D., 2001. Warm tropical ocean surface and global anoxia during the mid-Cretaceous period. Nature 412, 425-429.

Wuchter, C., Schouten, S., Coolen, M. J. L., Sinninghe Damsté, J., 2004. Temperaturedependent variation in the distribution of tetraether membrane lipids of marine Crenarchaeota: Implications for TEX 86 paleothermometry. Paleoceanography 19,4028 .

Zachos, J. C., Schouten, S., Bohaty, S., Quattlebaum, T., Sluijs, A., Brinkhuis, H., Gibbs, S. J., Bralower, T. J., 2006. Extreme warming of mid-latitude coastal ocean during the Paleocene-Eocene Thermal Maximum: Inferences from TEX $\mathrm{T}_{86}$ and isotope data. Geology 34, 737.

Zachos, J., Pagani, M., Sloan, L., Thomas, E., Billups, K., 2001. Trends, rhythms, and aberrations in global climate 65 Ma to present. Science 292, 686-693.

Zachos, J. C., Dickens, G. R., Zeebe, R. E., 2008. An early Cenozoic perspective on greenhouse warming and carbon-cycle dynamics. Nature 451, 279-283.

Zachos, J. C., Kump, L. R., 2005. Carbon cycle feedbacks and the initiation of Antarctic glaciation in the earliest Oligocene. Global and Planetary Change 47, 51-66.

Zachos, J. C., Quinn, T. M., Salamy, K. A., 1996. High-resolution (104 years) deep-sea foraminiferal stable isotope records of the Eocene-Oligocene climate transition. Paleoceanography 11, 251-266.

Zachos, J. C., Stott, L. D., Lohmann, K. C., 1994. Evolution of early Cenozoic marine temperatures. Paleoceanography 9, 353-387.

Zachos, J. C., Wara, M. W., Bohaty, S., Delaney, M. L., Petrizzo, M. R., Brill, A., Bralower, T. J., Premoli-Silva, I., 2003. A transient rise in tropical sea surface temperature during the Paleocene-Eocene Thermal Maximum. Science 302, $1551-1554$. 
Zimmermann, H., 2000. Tertiary seawater chemistry - Implications from primary fluid inclusions in marine halite. American Journal of Science 300, 723-767. 


\section{APPENDICES}

Two appendices accompany this thesis, comprising a detailed list of samples and additional information regarding the mid-Waipara section (Appendix 1), and tables of LA-ICP-MS trace element data accompanied by the full set of laser ablation depth profiles and images of the respective foraminifera (Appendix 2). These appendices are included in digital form on a compact disc attached to the main body of the thesis. 